OCCASIONAL PAPER

\title{
The context of REDD+ in Vietnam
}

\section{Drivers, agents and institutions}

Pham Thu Thuy

Moira Moeliono

Nguyen Thi Hien

Nguyen Huu Tho

vu Thi Hien 

OCCASIONAL PAPER 75

\title{
The context of REDD+ in Vietnam
}

\section{Drivers, agents and institutions}

\author{
Pham Thu Thuy \\ Center for International Forestry Research (CIFOR) \\ Moira Moeliono \\ Center for International Forestry Research (CIFOR) \\ Nguyen Thi Hien \\ Central Institute for Economic Management (CIEM) \\ Nguyen Huu Tho \\ Central Institute for Economic Management (CIEM) \\ Vu Thi Hien \\ Centre of Research and Development in Upland Area (CERDA)
}


Occasional Paper 75

(c) 2012 Center for International Forestry Research All rights reserved

ISBN 978-602-8693-77-6

Pham,T.T., Moeliono, M., Nguyen,T.H., Nguyen, H.T., Vu, T.H. 2012. The context of REDD+ in Vietnam: Drivers, agents and institutions. Occasional Paper 75. CIFOR, Bogor, Indonesia.

\title{
Cover photo: Luke Preece
}

\author{
CIFOR \\ Jl. CIFOR, Situ Gede \\ Bogor Barat 16115 \\ Indonesia \\ $\mathrm{T}+62(251) 8622-622$ \\ $\mathrm{F}+62$ (251) 8622-100 \\ E cifor@cgiar.org
}

\section{www.cifor.org}

Any views expressed in this publication are those of the authors. They do not necessarily represent the views of CIFOR, the authors' institutions or the financial sponsors of this publication. 


\section{Table of contents}

List of figures and tables $\quad$ iv

Abbreviations vi

Acknowledgements viii

Executive summary ix

Introduction $\quad$ xii

1 Drivers of deforestation and forest degradation in Vietnam 1

1.1 Forest area and cover in Vietnam 1

1.2 Key drivers of deforestation and forest degradation in Vietnam 6

2 Institutional environment and distributional aspects $\quad 13$

\begin{tabular}{ll}
2.1 & Governance of forests in Vietnam \\
\hline
\end{tabular}

2.2 Decentralisation 20

2.3 Forest land tenure and ethnic minorities' rights to forests, land and carbon $\quad 24$

3 Political and economic context of deforestation and forest degradation in Vietnam 31

3.1 Historical overview of Vietnam's political system 31

3.2 Decision-making processes and operation of government organisations 36

$\begin{array}{lll}3.3 & \text { National strategy for socio-economic development } & 37\end{array}$

$4 \quad$ The REDD+ policy environment $\quad 44$

4.1 Global policies related to climate change 44

4.2 REDD+ policy actors, events and processes in Vietnam 45

4.3 Implications of REDD+ in Vietnam 50

4.4 Measurement, reporting and verification (MRV) 52

5 The 3Es and REDD+ implementation in Vietnam 59

5.1 Deforestation and forest degradation policies $\quad 59$

$\begin{array}{ll}5.2 & \text { Measurement, reporting and verification }\end{array}$

5.3 Institutional arrangements, coordination and commitment 64

$\begin{array}{lll}5.4 & \text { Equity } & 64\end{array}$

$\begin{array}{lll}6 & \text { Conclusions and recommendations } & 67\end{array}$

7 References $\quad 70$

$\begin{array}{ll}\text { Laws and regulations cited } & 78\end{array}$ 


\section{List of figures and tables}

Figures

1.1 Forest cover in Vietnam, 2010

1.2 Area of forest in Vietnam, 1943-2009, by forest type 3

1.3 Extent of change in forest cover in Vietnam, 1943-2009 3

1.4 Correlation between poverty incidence and forest cover in Vietnam 5

1.5 Correlation between poverty rate, forest cover and population density in Vietnam 6

1.6 Conversion of forest land in Vietnam, 2003-2009 8

$\begin{array}{lll}1.7 & \text { Areas of mangroves and shrimp farms in Vietnam } & 8\end{array}$

1.8 Area of forest logged (ha), 2002-2009 9

1.9 Area of forest in Vietnam destroyed by fire, 2002-2010 10

2.1 Vietnam's Forestry Development Strategy 15

$\begin{array}{ll}2.2 & \text { Funding sources for 5MHRP } \\ & 19\end{array}$

2.3 The forest extension services system in Vietnam 22

$\begin{array}{lll}2.4 & \text { REDD+ value chain } & 28\end{array}$

3.1 Overview of economic and political developments since the Vietnam War 32

3.2 Vietnam's GDP, 1990-2009 34

3.3 Population of Vietnam 35

3.4 Government planning system for environmental activities in Vietnam 36

4.1 Timeline of Vietnam's main policies related to climate change and REDD+ 47

4.2 Institutional arrangement for REDD+ implementation in Vietnam 48

4.3 Average land cover carbon density in 2000 by province and district 57

4.4 Land cover carbon density in Vietnam, $2000 \quad 57$

4.5 Trends in carbon stock in living forest biomass in Vietnam, 1990-2010 58

\section{Tables}

1.1 Forest composition in Vietnam, 2009, by type and use category 4

1.2 Ten most forested provinces in Vietnam as of $2009 \quad 4$

$\begin{array}{lll}1.3 & \text { Increase-decrease in forest area in Vietnam, 2004-2008 } & 7\end{array}$

1.4 The impact of national development policies on forests in Vietnam 11

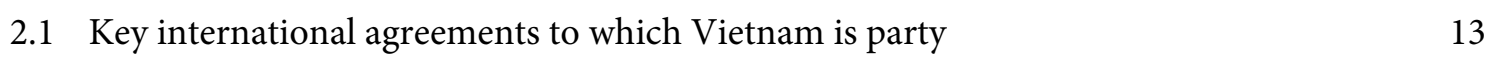

2.2 Strengths and weaknesses of Vietnam's forest policies 18

2.3 State management system for forest resources and forest land in Vietnam 20

2.4 Restructuring of state-owned enterprises in Vietnam 23 
2.5 Key pieces of Vietnamese legislation on land use and taxation

3.1 Plantation and export of coffee and rubber in Vietnam, 1995-2009 39

3.2 Export value of timber products from Vietnam to major markets, 2006-2009 41

3.3 Forecasts for industrial consumption of Vietnam's timber products 41

3.4 Production and export value of forest products from Vietnam, 2001-2009 42

4.1 Institutional arrangements for the National REDD+ Programme 49

4.2 Perceived advantages and disadvantages of financial options for REDD+ 50

4.3 Vietnam's four rounds of forest inventory $\quad 54$

4.4 Stakeholders and their activities in MRV in Vietnam 54

4.5 Comparison of two land use classification systems operating in Vietnam 55

4.6 Areas of forest-related land use categories according to GDLA and FPD data, 2005 and 2007 


\section{Abbreviations}

5MHRP Five Million Hectare Reforestation Programme

ADB Asian Development Bank

AFTA ASEAN Free Trade Area

APEC Asia Pacific Economic Cooperation

AR-CDM Afforestation and Reforestation-Clean Development Mechanism

BDS

CBD

CDM

CER

Benefit Distribution System

CERDA

CIEM

CIFOR

CITES

CNECB

$\mathrm{CPC}$

CSO

DARD

DNA

DoF

DoFP

DPC

FAO

FCPF

FDI

FIPI

FLA

Convention on Biological Diversity

Clean Development Mechanism

Certified Emission Reduction

Centre for Research and Development in Upland Areas

Central Institute for Economic Management

Center for International Forestry Research

Convention on International Trade in Endangered Species of Wild Fauna and Flora

CDM National Executive and Consultative Board

Commune People's Committee

civil society organisation

Department of Agriculture and Rural Development

Designated National Authority

Department of Forestry

Department of Forest Protection

District People's Committees

Food and Agriculture Organization of the United Nations

Forest Carbon Partnership Facility

Foreign direct investment

Forest Inventory and Planning Institute

FLEGT Forest Law Enforcement, Governance and Trade

FORMIS Forest Sector Management Information System

FPD Forest Protection Department

FPIC Free, Prior, and Informed Consent

FSC Forest Stewardship Council

FSSP Forest Sector Support Programme

GAMA Globally Appropriate Mitigation Action

GDLA General Department of Land Administration

GDOF General Department of Forestry

GMS Greater Mekong Subregion

GSO General Statistics Office

ICRAF World Agroforestry Centre

IMF International Monetary Fund

IUCN International Union for the Conservation of Nature

LAAMA Locally Appropriate Adaptation and Mitigation Action

LURC Land Use Right Certificate

MARD Ministry of Agriculture and Rural Development

MoFi Ministry of Finance

MONRE Ministry of Natural Resources and Environment

MPI

Ministry of Planning and Investment 


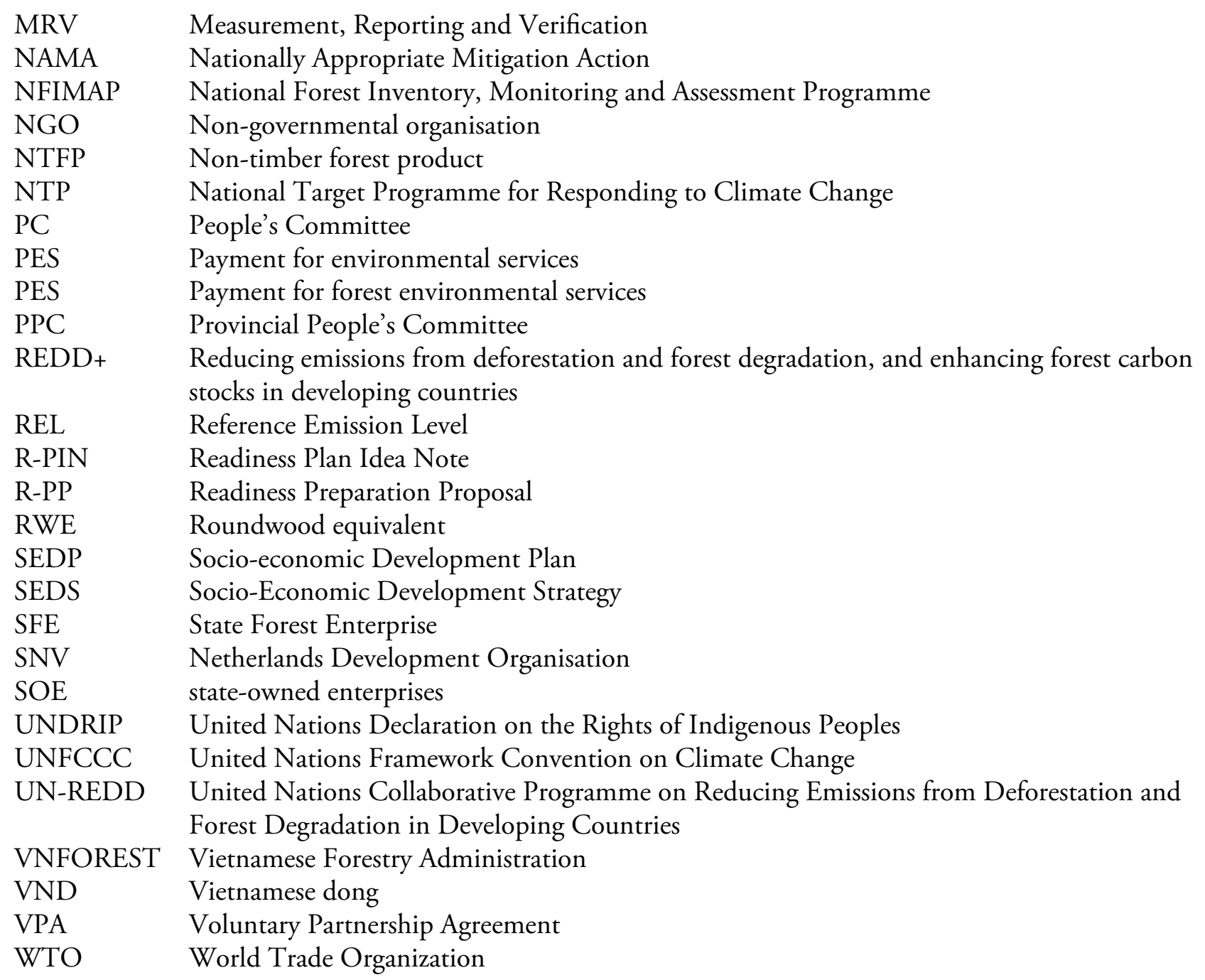




\section{Acknowledgements}

This country profile grew over a period of 2 years, and it could not have been done without the support of many others. It is based on CIFOR's Global Comparative Study (GCS) Component 1 methodological framework and the country profile guidelines (Brockhaus et al. 2010). The research for this report was conducted from February 2010 until August 2011, with the research for this report was conducted from February 2010 until August 2011, with final revisions taking place in February 2012. The different levels of interest, capacity and understanding of REDD+ of the authors, brought both joy and challenges to the report writing process. Moreover, the rapid movement of REDD discussion in Vietnam, featuring some new issues almost every month made it difficult for the authors to capture all the key events timely and comprehensively. Therefore, this report should be seen as a "living document" which can always be updated based on the background information presented in its original forms.

The report could also not have been written without the support of the Central Institute for Economic Management (CIEM), Centre of Research and Development in Upland Area (CERDA) and the The World Agroforesty Centre (ICRAF). Special thanks are due to Hoang Minh Ha who played an essential role in facilitating the set-up for this study in Vietnam. We are very grateful to a number of external and internal peer reviewers, especially Pham Minh Thoa (Ministry of Agriculture and Rural
Development), Vu Xuan Nguyen Hong (Ministry of Planning and Investment), Vu Tan Phuong at the Research Centre for Forest Ecology and Environment (RCFEE) in Vietnam, Tim Boyle (UN-REDD) and Thomas Sikor (University of East Anglia). Without their contributions and critical comments this document would not have been possible. During the long process of writing and revising we benefitted enormously from discussions with amongst others Maria Brockhaus, Cecilia Luttrell, Christine Padoch, and many others at CIFOR, as well as the input provided by a series of reviewers and participants at the national workshop during which the first draft of this report was discussed. We greatly appreciate all their help and thank them all. We would also like to thank a number of anonymous respondents from government, research and donor agencies, NGOs and the private sector. We are also grateful to Edith Johnson, Imogen Badgery-Parker and Catriona Moss for their valuable roles in editing this document and Le Ngoc Dung for logistical support in arranging this study.

The authors gratefully acknowledge the support received from the Norwegian Agency for Development Cooperation, the Australian Agency for International Development, the UK Department for International Development, the European Commission, and the Department for International Development Cooperation of Finland. 


\section{Executive summary}

Reducing emissions from deforestation and degradation (REDD+) has captured global and national attention because of its potential contribution to climate change mitigation; at the same time, translating the concept from the international to the national policy arena is highly complex. As a country likely to be seriously affected by climate change, Vietnam has engaged deeply in international discussions and preparations to implement REDD+. Furthermore, Vietnam has been selected as one of the first countries to pilot the United Nations REDD (UN-REDD) programme and practise Free, Prior and Informed Consent (FPIC), which is the principle that a community has the right to give or withhold its consent to proposed projects that may affect the lands they customarily own, occupy or otherwise use. Vietnam provides an interesting example for several other reasons. First, Vietnam is at the end of the so-called forest transition curve, which describes the state of a country's or region's forest as it moves from high rates of deforestation to regrowth of a stable and expanding forest cover, as correlated to economic development. That forest in Vietnam has been identified as being at the end of this curve means that the country's forest cover is increasing, but with declining forest quality. This feature raises questions as to whether Vietnam will be able to benefit from REDD+ and carbon market in the long run. Second, in contrast to other countries, in Vietnam REDD+ is seen as a potential source of income that can contribute both to the national payments for environmental services (PES) programme and to the national poverty reduction strategy. This presents an interesting case of how REDD+ can potentially contribute to domestic policies and revenue and of the trade-offs required. Third, the country's strong leadership and the fact that the state manages all land can be used to examine how REDD+ might work in an authoritarian system of governance.

As part of the Global Comparative Study (GSC) on REDD+, a project carried out by CIFOR with financial support from Norad, this report aims to discuss the political, economic and social opportunities and constraints that will affect the design and implementation of REDD+ in Vietnam. The report begins by identifying the drivers of deforestation and degradation in Vietnam, and then analyses aspects of the social, political and institutional context that might constrain or support the design and implementation of REDD+ in Vietnam. For this study, for the first time in Vietnam, a government agency (Central Institute for Economic Management within the Ministry of Planning and Investment (MPI), responsible for national sectoral and budget planning), a local civil society organisation (CERDA) and an international organisation (CIFOR) collaborated in producing this report. The involvement of the MPI ensured a broader perspective on the assessment of REDD+, including an examination of both macro and microeconomics and policies in Vietnam, rather than a more limited examination of forestry sector planning and policies only. The involvement of CERDA, which offered a grassroots perspective, added a new dimension in the approach to observing and implementing REDD+.

For comparative reasons, the report largely follows the report template of the GSC project, with some modifications. The content benefited from a rich literature review of policy studies and reports conducted by government agencies, international and national non-governmental organisations (NGOs) and donors. Additional information was obtained through 50 interviews, conducted in 2010 and 2011, with representatives from government agencies (at national, provincial, district, commune and village levels), international and national NGOs and civil society organisations (CSOs). The results then underwent a review process, starting with a national consultation workshop in July 2010 and three rounds of both internal and external review.

The paper identifies four main direct drivers and three main indirect drivers of deforestation and forest degradation in Vietnam. The direct drivers are 1) land conversion for agriculture; 2) infrastructure development; 3) logging (illegal and legal); and 4) forest fire. The indirect drivers 
are 1) the pressure of population growth and migration; 2) the state's weak forest management capacity; and 3) the limited funding available for forest protection. These drivers and their impacts vary from region to region, and change over time; this suggests that no 'one-size-fits-all' formula will function across the whole of Vietnam. Instead, the government needs to determine the main principles and general policy but allow individual programmes to be designed and implemented based on local drivers and socio-economic needs (e.g. infrastructure development, agriculture development, land conversion), while also meeting demand from international markets (e.g. increasing demand for seafood and wood products).

The Vietnamese government has developed various policies and programmes targeting a reduction in deforestation and forest degradation. These include the national reforestation programme, or Programme 661 (also known as 5MHRP); the land allocation programme; the National Forest Development Strategy; and Decision 380 and Decree 99, which aim to enhance payments for forest environmental services. These policies have contributed towards the mitigation of deforestation and forest degradation, as reflected in the net increase in forest cover in Vietnam over time.

However, these initiatives have some shortcomings. First, although forest cover has increased during the past two decades, the quality of the forests has decreased. The area of degraded forest has increased and, even though new forest has been planted, forest density overall has declined. Carbon stocks are therefore lower. This outcome shows that simply increasing the forest area through reforestation is not sufficient to rehabilitate forest ecosystem functions and services, especially with regard to carbon stock. This poses a serious challenge both for biodiversity conservation and for the role of forests in providing services as carbon sinks to mitigate climate change.

Second, in the past, practical implementation of well-intended policies has been characterised by numerous failures and weaknesses. Many policy measures are compromised by limited funding for forest protection, weak local governance capacity, poor vertical and horizontal coordination, low involvement of the poor, women and indigenous groups, low economic returns, elite capture of land and benefits, and corruption. Despite widespread awareness of these issues and concerted efforts by government and donors to address them, effective solutions are yet to be found.

Third, many development policies have not been scrutinised in terms of their potential unintended effects. That is, a policy released to address one problem may in fact end up causing another problem. For example, in addressing the problem of unequal population distribution - partly a legacy of colonialism - the relocation policy led to increasing deforestation in resettlement areas.

Fourth, while several policies related to REDD+ have been released and are currently being piloted across the country, REDD+ policy needs improvement in two main areas: 1) provisions for benefit sharing and PES; and 2) procedures for assessment, approval and provision of carbon rights. Improvement in these areas requires careful analysis of Vietnam's existing institutions, as well as the projected future demand-and-supply curve of international and national carbon markets. It is also important to acknowledge that drivers of deforestation and degradation in Vietnam differ across space and time. As the analysis in this study highlights, the main causes of deforestation and forest degradation - land conversion and poor governance - are difficult to tackle.

This report uses the 3Es (effective, efficient and equity) as a lens through which to assess future REDD+ policy and implementation in Vietnam. The findings indicate that, of these, equity receives the most attention in government policies, followed by efficiency and then effectiveness. As great hopes are being pinned on REDD+'s potential contribution to poverty reduction, the design of a national benefit-sharing mechanism is a key focus in Vietnam. Policymakers have analysed and considered two possible pathways for sharing benefits. The first option is to use the existing national Forest Protection and Development Fund, with modifications as necessary. The second pathway is to establish a new mechanism, as required by the international community. The two options, which are to be assessed mainly against pro-poor, equity and efficiency criteria, are currently being circulated to obtain comments and feedback from stakeholders across the country. However, our research has uncovered three major 
barriers to REDD+ implementation in Vietnam: the uncertainty of the REDD+ market; potential conflicts with the private sector incited by the top-down approach; and the success of domestic PES policies compared with the uncertainty of a REDD+ market leading to local people's reluctance to participate. Moreover, voices at the grassroots level are limited, as are those of vulnerable groups including women, the poor and indigenous groups, in all processes related to REDD+.

The research suggests that, if REDD+ is to succeed, it must be: participatory, that is, all players are given fair and ample opportunity to take part in the programme (particularly those with the least resources or the greatest economic disenfranchisement); transparent, that is, all players can trace how the programme is administered, including the distribution of benefits; and wellmonitored, to ensure that the programme is conducted such that it meets its overarching objectives and guidelines. The success of REDD+ will also depend on it taking a pro-poor and pro-gender equity approach. While the issue of migration appears to have been overlooked in previous programmes as well as in REDD+, the study identifies a need to better address this issue in the future. 


\section{Introduction}

\begin{abstract}
A $s$ global interest in addressing climate change has grown, so too has the attention directed towards the large impact on climate wrought by processes of deforestation and forest degradation. This has led to the development of a new approach towards mitigating climate change that uses economic incentive structures and a target of 'reducing' rather than 'ending' emissions in a cost-effective manner, the so-called 'Reducing Emissions from Deforestation and forest Degradation' (REDD) mechanism. The idea was introduced at the 2007 United Nations Framework Convention on Climate Change (UNFCCC) Conference of the Parties (COP 13) in Bali, and further developed into 'REDD+' with the addition of the goals of 'sustainable forest management', 'conservation' and 'increasing forest carbon stocks'.
\end{abstract}

However, whether REDD+ does actually have the potential to mitigate climate change can only be proved by solid science and the use of living, global examples. Therefore, CIFOR is implementing a four-year research project known as the Global Comparative Study (GCS) on REDD+. The study is being carried out in 12 countries with the aim of providing policymakers and practitioner communities with the information, analysis and methods needed to ensure effective, cost-efficient and equitable reduction of carbon emissions as well as co-benefits, known as the $3 \mathrm{E}+$ criteria. $^{1}$

Vietnam, one of the 12 countries studied has five main characteristics which can provide important lessons on how REDD+ might be implemented in developing countries. First, the country, characterised by a long coastline and natural resources already under pressure, is one of the most vulnerable to climate change (Hoang et al. 2010, World Bank 2010). Second, Vietnam is one of the few tropical countries located towards the right-hand end of the forest transition curve, that is, forest cover in Vietnam is actually increasing

1 For more information on the Global Comparative Study, see http://www.forestsclimatechange.org/global-comparativestudy-on-redd.html. (de Jong et al. 2006, Meyfroidt and Lambin 2009, Hoang et al. 2010). However, even though total forest cover has increased since 1997, the past decade still saw an alarming extent of degradation of natural forest, continuing a trend underway since the 1940s. Given that carbon stocks in diverse, natural forest are estimated to be 5-10 times higher than those in planted forest, an increase in forest area alone does not guarantee a reduction in emissions (Hoang et al. 2010). Third, Vietnam is the first country in Asia to implement a national programme for payment for forest environmental services (PES). Indeed, REDD+ has been accepted as a component of PES and therefore Vietnam could potentially provide useful lessons on the integration of REDD+ into national policies. Fourth, Vietnam's forestry sector in general, and PES and REDD+ in particular, has the explicitly stated mission of also addressing national poverty reduction. This pro-poor and social objective has a great influence on the design of the REDD+ scheme and can potentially point to useful lessons in relation to the social dimension of REDD+. Finally, Vietnam has been selected as a pilot country in the United Nations Collaborative Program on Reducing Emissions from Deforestation and Forest Degradation in Developing Countries (UN-REDD) and the World Bank's Forest Carbon Partnership Facility (FCPF), which are the world's best-known proponents of REDD+. It should be noted that Vietnam is the most advanced country in these programmes, with the FCPF having accepted its Readiness Plan Idea Note (R-PIN). Vietnam is also the first country to pilot a Free, Prior and Informed Consent (FPIC) programme developed to safeguard the interests of forest communities. The pilot was conducted in Lam Dong province.

Vietnam has thus demonstrated a strong commitment to joining global efforts to combat climate change. However, as in many other developing countries, Vietnam is struggling to balance continuing economic development with environmental and social considerations. As is the case with countries such as Indonesia and Nepal, finding the right balance has not been easy given 
vested interests and entrenched ineffective and inefficient systems

This working paper is an output of the GSC Component 1, whose focus is REDD+ development and implementation in specific countries, in this case Vietnam. The report is divided into eight sections that explore and analyse the factors that are shaping, or will shape, the design and implementation of REDD+ in Vietnam. This introductory chapter sets out the rationale for the study and highlights the importance of understanding the lessons from Vietnam. The second part presents the methods applied in this research. In Chapter 1, we assess Vietnam's forestry sector and identify the drivers of deforestation and degradation and their underlying causes. Chapter 2 analyses the institutional arrangements of the forestry sector, in which any future REDD+ project will be embedded. This analysis provides the necessary background for understanding the opportunities and constraints that will affect REDD+ in the future. Chapter 3 presents the political economy context needed to understand the factors that might help or hinder the design and implementation of REDD+. Chapter 4 analyses the current institutional and organisational arrangements for REDD+, and Chapter 5 employs the efficiency, effectiveness and equity criteria (the ' $3 \mathrm{Es}$ ') as a lens through which to assess potential REDD+ options for Vietnam. The final chapter offers short-term and long-term suggestions for ways to make REDD+ feasible, both in Vietnam in particular and in developing countries in general.

This study was initiated in February 2010 with the aim of providing the national partners that play an important role in facilitating REDD+ with essential, up-to-date information. However, difficulties in collecting information and analysing the results meant the report took about two years to complete. Furthermore, with the debate on REDD+ in Vietnam shifting frequently and rapidly, the related information requires continuous updating. Therefore, this report, while providing a solid foundation of the relevant context, must be seen as a 'living document', which can be updated as necessary.

\section{Methods}

The study upon which this report is based adopted a wide range of methods, as described below.

Literature review: Publications from a range of sources including government, international donors and agencies, and non-governmental organisation (NGO) reports, studies and research were reviewed and analysed to identify and understand the opportunities and constraints affecting REDD+ uptake in Vietnam. It should be noted that rapid changes and progress in Vietnam policies and programmes related to REDD+ made it difficult for the team to capture all activities and policies.

Policy content analysis: An analysis of the origins, intentions and implementation of policies was conducted to understand the national orientation and strategies for REDD+, as well as the legal opportunities and barriers influencing the operation of REDD+ in Vietnam.

In-depth interviews: More than 50 in-depth interviews were conducted with representatives of government agencies, donors, international and national NGOs, research institutes and civil society organisations (CSOs) in 2010 and 2011, with the aim of exploring stakeholders' perceptions and experiences in relation to the opportunities and constraints affecting REDD+ in Vietnam.

Observation: REDD+ is new not only to the international community but also to national policymakers, and the process of its formulation has been very rapid and heavily driven by international discussion. Many of the important events and discussions were not captured in earlier discussions and reports. The authors, who have engaged in the national REDD+ process during the past few years, used their own observations in reflecting on the process and its critical milestones.

National consultation process: At a consultation workshop (Hanoi, 23 July 2010), 25 participants from government agencies, international and local NGOs and donors contributed their thoughts and comments for the improvement of report. 
Expert peer review: To ensure the accuracy of the results, the report was first reviewed by three national experts (the national director of the UNREDD+ programme, the Forest Science Institute of Vietnam and the Ministry of Planning and Investment). The team revised the report based on the valuable feedback, before presenting it at the national consultation workshop to obtain a wider range of comments from various stakeholders. The report was then revised and reviewed by three external reviewers (two international experts who have worked in forest programmes in Vietnam for more than 15 years and a national expert who has been closely involved in the development of the forestry sector for the past 12 years) for further comments. 


\section{Drivers of deforestation and forest degradation in Vietnam}

$\mathrm{V}$ ietnam is highly vulnerable to the impacts of climate change due to the combination of its geographical characteristics coastal location, low-lying river deltas, steep mountain ranges - and an economy dependent on agricultural production (RECOFTC, ASFN and SDC 2011). Recognising this vulnerability and the need to cope with the impacts of climate change, Vietnam was an early adopter of various policies dealing with climate change in general and with the importance of forests in mitigating climate change in particular. This chapter presents an overview of the status of forests in Vietnam and forest governance. Also discussed are the drivers of deforestation and forest degradation and the underlying causes.

\subsection{Forest area and cover in Vietnam}

The total forest cover in Vietnam in 2010 was 13797000 ha or $44 \%$ of the total land area (FAO 2010).

As mentioned, Vietnam is one of the few countries in Asia that have had a net increase in forest cover, thus it is classified as being in the fourth stage of the forest transition (de Jong et al. 2006, MARD 2007a, Meyfroidt and Lambin 2008), that is, the point at which forest area is increasing.

In 1943, Vietnam's forests covered 14.3 million ha, or about $43 \%$ of the total land area (de Jong et al. 2006). During the next five decades, serious deforestation occurred and the forest area gradually decreased (see Figures 1.1 and 1.3). By 1990, only 9.175 million ha $(27.8 \%$ of the land area) was left forested (DoFP 2010). The remaining forests consisted largely of degraded natural forests or plantations, with primary natural forest estimated at between $1 \%$ (FAO 2010) and $2 \%$ of the forested area (RECOFTC 2011).

To address deforestation, the government has implemented several reforestation programmes (e.g. Programme 327, National Five Million Hectare Reforestation Program (5MHRP); see Section 2.1.3 in Chapter 2 for details) with the overall objective of reforesting and rehabilitating 5 million ha of forest by 2010 . Forest area increased by 4.1 million ha and by 2009 , Vietnam had 13.258 million ha of forest area $(39.1 \%$ of the total land area) (Figures 1.2 and 1.3). The net increase in forest area can be explained partly by plantation development (Sunderlin and Huynh 2005, de Jong et al. 2006, Meyfroidt and Lambin 2008, Bleaney et al. 2009; Figure 1.1) and partly by the re-categorisation and inclusion of previously omitted limestone forests in the category of forest, as well as natural regeneration, predominantly in bamboo forest areas ( $\mathrm{Vu}$ et al. 2011). In addition, national forest tenure reform, the availability of new technologies, market opportunities for cash crops and the liberalisation of, and increase in, agricultural output have contributed significantly to the increase in forest area (Sikor 2001).

At the same time, however, the total area of natural forest has continued to decline (Figure 1.2). Lowland natural forests, with their richness of natural biodiversity, have been almost entirely lost, while Vietnam's mangrove forests have been 

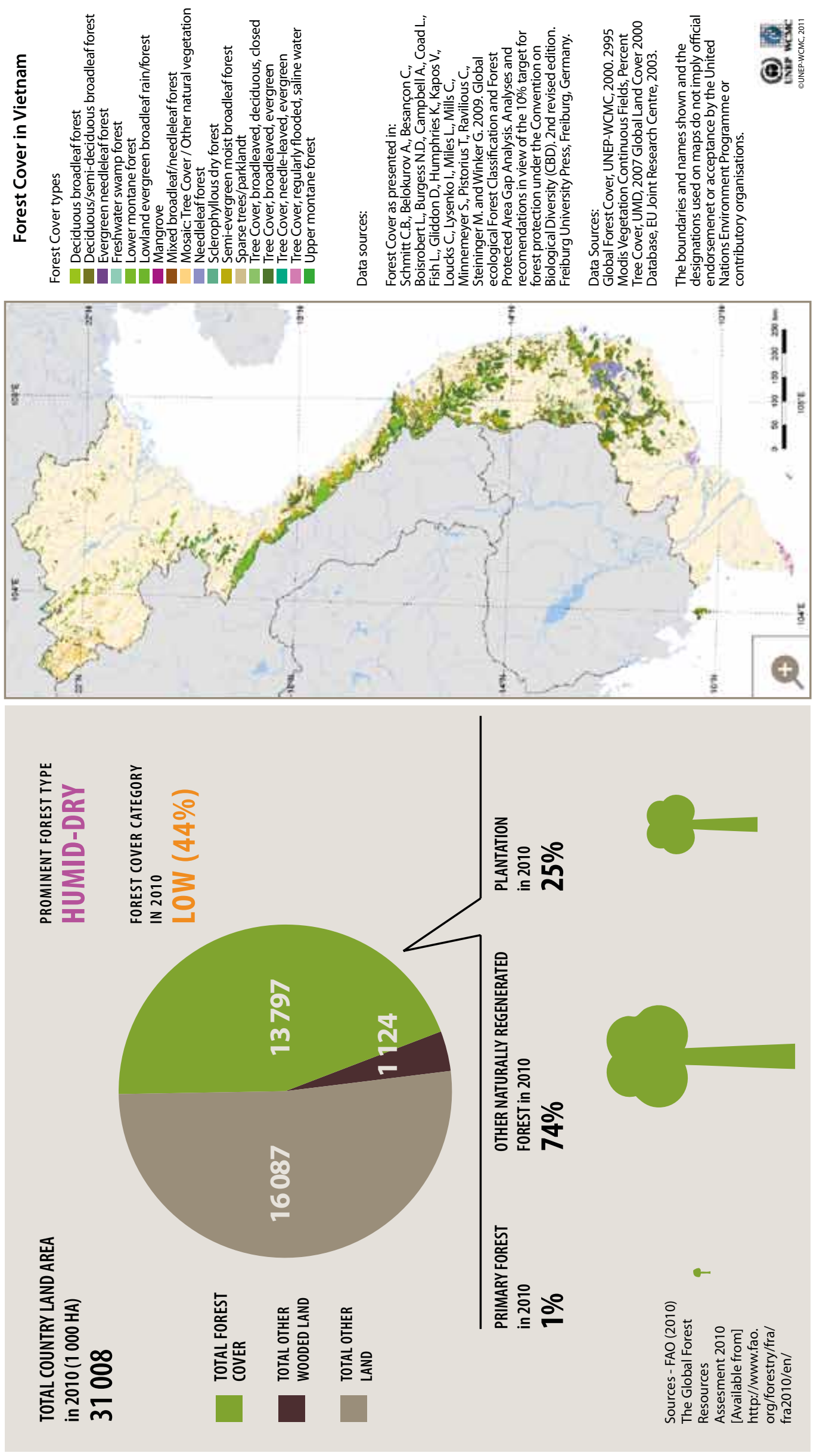

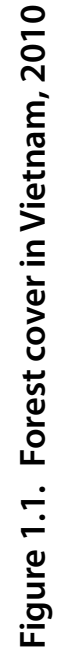




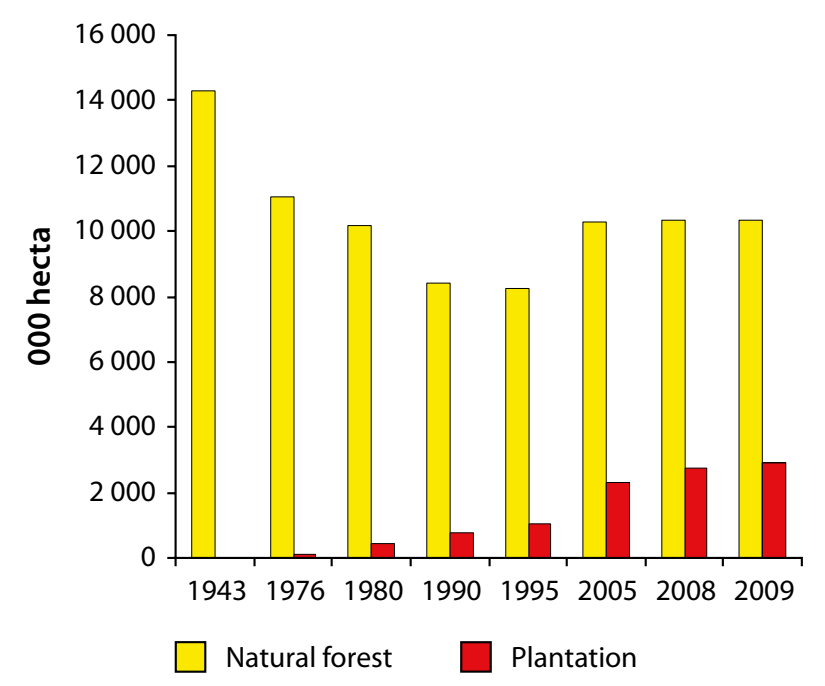

Figure 1.2. Area of forest in Vietnam, 1943-2009, by forest type

Source: Data 1943-1995, de Jong et al. 2006; 2002-2009: DoFP 2010

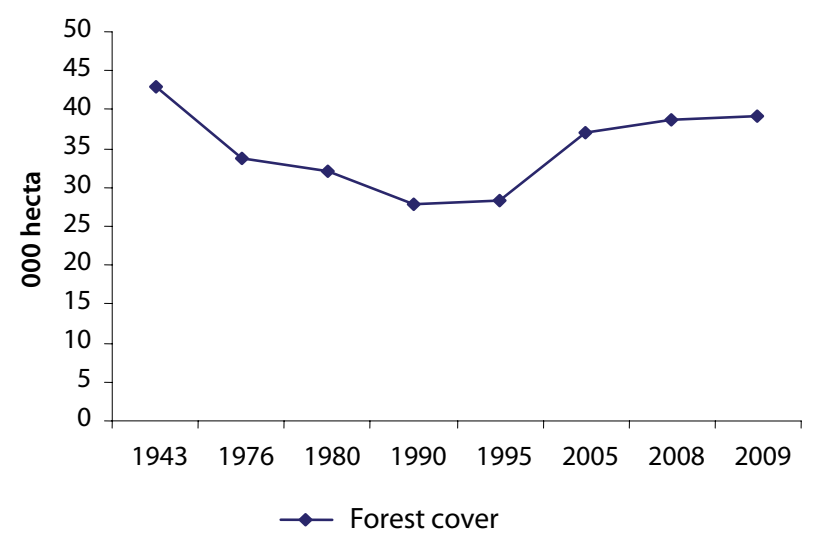

Figure 1.3. Extent of change in forest cover in Vietnam, 1943-2009

Source: Data 1943-1995, de Jong et al. 2006; 2002-2009: DoFP 2010

significantly degraded (Vu et al. 2011). Currently, only about 80000 ha of primary natural forest remains, and even this is under threat (RECOFTC 2011). The remaining forest, which is found largely in the Central Highlands and Southeast regions (de Jong et al. 2006), contains most of the country's carbon stock and is crucial for watershed protection and biodiversity conservation (Bleaney et al. 2009).
Therefore, although reforestation has resulted in increased forest area, the data indicate that most of the forest area consists of monoculture plantations, with the remaining natural forests in poor condition or regenerating; furthermore, the pattern of their fragmentation and degradation is continuing (Meyfroidt and Lambin 2008, Vu et al. 2011). A study by de Jong et al. (2006) showed that poor-quality natural forests, with a forest stock of less than $80 \mathrm{~m}^{3} / \mathrm{ha}$, occupied up to $80 \%$ of the total forest area at that time.

As noted above, by 2009, Vietnam had 13.258 million ha of forest, of which $78 \%$ was natural forest, primarily mixed hardwood (Table 1.1). Plantations (Table 1.1), mostly monocultures of a few tree species such as acacia, eucalyptus, pine and bamboo, with a few cases where indigenous species are planted, make up the remainder.

Vietnam categorises forests by designated use:

1. protection forest, reserved for watershed and soil protection, prevention of erosion and desertification, and environmental preservation;

2. special-use forest, designated mainly for natural area preservation, ecological diversity, germplasm conservation and scientific research; and

3. production forest, used mainly for timber production in combination with watershed and environmental protection. ${ }^{2}$ At the end of 2009, production forest accounted for $47.4 \%$ of Vietnam's total forest land, with protection forest and special-use forest accounting for $36.5 \%$ and $15.1 \%$, respectively (Table 1.1 ).

These forests are unevenly distributed among the provinces, with three of Vietnam's eight regions containing $70 \%$ of the total forest area (both natural and planted): the Northeast (25.4\%); the Central Highlands (22.3\%); and the North Central $(20.5 \%)$. The total area of forest in the 10 most forested provinces is almost equal to that of the other 53 provinces combined (Table 1.2). Similarly, plantations, especially industrial plantations, are unequally distributed; most of

2 Circulation 34/2009/TT-BNNPTNT, 10 June 2009 of MARD. 
Table 1.1. Forest composition in Vietnam, 2009, by type and use category

Unit: ha

\begin{tabular}{|c|c|c|c|c|c|c|}
\hline & \multirow{2}{*}{ Forest Type } & \multirow{2}{*}{ Total $^{a}$} & \multicolumn{4}{|c|}{ By use category } \\
\hline & & & Special use & Protection & Production & Other \\
\hline \multirow[t]{6}{*}{1} & Natural Forest & 10339305 & 1921944 & 4241384 & 4147005 & 28972 \\
\hline & Mixed hardwood & 8235838 & 1477802 & 3381501 & 3358188 & 18346 \\
\hline & Limestone mountain forest & 735779 & 240700 & 408346 & 81150 & 5583 \\
\hline & Mixed forest & 685631 & 129819 & 234694 & 318994 & 2124 \\
\hline & Bamboo & 621454 & 59637 & 177330 & 382402 & 2084 \\
\hline & Mangroves & 60603 & 13986 & 39512 & 6270 & 835 \\
\hline \multirow[t]{7}{*}{2} & Plantation & 2919538 & 77971 & 591578 & 2141241 & 108748 \\
\hline & Stocked forest ${ }^{b}$ & 1464330 & 48761 & 337127 & 1043267 & 35174 \\
\hline & Unstocked forest ${ }^{c}$ & 1124930 & 22218 & 194234 & 865501 & 42978 \\
\hline & Other trees (e.g. Acacia) & 206730 & 3399 & 26360 & 150641 & 26330 \\
\hline & Bamboo & 87829 & 171 & 6227 & 81164 & 266 \\
\hline & Mangroves & 35719 & 3421 & 27630 & 669 & 4000 \\
\hline & Total & 13258843 & 1999915 & 4832962 & 6288246 & 137720 \\
\hline
\end{tabular}

a As of 31 December 2009

b With forest stock: hardwood forest, diameter at breast height $\geq 8 \mathrm{~cm}$, volume $\geq 10 \mathrm{~m}^{3} / \mathrm{ha}$

c Without forest stock: hardwood forest, diameter at breast height $<8 \mathrm{~cm}$, volume $<10 \mathrm{~m}^{3} / \mathrm{ha}$

Source: DoFP 2010

them are concentrated in the Northern Mountains, North Central and South Central, with only a small area in the Eastern Highlands and Red River Delta (de Jong et al. 2006). The Mekong Delta has major plantations of indigenous species such as Rhizophora apiculata and Melaleuca leucadendra. Acacia or eucalypt plantations are scattered across several provinces, developed mainly to supply pulp and chip mills. In addition, rubber is planted because its wood is an important raw material for the wood-processing industry (de Jong et al. 2006).

As in many other forested countries, there is a high incidence of poverty in forest areas (Müller et al. 2006). A study conducted by FAO (2005) supports Müller's finding by highlighting that low poverty incidence tends to accompany low forest cover percentages, as found in both river deltas and partly along the coastline (Figures 1.4 and 1.5).

In the Northern Uplands, Central Vietnam and Central Highlands, where large areas are covered by forest, the poverty incidence is high. This indicates that the livelihoods of the poor are often at the frontline of conservation-development conflicts. In Vietnam, $85 \%$ of protected areas are located in areas of 'medium' and 'high' poverty
Table 1.2. Ten most forested provinces in Vietnam as of 2009

\begin{tabular}{lllc}
\hline \multicolumn{1}{c}{ Province } & $\begin{array}{c}\text { Area } \\
(1 \text { 000 ha })\end{array}$ & $\begin{array}{c}\text { Forest cover } \\
\text { (\%) }\end{array}$ \\
\hline $\begin{array}{lll}\text { Northeast } \\
1\end{array}$ & Son La & 583.5 & 41.2 \\
2 & Ha Giang & 422.5 & 52.6 \\
\hline \multicolumn{2}{l}{ North Central } \\
3 & Nghe An & 807.2 & 47.8 \\
4 & Thanh Hoa & 527.1 & 46.1 \\
5 & Quang Binh & 545.7 & 66.9 \\
6 & Quang Nam & 457.1 & 43.1 \\
\hline Central Highlands & & \\
7 & Gia Lai & 717.4 & 46.0 \\
8 & Kon Tum & 655.9 & 67.3 \\
9 & Dak Lak & 629.0 & 47.2 \\
10 & Lam Dong & 602.8 & 61.2 \\
\hline
\end{tabular}

Source: DoFP 2009, 2010 
(ICEM 2003). This suggests that poverty reduction strategies can help to address deforestation and degradation and vice versa.

Forests have been, and to some degree still are, an important source of revenue for Vietnam. In 2005, the contribution of the forestry sector to GDP was officially estimated at $1 \%(\mathrm{GoV} 2005)$ although Sikor (1998) and de Jong et al. (2006) pointed out that this figure does not include the contribution of the industrial production sector, unrecorded forest product consumption or environmental services. If adding these values, the forestry sector contributes about $2 \%$ of total national revenue; the sector accounted for $10 \%$ of the total national export value for the period 1986-1989, and 6\% of the national industrial production sector (Castrén 1999, de Jong et al. 2006).

Forests and their resources play a vital role in local livelihoods. Vietnam is home to at least 25 million forest-dependent people, who obtain an average of $20 \%$ of their total (monetary and non-monetary) income from forest resources (GoV 2005); a study by Raintree et al. (1999) came up with a figure of $15 \%$, and Mai et al. (1999) put it at 24\%. People in mountainous areas with high poverty rates derive the highest proportion of their income from forest-related activities (GSO 2001, Sunderlin and Huynh 2005, de Jong et al. 2006).
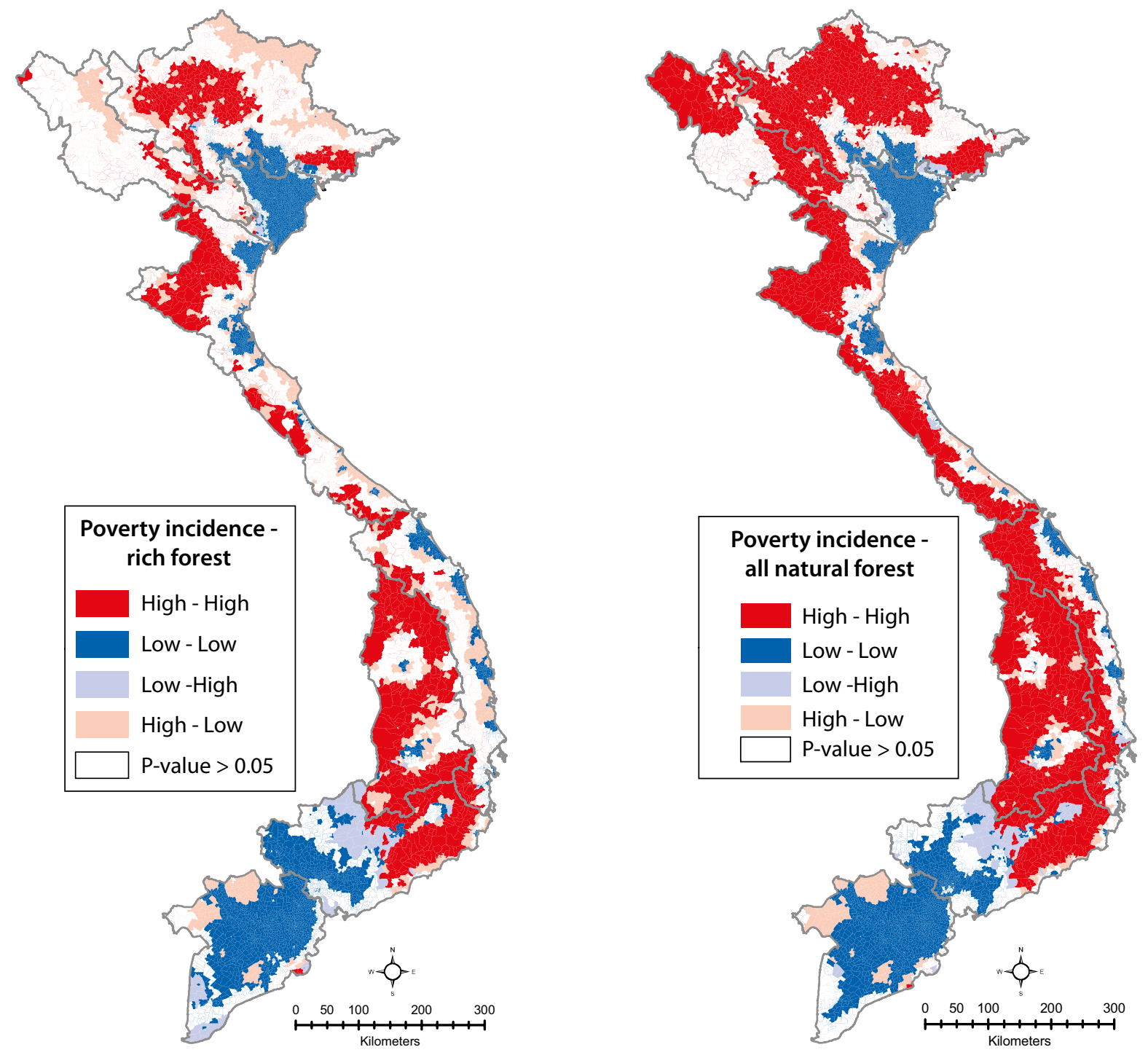

Figure 1.4. Correlation between poverty incidence and forest cover in Vietnam

Source: Müller et al. 2006 based on authors' calculations 


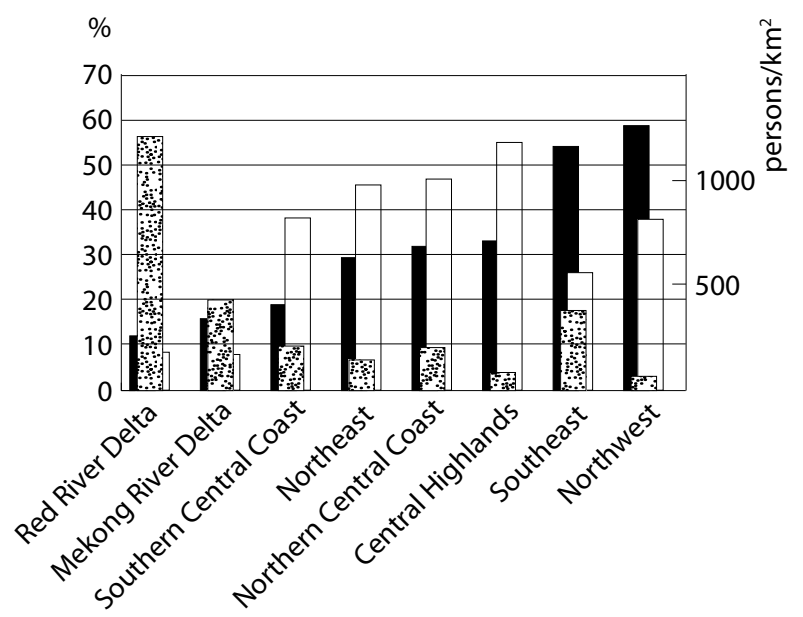

Forest cover

Poverty rate

Population density

Figure 1.5. Correlation between poverty rate, forest cover and population density in Vietnam

Source: FAO (2005) cited in Nguyen (2005)

Not only are Vietnam's forests important for local livelihoods, but the country is ranked $16^{\text {th }}$ in the world in terms of high biodiversity value, hosting $6.5 \%$ of the total species on the planet (MONRE 2006). Seventy per cent of Vietnam's floral species and $90 \%$ of its fauna species have their habitat in forest ecosystems (Vo 2002). Since 1975, Vietnam's biodiversity has been increasingly under threat, mainly from commercial logging, land conversion, extension of aquaculture production and infrastructure development. In 1992,

721 plant species in Vietnam were threatened (including 337 vascular plant species and 19 lower species); this number had increased to 1056 species by 2006 (MONRE 2006).

\subsection{Key drivers of deforestation and forest degradation in Vietnam}

On average, 62000 ha of forest in Vietnam was lost each year from 2002 to 2009 (DoFP 2010). Hoang et al. (2010) mapped several drivers and quantified their respective contributions to deforestation and degradation for 2004-2008 (Table 1.3).

Drivers of deforestation and forest degradation and their underlying causes vary greatly from region to region (Hoang et al. 2010; Table 1.3). For example, while forest loss in the country's northeast has largely been due to conversion into agricultural land for food crops, forest land in the highland plateau areas has been converted to higher-value commercial and perennial crops. In the Mekong Delta, a large area of forest has been converted to shrimp farms and aquaculture production (Doan 2009, UN-REDD 2009). Understanding local conditions is a prerequisite when designing efforts to reduce deforestation and forest degradation.

The drivers of deforestation also differ from one historical period to another. Between 1943 and the 1970s, much of the forest loss was due to war (UN-REDD and MARD 2010). In the 1980s and 1990s, forest loss occurred because of agricultural expansion driven by people migrating from the lowlands into upland forested areas (FORMIS 2005). More recently, forest loss has occurred because of unsustainable extraction and high demand for land clearing (R-PP Vietnam 2011). Following is a discussion of the direct and indirect drivers and underlying causes.

\subsubsection{Direct drivers}

Currently, the main direct causes of deforestation (as described in Vietnam's R-PP and confirmed by the Ministry of Agriculture and Rural Development (MARD 2007a), WertzKanounnikoff and Kongphan-Apirak (2008), UN-REDD (2009) and Hoang et al. (2010)) are: 1) land conversion for agriculture, including high-value perennial crops; 2) land conversion for infrastructure, especially hydropower installations; 3) unsustainable logging (both legal and illegal logging); and 4) forest fires.

\section{Land conversion for agriculture}

Land conversion is considered a main driver of deforestation in both natural forest and plantations (Table 3). According to Vietnam's Department of Forest Protection (DoFP 2010), about 25000 ha of forest land was converted to other land uses each year from 2003 to 2009 (Figure 1.6). Most of this was converted to farmland, including small-scale agricultural plots and swidden. The area dedicated to industrial crops, such as coffee, rubber and cashew, has also increased considerably during recent years, from 1.634 million ha in 
Table 1.3. Increase-decrease in forest area in Vietnam, 2004-2008 (compiled from MARD annual report, Doan Diem 2009) (unit: ha)

\begin{tabular}{|c|c|c|c|c|c|c|}
\hline Forest category & 2004 & 2005 & 2006 & 2007 & 2008 & Total \\
\hline Forest land with forest & 12306859 & 12616699 & 12873850 & 12903423 & 13118773 & - \\
\hline 1. Natural forest & 10088288 & 10283173 & 10410141 & 10348914 & 10348591 & - \\
\hline a) Reasons for increase & 161912 & 215118 & 112331 & 59204 & 32974 & 581539 \\
\hline Natural forest increase & 161912 & 178596 & 74328 & 59204 & 32974 & 507014 \\
\hline Other forest & - & 36522 & 38003 & - & - & 74525 \\
\hline b) Reasons for decrease & 53523 & 35311 & 35588 & 85126 & 63278 & 272826 \\
\hline Legal logging & 238 & 530 & 120 & 376 & 355 & 1619 \\
\hline Forest fire & 2141 & 446 & 259 & 697 & 109 & 3652 \\
\hline Insects and disease & - & 197 & 68 & 58 & - & 323 \\
\hline Illegal logging & 3061 & 7989 & 6199 & 1694 & 3395 & 22338 \\
\hline Land use conversion & 24916 & 15260 & 18449 & 11808 & 23508 & 93941 \\
\hline Other reasons & 23167 & 10889 & 10493 & 70493 & 35911 & 150953 \\
\hline 2. Planted forest & 2218571 & 2333526 & 2463709 & 2554509 & 2770182 & - \\
\hline a) Reasons for increase & 205257 & 158624 & 195601 & 178779 & 203601 & 941862 \\
\hline Newly planted & 182699 & 154787 & 171444 & 178779 & 174918 & 862627 \\
\hline Others & 22558 & 3837 & 24157 & - & 28683 & 79235 \\
\hline b) Reasons for decrease & 43566 & 35120 & 39231 & 45153 & 45334 & 208404 \\
\hline Legal logging & 16362 & 19046 & 23194 & 26855 & 35147 & 120604 \\
\hline Fire & 3422 & 4818 & 1276 & 1631 & 679 & 11826 \\
\hline Insects and disease & - & 153 & 71 & 279 & 18 & 521 \\
\hline Illegal logging & 600 & 1159 & 2249 & 136 & 502 & 4646 \\
\hline Land conversion & 10026 & 8237 & 12441 & 4802 & 8988 & 44494 \\
\hline Others & 13156 & 1707 & - & 11450 & - & 26313 \\
\hline
\end{tabular}

Source: Hoang et al. (2010)

2005 to 1.886 million ha in 2008. In the Central Highlands alone, coffee plantations accounted for the conversion of a total of 500000 ha between 1990 and 2000.

Similarly, the area used for aquaculture, primarily shrimp farms in mangrove areas, doubled between 1991 and 2001 (FCPF 2011) driven by government schemes introducing a number of incentives to promote shrimp farming in coastal areas. A comparison of the area of mangroves with the area of shrimp farms in coastal regions is given in Figure 1.7. The schemes were very successful but resulted in uncontrolled expansion of this lucrative business and thereby the destruction of mangroves, including newly planted forest (Hawkins $e t$ al. 2010). About $5 \%$ of the mangrove area is destroyed annually (GSO 2008).

\section{Land conversion for infrastructure construction}

As noted by Freshfields Bruckhaus Deringer (2007), infrastructure in Vietnam is considered to be underdeveloped, constraining the nation's economic growth. To stimulate infrastructure construction, the government has strongly encouraged private sector investment during the past decade. In addition, the government has allocated about $45-50 \%$ of its budget towards infrastructure development (i.e. > 10\% + of GDP).

As a result of rapid and large-scale infrastructure development, large areas of forest have been converted, mainly for hydropower installations as well as roads. More than 15000 ha of natural forest has been destroyed in the construction of dams along the Dong Nai River, and more dams 


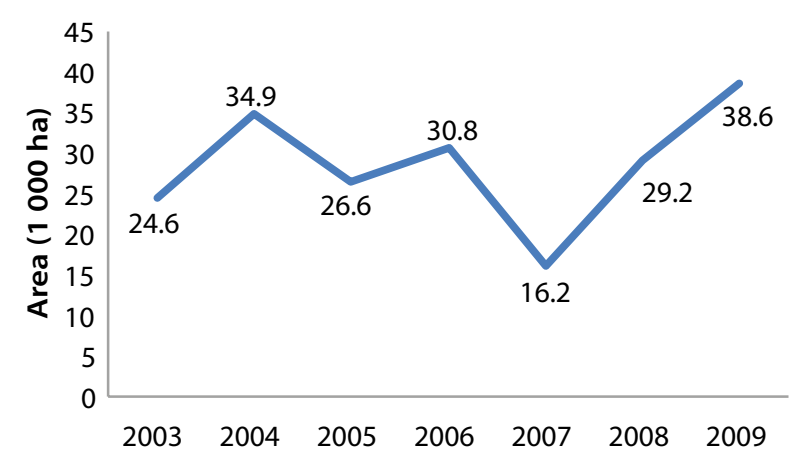

Figure 1.6. Conversion of forest land in Vietnam, 2003-2009

Source: DoFP (2010)

are being planned (FCPF 2011). Furthermore, construction of infrastructure, such as roads and power plants, often displaces local populations, who move into and convert forest areas (see Chapter 3 for more details). For example, the establishment of the largest dam in Vietnam, the 1920 MW Hoa Binh dam on the Da River in the north of the country, in 1994 led to the resettlement of 58000 people, who had no alternative but to clear the steep hillsides along most of the reservoir edge, leading to further deforestation and soil erosion (Hirsch et al. 1992).

According to Eames (cited in Sai Gon Times 2009), inappropriate infrastructure projects (roads) have adversely affected the biodiversity of the Chu Yang Sin National Park, which contains 59278 ha of rolling hills and mountain forests.

More detailed analysis of the underlying causes of land conversion is given in section 1.2.2.

\section{Logging}

Although, as the government points out, data on logging is lacking (Pham 2009), logging is considered a main driver of forest degradation. Underlying this contention is the prevalence of poor management practices by commercial logging operations as well as timber harvesting by rural households. In this context, logging includes both 'legal exploitation' or the harvesting of plantations for timber export, paper production and mining construction by officially government-licensed, large-scale commercial logging operations, and 'informal' logging, usually smaller-scale exploitation that occurs without government permission or licences and is therefore considered illegal.

Before 2000, logging (legal and illegal) occurred in both natural forests and plantations and even today remains a significant threat to biodiversity (MARD 2007a). A large amount of illegal logging of immature stands occurred in the 1990s in forests planted to supply paper mills (Le 1998). The demand for raw material to feed the paper mills led to large-scale encroachment into natural forests.

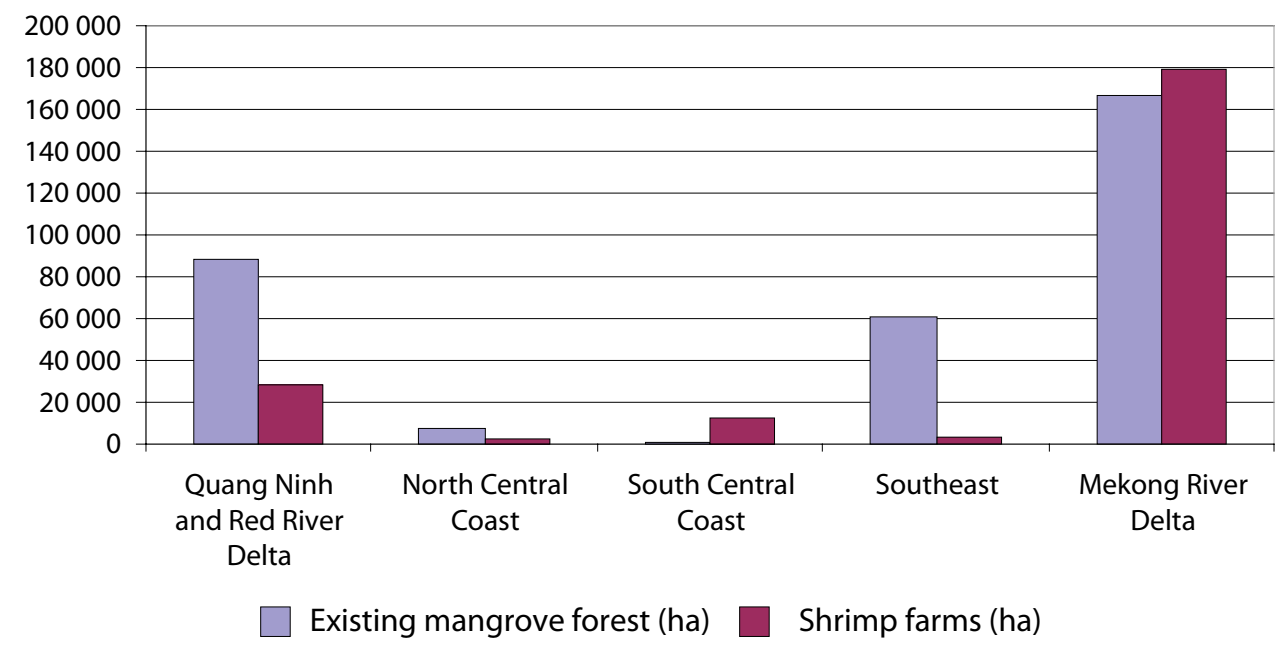

Figure 1.7. Areas of mangroves and shrimp farms in Vietnam 
For example, more than 80000 ha of mostly natural forest was cleared to supply the Bai Bang Paper Company during 1983-1993 (Le 1993).

According to the DoFP (2010), of the average area logged each year from 2002 to 2009 (33 824 ha), $72.6 \%$ was licensed and $27.4 \%$ was unlicensed (Figure 1.8). 'Licensed' exploitation is confined to logging that takes place in officially designated production forest, while exploitation in the remaining natural forest is perceived to be illegal, although some licences are given for natural forests. Thus, in 2009, of the total area logged under licences (41 $238 \mathrm{ha}$ ), 93\% was in planted production forest and only $7 \%$ in natural forest. In contrast, unlicensed logging occurs mostly in natural forest $(96 \%)$, with only $4 \%$ in planted forest; hence, 25817 violations of state regulations occurred, with $48605 \mathrm{~m}^{3}$ of timber confiscated (FCPF 2011). In Dak Nong Province in the Central Highlands, 455 cases of illegal logging, corresponding to 353 ha of forest, were reported in 2009 ( $\mathrm{Ngoc} 2010$ ). Most of this unlicensed logging occurs at a small scale, but is carried out by multiple actors and is often driven by medium to large timber-trading companies.

\section{Forest fires}

About 6 million ha of Vietnam's forests is considered vulnerable to fire (FCPF 2011). According to the DoFP (2010), an average of 704 forest fires occurred each year between 2002 and 2010, leading to an average loss of 5081.9

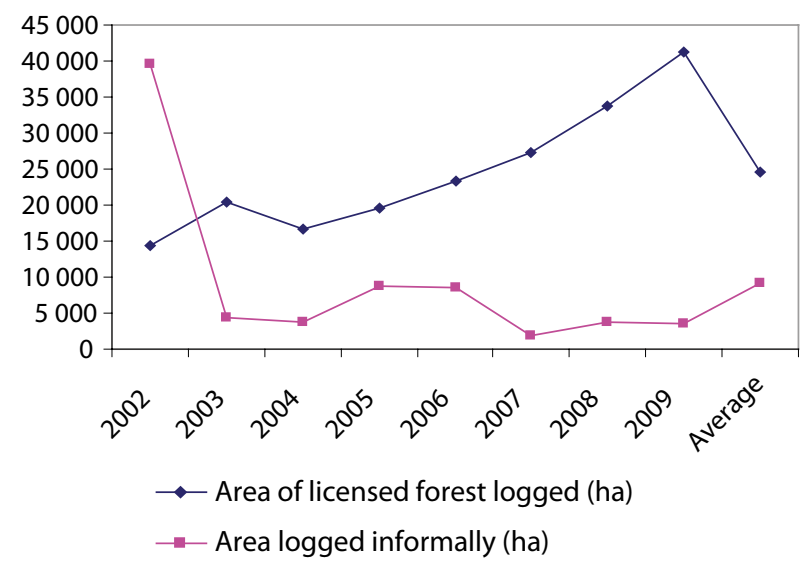

Figure 1.8. Area of forest logged (ha), 2002-2009

Source: DoFP (2010) ha of forest annually. The amount fell slightly during this period: 7500 ha a year in 2002 to 3800 ha in 2009 (Figure 1.9). According to forest officials interviewed, most of the fires occurred in plantations and production forests, where harvesting of non-timber forest products (NTFPs), mainly honey, inadvertently leads to fires. Slash-and-burn practices caused $60.8 \%$ of fires, and hunting, honey and wood collecting led to $18 \%$ of fires; $5 \%$ are caused by accident or negligence, and $11.2 \%$ have other causes (MARD 2010). Comparatively few fires occur in natural forests. For example, in 2009, 1560.5 ha of forest burned, with $9.6 \%$ occurring in natural forests; the remaining $90.4 \%$ occurred in plantations and production forests.

\subsubsection{Indirect drivers}

The main indirect causes of deforestation that have been identified include growing demand for forest products and agricultural land driven by population growth and migration, economic growth and increasing demand for wood for the pulp and paper industry, construction and fuel (Sunderlin and Huynh 2005). However, underlying these factors are policies that facilitate unsustainable logging and unplanned conversion, as discussed below.

\section{Growing demand for forest and agricultural products}

Vietnam's population is estimated to reach 100 million by 2020 with $1.07 \%{ }^{3}$ annual growth leading to increasing demand for food, fuel and forest products. In 2009, the total population of Vietnam was 89 million, of which $72 \%$ lived in rural areas (RECOFTC, ASFN and SDC 2011); this proportion includes an estimated 25 million members of ethnic minority groups who live in and near forest areas (FORMIS 2005).

To cope with both rapid population growth and high population density (FAO 2010), especially in the fertile coastal plains, the government developed rural resettlement policies and an agriculturebased policy of new economic zone development to encourage migration to mountainous areas and islands. These migrants often cleared forest for

3 http://www.indexmundi.com/vietnam/demographics_ profile.html. 


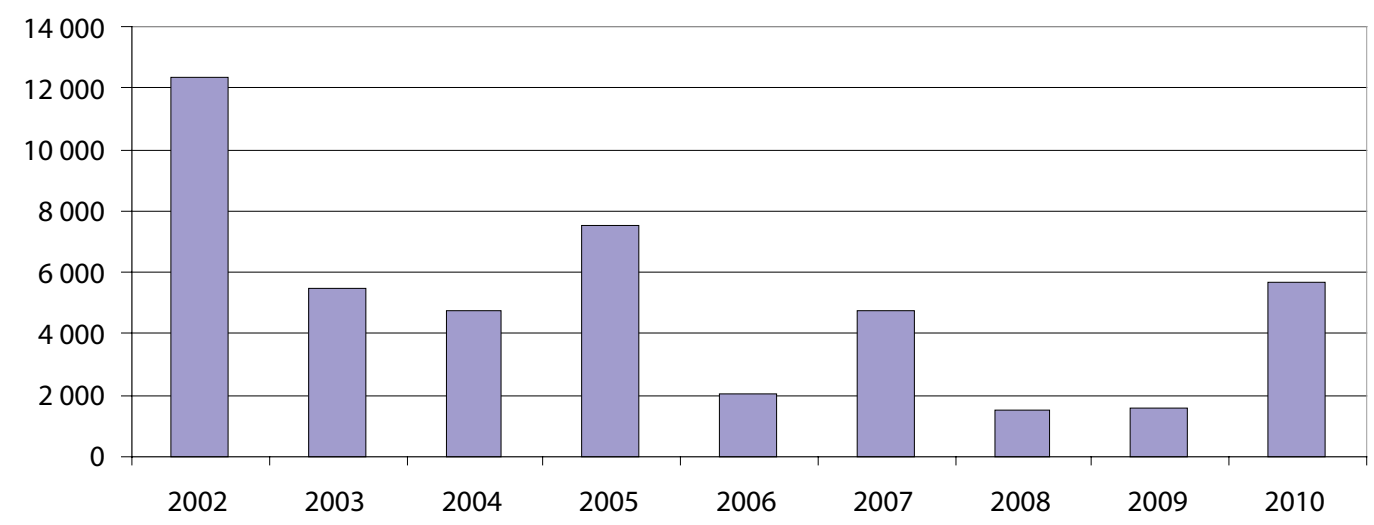

Figure 1.9. Area of forest in Vietnam destroyed by fire, 2002-2010 (ha)

Source: DoFP (2010)

agriculture and pasture to make a living (Desbarats 1987, Oberai 1987, Do 1998, Dang 2005,

Thomas et al. 2008).

Food production and fuelwood are increasingly likely to compete for land with the plantations that are currently planned to produce raw material for the paper and timber sectors, as Vietnam's population continues to grow and becomes wealthier. For example, the government's aim of achieving self-sufficiency in food and food grains for ethnic minority groups in mountainous areas accelerated the clearing of forest land for agriculture. In 2006, 23744 ha of forest land was claimed for agriculture; by 2008 , this had increased to 73762 ha (Table 1.4). Policy incentives for growing cash crops (coffee, rubber, cashews, etc.) also led to the loss of forest land.

On the other hand, out-migration to seek employment in urban centres might have had a positive impact on forests. Out-migration, which is one of the few mechanisms available for people wishing to gain employment that provides a reasonable cash income to support their rural-based households, is not recognised in current policies, national strategies or programmes on poverty and environment (MOLISA 1997, Philip 1998, Dang 1999, 2005). Dang (2005) emphasised migration as an effective coping strategy to lift households out of poverty, especially after natural disasters, and make them less reliant on farming and forest activities, which are often risky because income and expenditure are governed by the market price - over which farmers have no control. This trend is also creating new opportunities for women, by providing them with access to employment outside the home and allowing them some choice and independence (interviews conducted in 2010). The number of young and unmarried women migrating from rural area to cities and industrial parks has been increasing (GSO and UNFPA 2004), resulting in a large movement of rural labour out of the agriculture and forestry sectors. This implies radical changes in agriculture and forestry sector development.

Improved living standards in Vietnam and global growth are increasing the demand for timber and other forest products, resulting in further deforestation (see Chapter 3 for more details).

\section{Underlying causes of deforestation and forest degradation}

As noted above, underlying political economy factors often drive the direct and indirect causes of deforestation. Some of the underlying factors leading to deforestation are discussed in this section; the political economy of Vietnam is explained in detail in Chapter 3.

\section{Development policies}

Many underlying causes of deforestation and forest degradation can be traced to policies that prioritise agricultural and infrastructure development, as shown in Table 1.4.

Agricultural practices and infrastructure development (roads) may cause environmental 
Table 1.4. The impact of national development policies on forests in Vietnam

\begin{tabular}{|c|c|c|}
\hline Policy & Rationale for policy & Impact on forests and forest dependent people \\
\hline $\begin{array}{l}\text { Agricultural development } \\
\text { (e.g. Decree } 14 / C P, 1993, \\
\text { enabling households to } \\
\text { obtain credit to develop } \\
\text { agroforestry, fisheries } \\
\text { and rural economy; } \\
\text { Decree } 12 / C P \text { on reforms } \\
\text { of agricultural state } \\
\text { enterprises in 2001) }\end{array}$ & $\begin{array}{l}\text { Address poor } \\
\text { economic } \\
\text { effectiveness of } \\
\text { transfer of land use } \\
\text { rights } \\
\text { To ensure food } \\
\text { security and land } \\
\text { access for increasing } \\
\text { rural population }\end{array}$ & $\begin{array}{l}\text { - Unsustainable cultivation on sloping land in } \\
\text { mountain areas increases the risk of erosion when } \\
\text { pressures for food cultivation increases. } \\
\text { Expanded agricultural activities encourage } \\
\text { encroachment into forests leading to deforestation } \\
\text { and forest degradation. The degradation of the } \\
\text { natural resource base in turn impinges on the } \\
\text { livelihoods of rural communities. More small } \\
\text { farmers are forced to work harder, often on } \\
\text { shrinking farms on marginal land, to maintain } \\
\text { household incomes. } \\
\text { Surface water pollution caused by industries and } \\
\text { livestock, have affected the health of all people, } \\
\text { with most impacts on the poor } \\
\text { Un-sustainable agriculture cultivation negatively } \\
\text { effects the harvesting of crops and increases the } \\
\text { cost of agriculture production }\end{array}$ \\
\hline $\begin{array}{l}\text { Development of } \\
\text { infrastructure (e.g. five- } \\
\text { year socio-economic } \\
\text { development plan } \\
\text { 2006-2010, Vietnam's } \\
\text { Strategy for Electricity } \\
\text { Development) }\end{array}$ & $\begin{array}{l}\text { Address transport } \\
\text { needs } \\
\text { - Increase access } \\
\text { to market of rural } \\
\text { communities leading } \\
\text { to their improved } \\
\text { living standard } \\
\text { Address increasing } \\
\text { demand for energy } \\
\text { caused by economic } \\
\text { development }\end{array}$ & $\begin{array}{l}\text { - Natural forest and protected areas are cleared } \\
\text { out for road and hydropower plant development } \\
\text { leading to loss of wildlife habitat and biodiversity } \\
\text { Displacement of people which was destructive to } \\
\text { their livelihood and culture } \\
\text { The number of landless farmers increased. The poor } \\
\text { fall into a vicious circle exits: no land - no chance } \\
\text { to access credit - no development - no escape } \\
\text { from poverty. } \\
\text { The vulnerabily of women, children and ethnic } \\
\text { minority groups increases due to exhaustion of } \\
\text { natural resources. }\end{array}$ \\
\hline $\begin{array}{l}\text { Land allocation (e.g. } \\
\text { Land Law 2003, Law on } \\
\text { Forest Protection and } \\
\text { Development 2004) }\end{array}$ & $\begin{array}{l}\text { Meet the needs } \\
\text { of the } 25 \text { million } \\
\text { people living in the } \\
\text { mountains } \\
\text { Reduce poverty in } \\
\text { rural upland areas }\end{array}$ & $\begin{array}{l}\text { Existing land distribution and re- allocation systems } \\
\text { do not give adequate attention to the needs of the } \\
\text { poor hence more people become landless } \\
\text { Inappropriate land use planning and the cultivation } \\
\text { of steep hillsides has reported to have rapidly } \\
\text { decreased forest areas and productivity of the land } \\
\text { and negatively affected the ecological balance. } \\
\text { Framework provides incentives for land clearing, } \\
\text { and the process of degradation is accelerating } \\
\text { due to lack of financial means for additional input } \\
\text { factors (e.g. fertilisers) }\end{array}$ \\
\hline
\end{tabular}

Sources: Thomas et al. (2008), Nguyen (2008), Swallow et al. (2008), FCPF (2010), UN-REDD and MARD (2010).

pollution and negatively affect the structures of plant and animals populations and communities. The market for wildlife, timber and NTFPs also intensifies the pressure on forest ecosystems, creating considerable challenges for forest protection in Vietnam (Delang 2005, TRAFFIC 2008).
Weak governance

Ineffective management of state forest enterprises. Before the reforms of the 1990s, state forest enterprises (SFEs) were the key state players in the forestry sector. The SFEs managed forests and forest activities including forest harvesting, forest 
product processing, forest planting operations and forest rehabilitation; they also provided public services to facilitate socio-economic development and ensure national defence and security in mountainous areas. During 1961-1990, these agencies were instrumental in developing $71.12 \%$ of the total area of plantations in the country (de Jong et al. 2006). As is generally the case of state enterprises in developing countries, SFEs were notoriously ineffectively managed (de Jong $e t$ al. 2006). Therefore, when Vietnam shifted to a market-oriented economy, reforms of SFEs were initiated. SFEs no longer received state funding; instead, they were expected to finance their own activities, with those incurring a loss being disbanded. Despite their history of ineffective management, SFEs remain in charge of harvesting, protecting and selling timber for state revenue and often practise unsustainable logging (Ogle et al. 1999, de Jong et al. 2006, Hoang 2006).

Weak governance at local level. Despite the establishment of a clear governance structure at the central and provincial levels (as described in Chapter 2), at the local commune level, governance in general is poor and governance of forests in particular is neglected. Commune authorities, responsible for field-level activities, often lack the necessary competence to oversee large areas of forest and carry out proper monitoring. Indeed, the qualifications of public servants in general fall far short of the requirements for the assigned tasks and duties (Pham et al. 2009). Poor governance has also allowed corruption to continue unabated. For example, Sikor (1998) found that more than 50\% of the total funding allocated to Programme 327 was diverted to other purposes. There are reported cases in Daklak Province where forest protection fees were debited without consultation and used to pay taxes or fees that households had failed to pay earlier (Sunderlin and Huynh 2005).
Weak land administration. In Vietnam, land is administered by the state for the good of all the people. In 1990, the state decided to allocate forest land to local people on an individual basis. However, because of the complicated history of land administration and poor records, insufficient information was available to manage the numerous plots effectively, leading to elite capture and more opportunities for corruption (AusAID 2000). Most of the interviewees revealed a number of reasons for the high incidence of corruption in forest land administration: inconsistencies in legislation and policies create gaps in which bribery can thrive; the slow operation of the 'one-stop-shop' office forces extra 'efforts' to speed up the process; and the unclear division of duties and allocation of tasks among state officials at different levels. The inadequate prices offered for land create further gaps, accompanied by the mechanism of 'askinggiving' for land that hampers efforts to tackle corruption related to land administration (AusAID 2000, Chinh 2010).

\section{Lack of financial resources for forest protection}

Although Vietnam has spent much of the state budget on forest management and protection, it still falls short of requirements (GoV 2006). For example, in Yok Don National Park, it is estimated that effective forest protection activities would cost VND 346185 (USD17) per ha per year (Hoai 2010). However, the amount allocated from the state budget is much smaller: Decision 100/2007/ QD-TTg of 6 July 2007 provides national support to the local budget for protection forests and special forests of VND 100000 (USD5) per ha per year (GoV 2007). In contrast, the opportunity costs of agricultural and aquacultural production are high, and cannot be paid off by this low level of payment. 


\section{Institutional environment and distributional aspects}

$\mathrm{T}$ The forestry sector in Vietnam is influenced by multiple institutional factors, global as well as local. The present forestry policy was developed in the context of wider change. First was the wide-reaching policy reform, known as Doi Moi, which transformed the centralised command economy to a market-oriented, multisector economy (see Chapter 3 for more details). Second, following global trends, the policy tried to balance economic development with the need for forest protection and conservation with varying degrees of success. Finally, through the processes of decentralisation, the forestry sector was decentralised within the strongly entrenched hierarchy of the party system that still dominates the government structure.

This chapter focuses on these structuring institutions, starting with international agreements to which Vietnam is a party, and then continuing with a discussion of the structure of Vietnam's forest governance. The final section highlights global institutions affecting forest governance and deforestation and forest degradation processes.

\subsection{Governance of forests in Vietnam}

\subsubsection{International agreements}

The government of Vietnam has signed several international agreements to join global efforts to overcome environmental problems. Most important among these are the Convention on Biological Diversity (CBD), the Convention on International Trade in Endangered Species of Wild Fauna and Flora (CITES) and Forest Law Enforcement, Governance and Trade (FLEGT) (Table 2.1).

After a decade of implementing these international agreements and treaties, some issues have emerged that might provide useful lessons for future REDD+ implementation in Vietnam. First, funding allocated for CBD implementation has been routinely misused for other needs (Pham 2006). The establishment of an accountable and transparent mechanism for REDD+ funding is therefore an important measure. Several other factors have also led to poor implementation of these international policies: transaction costs due to

Table 2.1. Key international agreements to which Vietnam is party

\begin{tabular}{lll}
\hline International agreement & Signing date & National policies for implementation \\
\hline $\begin{array}{l}\text { Convention on Biological } \\
\text { Diversity (CBD) }\end{array}$ & 1992 & $\begin{array}{l}\text { Passed the Law on Biodiversity in } 2008 \text { and formulated the } \\
\text { National Biodiversity Action Plan }\end{array}$ \\
$\begin{array}{l}\text { Convention on International } \\
\begin{array}{l}\text { Trade in Endangered Species } \\
\text { (CITES) }\end{array}\end{array}$ & 1994 & $\begin{array}{l}\text { Implemented a series of policies, laws and by-laws on } \\
\text { the wild animal trade to bring the country into line with } \\
\text { international conventions. }\end{array}$ \\
$\begin{array}{l}\text { Forest Law Enforcement, } \\
\text { Governance and Trade (FLEGT) }\end{array}$ & 2010 & $\begin{array}{l}\text { Set up the FLEGT standing office and three subtechnical } \\
\text { working groups }\end{array}$ \\
\hline
\end{tabular}


overlapping and unclear functional and managerial duties of different agencies; weak coordination among stakeholders; weak infrastructure and management capacity of agencies to respond to practical demands; and low capacity of national focal points (Pham 2006, Pham et al. 2008, 2009). Thus far, as confirmed during the interviews for this study, this 'business as usual' approach has been observed in the REDD+ formulation process in Vietnam, requiring serious thought on ways to prevent this.

Second, while these international agreements focus on sustainable development and governance, the translation and implementation of these policies mainly focus on conservation. The rights of communities, particularly indigenous groups, have not been adequately considered. Policymaking processes fail to include consultation with communities of forest exploiters, growers, traders and users and do not take into account the sustainable management practised by indigenous communities (CITES Scientific Authority of Vietnam 2008). As a result, laws and policies on wildlife protection are implemented ineffectively, and monitoring and regulatory mechanisms are often neglected (CITES Scientific Authority of Vietnam 2008). REDD+ policies should take a different approach, making full use of the knowledge of various social groups, and the monitoring system should be rooted in both national law enforcement and customary law.

Third, the level of understanding of the content and requirements of these international agreements, as well as of the implications of international policy instruments in relation to trade and biodiversity, is still limited not only among forestry researchers and trainers, but also among forest managers and planners at the provincial level; this leads to failure in their implementation (Nguyen et al. 2004, ProForest 2009).

The government has acknowledged the importance of climate change in sustainable development of the country and is currently planning to integrate climate change into its forthcoming Socio-Economic Development Plan (SEDP) (see Chapter 3 for further details); it is also developing a National Target Plan (NTP) for responding to climate change. However, while numerous challenges are emerging in relation to coordination for NTP implementation, most interviewees claimed that the current draft of the SEDP has not been able to 1 ) adequately address climate change adaptation and disaster risk management in the sector and provinces targeted for development (in terms of either objectives or solutions); 2) mainstream climate change as a development challenge across all sectors of the economy and society; 3 ) set targets for climate change adaptation and climate proofing; 4) specify climate change adaptation and mitigation plans in the development of the regions; or 5) find a balance between climate change adaptation and mitigation.

\subsubsection{National forestry policies and legal framework}

The forestry sector in Vietnam has three major goals. The first goal is economic development, to be achieved by fostering commercial tree plantations, including agroforestry and industrial plantations, developing mixed forestry-agricultural farming systems and developing economically viable processing enterprises and industries that use timber and other forest products. The second goal, environmental protection, aims to increase forest cover through natural regeneration and planting on deforested land, and to increase the number of environmental services through the conservation of valuable biodiversity resources and watershed areas. The final goal is social; it focuses on poverty reduction, through allocation of forest land to households and communities, community forestry, forestry extension services and generation of employment in forest enterprises. The key legal documents formalising this vision are discussed in the following.

\section{National Forestry Development Strategy 2006-2020}

As MARD states in its foreword to the national Forestry Development Strategy, the strategy is necessary because Doi Moi and overall national development require a shift from 'traditional forestry' - mainly based on exploitation of natural forest by the state - to 'socialised forestry' (MARD 2007d: 5). Consequently, the strategy seeks to balance the push for economic growth with the social and environmental aspects of forestry through five programmes (Figure 2.1; GoV 2006, MARD 2007d, VNFOREST 2011). The achievement and shortcomings of each programme 
are discussed in detail by Le (2010), who draws on the FAO assessment matrix and indicators.

The stated objectives of the strategy are:

to sustainably establish, manage, protect, develop and use 16.24 million ha planned for forestry; to increase the ratio of land with forest to $47 \%$ by 2020 ; to ensure wider participation of various economic sectors and social organisations in forest development; to increase contributions of the forestry sector to socio-economic development, environmental protection, biodiversity conservation and environmental services supply; to reduce poverty and improve the livelihoods of rural people in the moutainous area (MARD 2007: 45).

There is thus heavy emphasis on efforts to increase forest cover, improve soils, protect water resources and control flooding. This commitment reflects an awareness of the threats that watershed forest losses pose to economic development in the plains and coastal areas (Poffenberger and Nguyen 1998). The most important focus of the strategy is the "socialisation" of the forestry sector, which involves engaging various economic sectors and social organisations in the sector's development.
Improving income, eradicating poverty and reducing the number of poor households in forest areas are among the important tasks explicitly stated in this strategy.

The strategy was written in 2006 before the discussions on REDD+. This timing created the problem of linking REDD+ to the strategy. Although the strategy emphasises environmental aspects and includes a special programme for forest protection, biodiversity conservation and development of environmental services, its overarching goal is economic development. Despite recognition of a need to adjust the traditional approach, change is coming only very slowly and the amount of attention given to social and environmental objectives is still insufficient (CISDOMA 2009).

\section{Forest Protection and Development Law 2004}

Vietnam's Forest Protection and Development Law sets out rules for forest classification; the state's rights in relation to forest protection and development; allocation of forests to village communities; forest prices; registration of forest use rights; ownership rights over planted production forests; forest statistics and inventory;

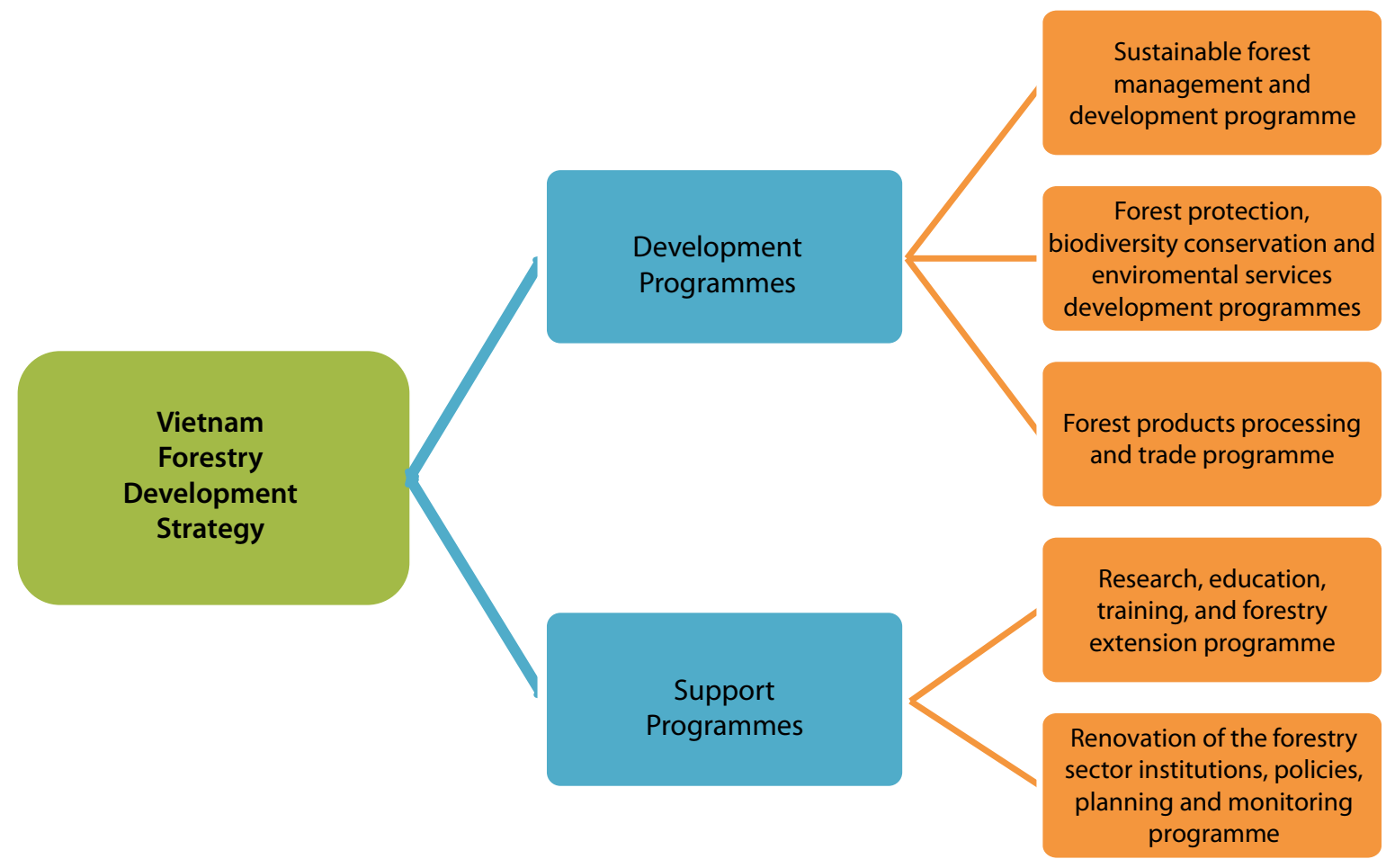

Figure 2.1. Vietnam's Forestry Development Strategy 
monitoring of forest resource development; and responsibilities for forest protection. The law directs state policies for investing in, encouraging and supporting forest protection and development, expanding the area of forest plantation and the market for forest products. It also grants forest users some managerial rights over the forest, as well as the right to generate income and benefits from their labour and investments in forest land within the overall regulatory framework.

The major substance of this law concerns conservation aspects, such as protection of forest ecosystems, forest plants and animals, and forest fire fighting and prevention. However, the law also addresses the exploitation and trade of forest products. According to the law, exploitation of forest products must comply with forest management regulations, and not compromise the objectives of forest conservation and forest landscape protection. Efforts were made to introduce private forest management in Vietnam following the approval of the Forest Protection and Development Law.

\section{The Biodiversity Law 2008}

Vietnam's Biodiversity Law regulates the rights and obligations of organisations, households and individuals in relation to biodiversity conservation and sustainable development. The aims of the law are to prevent biodiversity decline, conserve precious plants and animals and support the sustainable social and economic development of the country. The law sets out protective measures to support the livelihoods of people who depend on access to natural resources and biodiversity. It also offers benefits for those who possess traditional knowledge on biodiversity, thus encouraging them to participate in biodiversity conservation and rehabilitation. This law also creates institutional planning at national and provincial levels, including the sustainable development of natural ecosystems and the protection of rare species.

The Biodiversity Law demonstrates the government's commitment to biodiversity conservation but, as our interviewees noted, it has several shortcomings. These include inadequate attention to biodiversity corridors and weak enforcement due to lack of human resources, experience and technical expertise in the area of biodiversity conservation. Furthermore, the voice and concerns of the poor have not been heard, and are not considered in this law. Another concern is that, as both MARD and MONRE are deeply involved in biodiversity conservation, a conflict of interest and/or competition between the ministries could create further obstacles in implementing this law. Moreover, the Biodiversity Law also allows for commercial breeding and captivity of endangered species, which may lead to over-exploitation, particularly given Vietnam's history of poor management of breeding farms.

\section{Benefit-sharing policies}

In 2001, the Prime Minister issued the two most important decisions relating to the management of natural forest and benefit sharing: Decision 08/2001/QD-TTg and Decision 178/2001/QD$\mathrm{TTg}$, respectively (Do and Le 2001). The key points of these policies are as follows:

- In protection forests: Households that sign contracts for and invest in protection forests are entitled to receive payments for protecting, regenerating and planting forests, in accordance with the contracts signed with the forest management boards. If a household covers all the costs for the regeneration and planting on land without forest cover, it will be entitled to collect fuelwood and NTFPs under the canopy (20\% in timber forests and $30 \%$ in bamboo forests); all agricultural and forest products when the forest is ready for harvest; and 85$90 \%$ of harvested products after taxes are paid.

- In production forests: Households and individuals may collect dead trees as well as trees damaged by fire or other natural disasters or during the process of applying silvicultural technologies, and may harvest forest products to meet their own domestic consumption needs. Newly established families must apply for approval of their wood requirements to construct a house (no more than $10 \mathrm{~m}^{3} /$ family). After the harvesting plan is approved, they are entitled to receive $100 \%$ of products from replanting on degraded forest land or $70-80 \%$ from maintaining regenerated forest (after shifting cultivation), $2 \%$ a year of forest that has $100 \mathrm{~m}^{3}$ of growth per ha annually, and $95 \%$ of forest products from bamboo forest (after taxes are paid). 
- Special-use forests: Forest owners (households or individuals) are allowed to harvest, carry out research and engage in ecological tourism in accordance with the relevant laws and regulations.

These policies demonstrate the government's commitment to securing a more participatory role for local people in the protection and management of forests. That is, in becoming forest owners and sharing the benefits, local people are motivated to manage forests well.

\section{Decision 380 and Decree 99 on payments for environmental services}

In a study examining the potential of payment for environmental services (PES) schemes in Vietnam, Wunder (2005) pointed out that in a country such as Vietnam that takes a top-down approach to governance, 'Payment is good but control is better'. In 2008, the government issued Decision 380, the aim of which was to pilot payments for forest environmental services (PES) in preparation for nationwide scaling-up through the approval of Decree 99/2010/NĐ-CP in 2010. This decree provided new opportunities for a hybrid mechanism combining market-based instruments with a command-and-control system (see Chapter 4 for further details).

Under Decision 380/Decree 99, payments can be made indirectly, with the government acting as intermediary, or directly, based on negotiations between buyers and sellers. However, direct transactions are not taking place in Vietnam because of a lack of recognition of the value of environmental services and a low level of willingness to pay among users of environmental services. For indirect payments, Decision 380/ Decree 99 states that the money collected by MARD is to be deposited into the Forest Protection and Development Fund, which is managed by MARD at the central level and by the People's Committee (PC) at the provincial level. Of the total sum collected, MARD is to retain 5\%, with $10 \%$ remaining in the provincial Forest Protection and Development Fund to cover the costs of its services, and the remaining $85 \%$ to be paid directly to the providers of the environmental services.
Under Decree 99, a forest owner will receive a payment calculated according to the following formula:

\begin{tabular}{|c|c|c|c|c|c|c|}
\hline $\begin{array}{l}\text { Payment } \\
\text { to forest } \\
\text { owner } \\
\text { (VND) }\end{array}$ & $=$ & $\begin{array}{c}\text { Average } \\
\text { fee per } \\
\text { hectare } \\
\text { (VND/ha) }\end{array}$ & $\times$ & $\begin{array}{c}\text { Area } \\
\text { managed }\end{array}$ & $x$ & $\begin{array}{c}\text { Coefficient } \\
\text { K }\end{array}$ \\
\hline
\end{tabular}

a. The average fee per ha of forest (VND/ha) is the total amount received from users of environmental services, less the management costs of provincial authorities, divided by the total area of forest in the catchments, as approved by the agency responsible for the PES agreement.

b. The forest area that is managed for services includes allocated forest areas, rented areas and contracted areas.

c. Coefficient $\mathrm{K}$ defines the local specifics for payment. $\mathrm{K}$ is defined based on the local forest categories managed (protection forests, specialuse forests, production forests), the forest status (rich, medium, poor, restoration forest) and the forest history (natural forest, plantation); these factors are determined by the Provincial People's Committees.

The government claimed that Decision 380 has significantly improved both livelihoods and forest resources (Nguyen 2010). However, Pham et al. (2008) pointed out several challenges in implementing Decision 380/Decree 99. First, these calculations result in a very low payment per hectare, and the areas of forest that people manage are too small for payments to have any significant effect on poverty. Many of these poor people do not even have land use rights. As a result, payments under Decision 380 and Decree 99 are likely to benefit only those who are already better off, with some trickle-down effect to the poor who provide labour for wealthier households (Pham et al. 2008). Lasto and To (2009) also highlighted that several difficulties were encountered during the implementation and scaling-up of the PES projects, especially in relation to the scientific basis for calculating the value of forest services and providing the required funds. Benefit sharing is especially problematic, especially when a PES programme spans several 
localities. Most interviewees also mentioned how different perceptions of the meaning of 'equity' by different groups created difficulties in implementing the $\mathrm{K}$ coefficient, as described above. For example, although several factors are considered in determining the $\mathrm{K}$ coefficient, local people believe that $\mathrm{K}$ should always be equal to 1 because different $\mathrm{K}$ values will lead to inequity.

The strengths and weaknesses of these policies based on respondents' analyses and our review are summarised in Table 2.2.

In general, national policies and legislation are being adjusted to reflect new opportunities; for example, the Forest Protection and Development Law and Decree 99 were established to better assess the role of forests in the provision of environmental services and to create opportunities for compensation where these services are being provided. However, several factors hamper implementation. First, many policies contradict each other and are poorly communicated to lower administrative levels, and their implementation is poorly monitored, thus leading to divergent implementation in different parts of the country (de Jong et al. 2006, Nguyen et al. 2008). Second, with regard to forest and forest land, policies tend to emphasise conservation and protection while overlooking the survival needs of local people, particularly of minority groups. As a result, poverty rates have increased, as have social conflicts between groups (Dinh 2005). Third, economic efficiency was not thoroughly considered during the planning processes, leading ultimately to poor results (de Jong et al. 2006). For example, the programmes target a rapid increase in forest cover, but they failed to take into account the strategic importance of matching tree and wood production to marketing possibilities. Fourth, few quantitative data are available for identification of poverty-environment linkages that could be used to effectively influence environmental policy development; furthermore, there is no definition of clear, pragmatic actions that will allow the integration of poverty issues into environmental programmes and projects (Thomas et al. 2008). Moreover, as discussed in Chapter 1, despite the potentially serious impact of migration on forest, this aspect remains conspicuously absent from poverty-and environment-related policies (Dang 2005).

\section{Table 2.2. Strengths and weaknesses of Vietnam's forest policies}

\begin{tabular}{|c|c|c|}
\hline & Strengths & Weaknesses \\
\hline $\begin{array}{l}\text { Institutional } \\
\text { arrangements }\end{array}$ & $\begin{array}{l}\text { Policies and commitments established } \\
\text { at national level } \\
\text { Villages and communes have } \\
\text { their own natural resource } \\
\text { management systems } \\
\text { Allocation of forest land provides } \\
\text { security of tenure }\end{array}$ & $\begin{array}{l}\text { Weak compliance and poor enforcement } \\
\text { Unfair distribution and conflict (e.g. SFEs vs. local } \\
\text { people at community and household levels; } \\
\text { private sector vs. local people) } \\
\text { Area of land allocated to households is small, of } \\
\text { poor quality and scattered }\end{array}$ \\
\hline Technical & $\begin{array}{l}\text { Policies encompass technical } \\
\text { assistance (training, capacity building) } \\
\text { Government provides technical } \\
\text { guidelines and guidance for forest } \\
\text { plantation activities (e.g. enforced use } \\
\text { of certain species for reforestation } \\
\text { programmes) }\end{array}$ & $\begin{array}{l}\text { People trained are often not those involved in } \\
\text { implementation } \\
\text { Training content and methodology are not } \\
\text { appropriate for local level } \\
\text { Guidelines fail to take into account socio- } \\
\text { economic and ecological characteristics and } \\
\text { traditional knowledge and customary law }\end{array}$ \\
\hline $\begin{array}{l}\text { Benefit-sharing } \\
\text { mechanism }\end{array}$ & Benefit-sharing mechanism in place & $\begin{array}{l}\text { Mechanism is poorly implemented (e.g. } \\
\text { corruption, weak monitoring and enforcement) } \\
\text { Elite capture }\end{array}$ \\
\hline $\begin{array}{l}\text { Implementation } \\
\text { (participation, } \\
\text { involvement, } \\
\text { monitoring) }\end{array}$ & $\begin{array}{l}\text { Policy allows for people to produce the } \\
\text { seedlings suited to their conditions }\end{array}$ & $\begin{array}{l}\text { Local people are 'receivers' rather than 'owners' of } \\
\text { the process } \\
\text { In practice, government agencies provide seeds } \\
\text { and receive funding } \\
\text { Weak monitoring and enforcement }\end{array}$ \\
\hline
\end{tabular}




\subsubsection{National reforestation and afforestation programmes}

As mentioned in the Forestry Development Strategy, Vietnam has made, and will continue to make, considerable efforts to increase forest cover (MARD 2007b). The government of Vietnam has carried out forest rehabilitation programmes since the mid-1950s, with efforts intensifying since the early 1990s. The two national large-scale forestation programmes, namely Program 327 (known as 'Greening the Barren Hills' programme) implemented 1993-1998 and 5MHRP (Five Million Hectare Reforestation Programme, also known as Programme 661) implemented 19982010, have been the most significant initiatives in terms of objectives, size of investment and magnitude of political and international support. Both programmes reflect the state's prioritisation of special-use and protection forests and its commitment to providing state funds for these activities (de Jong et al. 2006). These national programmes have had several positive impacts on the forestry sector, particularly the greening of denuded hills (Sikor and Apel 1998, de Jong et al. 2006), reported as an increase in land cover from 9.3 million ha in 1995 to 12.61 million ha in 2005 , an increase of 0.3 million ha a year (MARD 2007b). However, several problems have also arisen. First, there is limited evidence of the success of these programmes when considering the economic, social and political costs incurred during implementation (de Jong et al. 2006). The longterm effects of forest protection programmes in terms of improved environmental services have not been assessed (Bui et al. 2004). Second, funding for these programmes is often misused (Sikor 1998) or used inefficiently through the allocation of funds to state companies that are no longer economically viable (de Jong et al. 2006). Third, as noted by Nguyen and Gilmour (2000), these programmes promoted a few fast-growing exotics such as eucalyptus, Caribbean pine and acacia. However, due to poor seedlings and inappropriate silviculture techniques applied, these trees had low survival rates. In addition, the 5MHRP was intended only to fund reforestation of protection and special-use forests. Under the programme, the government does not subsidise the reforestation of production forest; rather, economic actors must carry it out for their own benefit, using commercial loans. However, in the past, stakeholders often have had no interest in reforestation because the revenue

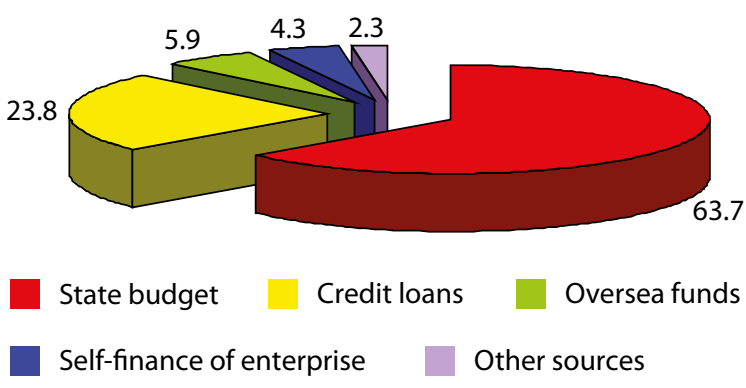

Figure 2.2. Funding sources for 5MHRP

Source: Sunderlin and Huynh (2005), de Jong et al. (2006)

from production forest is not sufficient to cover the annual preferential interest rates of $5.4 \%$ associated with the loans. Finally, forest protection contracts provide low levels of payment that cannot compete with agricultural opportunity costs. Overall, it is difficult to assess the real success of this programme because other initiatives, actors and international projects contributed to these programmes and added significant financial resources (de Jong et al. 2006; Figure 2.2).

Between 1985 and 2000, 80\% of environmental development assistance went to the natural resource sector, predominantly to upland areas (Carew-Reid et al. 1999, de Jong et al. 2006). At least 25 international organisations signed the Memorandum of Agreement for the Forest Sector Support Programme (FSSP), a partnership that was initially established to support the 5MHRP in 1998. This partnership, which still exists, has become a highly useful platform for facilitating the dialogue between government and international donors $^{4}$ (VNFOREST 2011).

On 25 November 2011, the government issued Resolution No. 18/2011/QH13 on Completion of Implementation of Resolution No. 08/1997/ QH10 on the 5 Million Hectare Reforestation Programme. This new resolution regulates that future national budget allocations for forest protection and development will be estimated using the modality of National Target Program on Climate Change Adaptation and Mitigation. Most interviewees viewed Decree 99 and REDD+ as potentially replacing Programme 661 in the future.

4 For more information, see www.vietnamforestry.org.vn. 
Vietnam's experience with these national reforestation programmes (Programme 327 and Programme 661) provide valuable lessons for the implementation of REDD+. For example, past forest management practices based on simple protection principles such as closing off forest areas to increase the area of forest cover and instituting subsidised payments for local people to regenerate and protect these areas with limited product usage rights, proved to be unsuccessful (Doan et al. 2005). Therefore, such approaches should be replaced with intensive 'multiple-use forest management systems' to enhance and maintain the protection function of forests areas in the long term (protection status). In addition, increasing the flow of material and economic benefits to local people will increase their incentive to actively protect forest land (production perspective). This shift in paradigm is reflected clearly in the Forest Protection and Development Law, which provides a firm basis for introducing new types of 'co-management' arrangements between forestdependent communities and local authorities for managing forests (Doan et al. 2005). Given the nature and distribution of forest resources in Vietnam, there will always be large areas of protection forest in the uplands as well as valuable special-use forest, which will need to be managed as a 'public good' in partnership and comanagement agreements with local communities that are dependent on these forest resources for their livelihoods (Doan et al. 2005, Swan 2008, Lai and Vij 2010).

\subsection{Decentralisation}

Traditionally, Vietnam has a strongly hierarchical decision-making system. However, it has also invested significantly in decentralisation, as shown by the case of forest administration.

\subsubsection{Forest management structure}

Forest management is regulated by a legal framework defined by Decree 23/2006/NĐ-CP, which structured forest management into four decentralised levels involving different levels of government agencies and different ministries, mainly MARD and MONRE (Table 2.3).

In general, tasks are divided between the levels as follows:

Central level: The government retains the authority for overall central/state management of forest protection and development nationally, with MARD accountable to the government. Until 2010 , this responsibility was carried out by two specialised agencies created by MARD, namely the Department of Forestry (DoF) and Department of Forest Protection (DoFP). In January 2010, to avoid duplication and to strengthen the workforce, MARD established the Vietnam Forestry Administration (VNFOREST), tasked with advising and supporting the minister in managing the country's forests (Decision 04/2010/QDTTg). MONRE is another key agency, responsible for the implementation of land and forest policies. MONRE is in charge of land administration while MARD is in charge of forest management.

Table 2.3. State management system for forest resources and forest land in Vietnam

\begin{tabular}{lll}
\hline Level 1: Centre & $\begin{array}{l}\text { Central government } \\
\text { Ministry of Agriculture and Rural Development (MARD) } \\
\text { Director General of the Vietnam Forestry Administration } \\
\text { (VNFOREST) }\end{array}$ & $\begin{array}{l}\text { Ministry of Natural Resources } \\
\text { and Environment (MONRE) }\end{array}$ \\
\hline Level 2: Province & $\begin{array}{l}\text { Provincial People's Committee (PPC) } \\
\text { Department of Agriculture and Rural Development } \\
\end{array}$ & $\begin{array}{l}\text { Division of Forest Protection } \quad \text { Division of Forests } \\
\text { Resources and Environment }\end{array}$ \\
\hline Level 3: District & $\begin{array}{l}\text { District People's Committee (DPC) } \\
\text { Forest Protection Stations } \quad \text { Division of Agriculture and } \\
\end{array}$ & $\begin{array}{l}\text { Rural Development } \\
\text { Division of Natural Resources } \\
\text { and Environment }\end{array}$ \\
\hline Level 4: Commune & $\begin{array}{l}\text { Commune People's Committee (CPC) } \\
\text { Forest and agricultural staff }\end{array}$ & Land management staff \\
\hline
\end{tabular}


Provincial level: The Provincial People's Committees (PPCs) undertake state management of forest development and protection in their localities. PPC chairpersons are accountable to the Prime Minister in relation to the management of all state forest resources and forest areas in their localities (provinces and cities). Provincial units of MARD, called Departments of Agriculture and Rural Development (DARDs), contain a forestry section to assist the PPCs in carrying out their duties.

District level: District People's Committees (DPCs) undertake state management of forest development and protection in their localities/ district areas. DPC chairpersons are accountable to the PPCs for cases of forest damage or loss in their localities. DPCs appoint Divisions of Agriculture to carry out their tasks. Each division is allowed to employ one or two forest staff members responsible for monitoring forestry activities.

Commune level: Commune People's Committees (CPCs) undertake state management of forest development and protection in their localities/ communes. CPC chairpersons are responsible to the DPCs for any mismanagement of forest causing damage or loss of forest cover. Communes appoint special forest staff to carry out their tasks. Although the Forest Protection and Development Law stipulates that communes in areas with forest cover must recruit forest staff, budget constraints mean that most communes have not done so (de Jong et al. 2006).

Below the commune is the informal system led by the heads of the villages. Heads of villages are important intermediaries between national laws and existing customary law. In many studies (e.g. Pham et al. 2009), the level of activity of these groups is seen as a key determinant of the success or failure of reforestation programmes.

Also outside the legal hierarchy is the extension service meant to help forest owners to manage their resources. Extension is provided not only by the state forestry extension system, but also by the State agencies, non-state forestry enterprises and international forestation projects. Indeed, most forestry extension services implemented by these other agencies are much better than the state's service (de Jong et al. 2006). Voluntary forestry extension organisations at the local level have gradually been set up under the control of social and professional associations (de Jong et al. 2006; Figure 2.3).

As stated above, until the early 1990s, SFEs traditionally played an important role in the forestry sector and the livelihoods of the many people living in their areas of control. Forty per cent of forest land was controlled by SFEs in the 1990s. In line with other reform efforts, SFEs underwent restructuring to separate public and private functions and transform the remaining SFEs into autonomous, commercially viable businesses based on principles of sustainable forest management (EASRD technical note 2005, Decree $2000(2004)^{5}$, Artemiev 2003, World Bank 2003). The reform led to a significant reduction in the numbers of SFEs, with those deemed not to be generating any benefits replaced by another form or dissolved (Sunderlin and Huynh 2005, Jong et al. 2006). Nevertheless, although no reliable, upto-date national statistics on SFEs are available, MARD indicated that, as of May 2005, some 362 SFEs remained of the 370 SFEs operating in 2002.

The reform of state-owned enterprises (SOEs), which influenced the reform of SFEs, took place in three stages (see Table 2.4). Although the reform was initially expected to result in a major release of land to households, in most provinces, SFEs retain control over much of the forest land and continue to use resources inefficiently.

Following the government reform of SOEs, MARD and the Ministry of Finance issued Joint Circular 109 to implement Decision 187, in which the government's intention was to reform SFEs

\footnotetext{
5 The objectives of Decree 2000 include: 1) to use land and forest resources more efficiently and sustainably; 2) to enhance the business and production efficiency of SFEs; and 3) to improve economic and social opportunities in SFE areas. The decree is founded on the principle of separating the public interest from commercial activities. SFEs that carry out mainly business and production activities are required to operate under the market system. SFEs whose activities are mainly related to the public interest must be made into protection forest management boards. The decree notes that the state will fund only the investment required for special-use and protection forests, and SFEs that incurred business losses for more than three years, or those that did not warrant being turned into service units, were dissolved.
} 


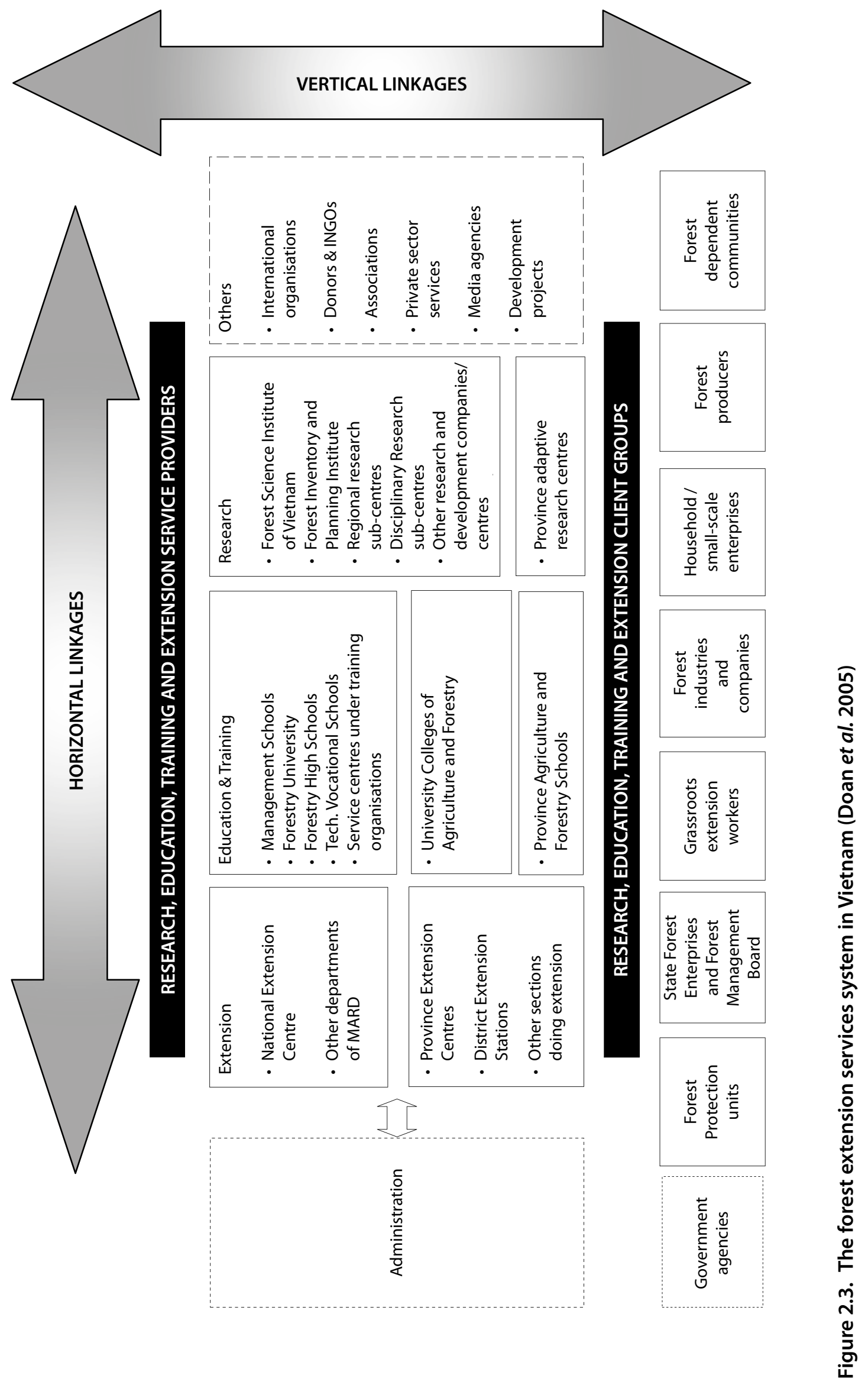


through a clearer separation of the government's 'public good' and business activities.

Although the system clearly shows government support of decentralisation, four issues emerged as key challenges for its implementation. First, capacity among government officials to perform the task is limited (UN-REDD and MARD 2010). Although this decentralised system gives PPCs and DPCs the authority to allocate forest land use rights to organisations, households, communities and individuals, as Pham et al. (2008) highlighted, some either lack the confidence to fulfil this role and look to the central government for guidance. Second, although forestry extension in Vietnam is set up at all levels, the small number of forestry extension workers is insufficient to address actual needs (de Jong et al. 2006). Third, institutions within Vietnam's forestry sector are heavily influenced by the political legacy of centralised decision-making. This resulted in widespread use of forest rehabilitation funds for other purposes under the national reforestation programme (de Jong et al. 2006). Fourth, ineffective coordination and conflict between the vertical and horizontal levels has created problems in the management of forest resources (Pham 2009). Moreover, although use rights have devolved to stakeholders outside the state, these stakeholders have no real decisionmaking power over the use of the land because

Table 2.4. Restructuring of state-owned enterprises in Vietnam

\begin{tabular}{lll} 
& & \\
\hline 1990-1993 & 1994-1997 & 1998-present \\
\hline $\begin{array}{l}\text { Focus on } \\
\text { reorganising }\end{array}$ & $\begin{array}{l}\text { Focus on } \\
\text { reorganising }\end{array}$ & $\begin{array}{l}\text { Focus on } \\
\text { speeding up the } \\
\text { privatisation }\end{array}$ \\
$\begin{array}{l}\text { strengthening } \\
\text { business and }\end{array}$ & $\begin{array}{l}\text { enterprise } \\
\text { associations }\end{array}$ \\
production in & to establish & \\
the SOE sector & general & \\
(Decision 315/ & corporations & \\
HDBT, Decree & and to & \\
388/HDBT) & transform SOEs \\
& into joint-stock \\
& companies \\
& (Decision \\
& 90/TTg, \\
& Decree 28/CP) \\
\hline
\end{tabular}

Source: EASRD (2005)
MARD and MONRE are the key actors (Nguyen et al. 2008).

\subsubsection{Tax reductions and financial decentralisation}

In Vietnam, the National Assembly allocates funds from the central budget to all ministries, other government agencies and provincial and municipal governments. These government agencies are responsible for collecting and spending revenues, in accordance with guidelines set out in the Law on the National Budget. The Ministry of Planning and Investment (MPI) coordinates and allocates the budget and prepares sectoral plans for the nation; the Ministry of Finance (MoFi) establishes financial norms related to all transactions. The provincial authority decides on the division of duties and decision-making powers in relation to collecting and spending revenue at the district and commune authority levels.

The main law related to taxation and natural resources is the 2009 Law on Taxation of Natural Resources; details and instructions on implementing the law are contained in Decree No. 50/2010/NĐ-CP, 14 May 2010. The various pieces of legislation related to land use and taxation are outlined in Table 2.5.

The Law on Taxation of Natural Resources specifies the tax rates for 10 types of natural forest products. These rates range from $5 \%$ to $35 \%$ for each defined group of forest products (e.g. log groups of various sizes for each of branches, roots and treetops; fuelwood; bamboo; reeds; aloe wood; anise; cinnamon; cardamom; and other natural forest products). Forest products exempt from tax are branches, treetops, fuelwood, bamboo, reeds and aloe extracted legally by individuals to meet their own needs. The National Assembly Standing Committee decides details of tax exemption on a case-by-case basis.

Organisations and individuals that replant fallow land and denuded hills are entitled to a preferential tax in accordance with the Law on Investment Encouragement. When timber from regenerated natural forest is sold, the natural resource tax is not levied. When forest products from plantation forest are sold, the business tax is not levied (de Jong et al. 2006). 
Table 2.5. Key pieces of Vietnamese legislation on land use and taxation

\begin{tabular}{lll}
\hline Type of tax & Relevant law & Collecting agency \\
\hline $\begin{array}{l}\text { Taxes on natural resources } \\
\text { except for oil and gas }\end{array}$ & Decree 05/2009/NĐ-CP & Local authority \\
Tax on land transfers & Law on Taxation of Natural Resources (2009) & \\
Tax on agricultural land & Law on Tax on Agricultural Land Use; & Local authority \\
& Resolution No. 15/2003/QH11 & \\
\hline
\end{tabular}

By the end of 2003, the National Assembly had promulgated a policy exempting and reducing the agricultural land use tax for farmers engaging in forest rehabilitation. Under this policy, households that established forest plantations and owned an allocated area of less than 30 ha were exempt from the agricultural land use tax, and other economic organisations that managed forest plantations were entitled to a $50 \%$ tax reduction. This tax exemption and reduction were in force from 2003 to 2010 . The policy encouraged organisations, households and individuals to actively participate in the 5MHRP, particularly in the plantation of 2 million ha of production forest (de Jong et al. 2006).

\subsection{Forest land tenure and ethnic minorities' rights to forests, land and carbon}

Vietnam has made great progress in devolving control over forest and forest resources to local communities. Because of the importance of issues of tenure and rights in discussions on the implementation of forest management in general and REDD+ in particular, the topic is addressed in this separate section rather than being considered as part of the decentralisation discussion.

\subsubsection{Forest land allocation}

About 25 million people in rural Vietnam live in and around forests and, to some degree, depend on forests for their livelihood (RECOFTC 2011). Most forest-dependent people are members of the ethnic minority groups that live in forested and remote upland areas (Sunderlin and Huynh 2005, Nguyen et al. 2008). However, rights to forest resources are still far from secure and poverty rates remain high (UN-REDD 2008). The forest land allocation (FLA) process was expected to alleviate these problems.
Forest and forest land allocation policies have been implemented since 1983 (through Decision No. 184) and were further strengthened by the Land Law (Decree No. 02/CP on forest land allocation) and the revised Land Law of 2003. The Land Law defines the rights of land users in terms of land use, transfer, concession, lease, mortgage and contribution of capital on the basis of land value. Although all land is administered by and comes under the authority of the state, the law states that land users can be allocated up to 30 ha of forest land in production and protection forests for up to 50 years. The state can also lease forest and forest land to other economic sectors for business and production purposes. Specialuse forests are managed by state agencies (e.g. the management board).

Progress in forest land allocation has been slow. This is attributed partly to the reassignment of forest land allocation responsibilities from MARD to MONRE, which lacked the necessary human and financial resources, and partly to the strict conditions for allocation and lack of interest among households because agriculture production generated more income than forest land (Sikor 1998, 2001, de Jong et al. 2006). Moreover, the implementation of the FLA policy was constrained by many factors, as follows:

1. Difficult terrain, limited funds and personnel to carry out the proper demarcation needed to issue Red Books (land use right certificates), out-of-date land use maps and unclear boundaries between land categories resulted in many forest land certificates not matching the area managed because different authorities use different data or methods to measure the area (Le 2010).

2. The gap between national law and traditional land use practices as well as poor enforcement of regulations impede the effective 
management of forests (Doan 1998, Tran 2000). These issues have been recognised but not adequately addressed.

3. Forest land allocation does not guarantee custody by a 'real owner' (i.e. a legal entity) and might in fact create open access conditions. Allocated forest land is often infertile and, in the absence of financial and technical support from the government, lands are often simply abandoned (Doan 1998). More seriously, land classified by the government as 'unused' is in fact under customary tenure not formally recognised by law (Nguyen and Gilmour 1999). In many places, no family wanted the allocated forest land because its distance from houses made it difficult to manage and protect (Donovan et al. 2007). In these situations, households might rent the land to an SFE for a fee as low as the land use tax ( $\mathrm{Vu}$ 2001). In other cases, households do not want to invest in the forest land because they fear the state may reclaim the land for forest plantations at short notice (Nguyen 2001).

4. FLA does not permit joint ownership at the household and community levels. This tends to limit the rights of women and undermine upland production systems that are based on joint property approaches (MARD/ICD 2001: 53).

5. At the provincial level, forest land use changes take place quite regularly; this prevents households from adjusting their own plans to cope with the sudden changes (Nguyen 2001). As a result, land is left unused or is used for purposes other than those specified. In Vietnam, only $20-30 \%$ of the land area allocated was developed in accordance with the government's land use plan (Morrison and Dubois 1998).

6. Local people rarely view the commercialscale harvesting of timber of benefit to them, rather, it often erodes traditional resource management systems (Apel 2000). FLA does not seem to support poverty reduction because income from forest protection and tree planting rarely contributes to the household income of the rural upland poor (Nguyen et al. 1999, ADB 2000). State and logging enterprises tend to view large trees as their own assets and not those of forest dwellers.
7. Different authors have made different assessments of the impact of land and forest allocation for households and groups of households. Helvetas Vietnam (2002) claimed that FLA had a positive effect on poor farmers. Nguyen et al. (2008), on the other hand, claimed that households and communities did not gain any actual control over local forests: they still continue to seek permission from the relevant agencies to fell trees and use forest land, and they often have limited understanding of their rights and duties.

8. According to Decision No. 187, SFEs are required to allocate and contract forest land under their control to third parties for longterm use or protection, in accordance with Decree No. 01 CP; these contracted third parties then can benefit from the main forest products. However, in practice, SFEs often contracted third parties on an annual basis rather than a long-term basis (de Jong et al. 2006). This led to low commitment of households in forest protection.

9. The most critical problem is inequity, with land preferentially allocated to mass organisations, employees of SFEs and certain individuals. Hence, forest land has become the basis of capital accumulation for households that have access to political power and social networks (Rambo and Le 1996, ADB 2001). Inequity between ethnic groups also occurred, with Kinh groups often receiving more land than other ethnic groups (Pham 1999). This widened the gap between rich and poor and reinforced the existing elite in the community (Rambo and Le 1996, Hobley et al. 1998, Huynh 1998).

10. On the one hand, FLA has allowed the involvement of various non-state actors in forest management activities. Currently, there are eight stakeholder groups: state-owned companies (formerly SFEs); protection forest management boards; management boards of special-use forests such as protected areas and national parks; individual households; village communities; people's committees (PCs); joint ventures; and the army. On the other hand, state companies and management boards continue to manage more than $50 \%$ of the country's forests. Households manage $18.4 \%$ and communities only $1 \%$. PCs continue to 
manage a large proportion (20\%) of natural forest (Hoang et al. 2010). Thus, local people still have only limited access to protection and production forest. In fact, only a small proportion of land has been allocated to households and communities $-29 \%$ and $1 \%$ of the total production forest, respectively (Tebtebba 2010).

11. In general, state actors own the highest-quality forests, while non-state actors, particularly local people, have mostly been allocated poorer-quality and degraded forests (Nguyen et al. 2008). Hoang et al. (2010) suggest that this may mean that future REDD+ funds might be retained at the government level, with only very limited payments made to the actual managers of the forest. This also implies that difficulties will arise in relation to involving households in planning activities, in monitoring, reporting and verifying, and in receiving and managing rewards - aspects that are integral to the long-term effectiveness of REDD+.

\subsubsection{Forest user rights}

Land certificates ('Red Books') provide forest land users with the rights to use, transfer, release, inherit and mortgage land - rights that constitute an important condition for participation in REDD+. The challenge lies in fully informing local people, especially the poor, about their rights, how to access the land and how to derive full benefits under such policies and laws as FLA, forest protection and forest plantation programmes. In reality, most ethnic minority households have yet to take full advantage of the policies. This is a difficult social problem to solve; it also poses challenges for REDD+ design and implementation (Tebtebba 2010).

Moreover, land allocation in Vietnam has been based on the ability to invest in the land, with labour and capital. However, most poor people, including the ethnic minorities that comprise the majority of forest-dependent people lack both labour and funds. The policy therefore often excluded them from receiving a larger share of the land allocation (Dinh 2005). Furthermore, as RECOFTC and ASFN (2010) highlighted, civil society in Vietnam is relatively weak, which makes it more likely that the rights and interests of indigenous people may be overlooked. Research on the gap between national and customary laws remains limited; the attention paid to indigenous knowledge is generally inadequate. As a result, national forestry policies are impractical and are generally ignored in remote areas.

On the other hand, Vietnam, acknowledging the importance and rights of indigenous people, was the first country in the world to conduct a Free, Prior and Informed Consent (FPIC) process under the UN-REDD programme. FPIC is part of the United Nations Declaration on the Rights of Indigenous Peoples (UNDRIP), which Vietnam ratified in 2007. A pilot FPIC process was conducted in Lam Ha and Di Linh Districts, Lam Dong Province, in 2010, with a positive reception from the government and donors (Nguyen $e t$ al. 2010). Nevertheless, there is still need for improvement with more time devoted for internal discussions among villagers, better explanation of national legal frameworks and programmes as part of the provision of information, and the creation of a grievance and review mechanism, independent of the FPIC team, to ensure any complaints by local people are heard (RECOFTC 2011). Other challenges for implementing FPIC as part of REDD+, as highlighted by UN-REDD and MARD (2010), include how to communicate the potential benefits of REDD+ in an understandable way without engendering false expectations regarding those benefits.

\subsubsection{Carbon rights}

The expectation of financial incentives for achieving emission reductions has led to a formal debate on 'carbon rights' at global and national levels. In Vietnam, discussions are still in their infancy and are strongly driven by the private sector. Two recent meetings of the national REDD+ subtechnical working group on private sector engagement (held in September and December 2011) were devoted to this topic and involved both an international company (ForestFinance) and a national company (Truong Thanh).

As expected, the debate reveals a power contest between layers of government. The interaction of 'carbon rights' with existing or emerging rights, authorities and power over land use decisions is not 
easily understood. It remains unclear who owns carbon and carbon credits in Vietnam.

USAID (2011) suggests three ways to legalise carbon rights: explicit, ${ }^{6}$ implicit $^{7}$ and contractual rights. ${ }^{8}$ Current debate and government statements appear to indicate that the government intends to adopt a mixture of implicit and contractual rights. The contractual relationship could prove beneficial if it is transparent and the service providers - often the poor and disadvantaged - have the knowledge, understanding and capacity to protect their rights. However, there is a lack of clarity regarding the contractual terms underpinning the trade in carbon rights and associated liabilities.

Currently, government entities, including forest enterprises, forest companies and management boards, manage 8 million ha of forest in Vietnam (mainly special-use and protection forests), with only 3 million ha allocated to local households. Investors in the voluntary carbon market tend to concentrate on special-use and protection forests (mainly natural forest) in collaboration with management boards and SFEs, which manage these kinds of forest, rather than with local households, whose land area tends to be fragmented. However, as the management boards and SFEs are fully government funded and therefore are not profit-oriented, they are not eligible to enter into a commercial carbon deal. As a result, any collaborations in relation to forest carbon between management boards/state forest companies and carbon investors are not legally recognised. This triggers investment risks for the investors and leads to a lack of clarity regarding potential future mechanisms for sharing benefits (if there are any).

Although most stakeholders in Vietnam are still unclear as to whether carbon rights should be perceived as a commodity or a right, the private

6 Where the law specifically defines the rights and responsibilities relating to sequestered carbon or reduced deforestation.

7 Derived from existing laws or existing rights that do not specifically mention carbon rights by name, but nonetheless could govern rights to benefit from carbon sequestration or reduced deforestation.

8 Arising through particular agreements between parties that are enforceable under existing national contracts or administrative law. sector in Vietnam is promoting a view of carbon rights as associated with land use rights and is advocating for a legal framework that supports such rights. The government has acknowledged that there are gaps in the legal framework but prefers to take a cautious approach by piloting several schemes before formally legalising carbon rights.

The 2003 Land Law defines in detail the rights to possess, manage and use land. According to the law, the land and natural resources belong to the 'people' as a whole and are managed by the 'state' on their behalf. The state, therefore, has exclusive management and decision-making rights over natural forest; it then designates, leases or recognises the use of land, and allocates these rights to the people. Therefore, the state can regulate any benefits and profits generated from natural forest, including carbon rights. In principle, this means that forest owners will have the right to receive the value added from carbon payments from the point where they are allocated land. For example, carbon credits are purchased for the period of 1990-2010 while the forest owners (households, communities, SFEs, private sector) were allocated land in 2005. In this case, the forest owners will receive forest carbon payment for the period 20052010, and payment for the period of 1990- 2005 will be paid to State budget or other actors who previously managed this land. However, the state can still regulate part of this payment via taxes or fees. Also in principle, forest owners should be able to transfer their carbon rights, although current regulations do not give this right to owners of natural forest.

It is important to point out the details relating to production forest, as set out in the Forest Protection and Development Law, as follows.

- In cases where forest owners invest their own money in planting, tending, nurturing and protecting forests, they shall be entitled to decide on the exploitation of planted forests. Products from forests planted by forest owners may be freely circulated on the market. If planted forest trees yield precious or rare timber, the exploitation thereof must comply with Government regulations;

- In cases where forests are planted using funds from the State budget, forest owners 
must compile exploitation dossiers and submit them to relevant agencies to verify and approve. Products harvested from forests planted by forest owners may be freely circulated on the market. If planted forest trees yield precious or rare timber, the exploitation thereof must comply with Government regulations;

These provisions mean that the government retains decision-making control over the carbon in forests planted using government funding, whereas investors retain the carbon rights for forests planted using funds from private investment.

Those that might benefit from carbon rights may be classified into two groups: direct beneficiaries (organisations, households and individuals and communities that have leased or been allocated natural forest by the state and those who are contracted by government agencies to protect forests) and indirect beneficiaries (local communities that live around forests but that might not directly manage them).
The process of defining carbon rights involves many parties, as the production/conservation of carbon can be seen as a value chain, each step of which involves a variety of rights, authorities and powers. The combination of their decisions results in a definition of 'carbon rights'. Some steps involve existing rights and regulations related to land use and land use change, whereas other elements are new. This view of the process is consistent with the framework proposed by van Noordwijk et al. (2010) and adapted in Figure 2.4.

As shown in Figure 2.4, a large number of actors are involved in producing and conserving forest carbon at various levels and scales; the result is a series of complex relationships and negotiation processes to control the final product - carbon credits. Existing rules must be complemented by new rules, decided and influenced by national REDD+ strategies, Locally Appropriate Adaptation and Mitigation Actions (LAAMA), Nationally Appropriate Mitigation Actions (NAMA) and Globally Appropriate Mitigation Actions (GAMA). Stakeholders must be concerned not only with

\begin{tabular}{|c|c|c|c|c|c|}
\hline Right to & Plot & Village & Landscape & Country & Global bodies \\
\hline \multirow{2}{*}{$\begin{array}{l}\text { 1. Modify carbon stock } \\
\text { (harvest timber, plant } \\
\text { trees, prevent fires etc.) }\end{array}$} & \multicolumn{5}{|c|}{ Land use rights and tenure rights } \\
\hline & \multicolumn{5}{|c|}{$\begin{array}{l}\text { Land use planning and reduction of rights-related } \\
\text { conflicts }\end{array}$} \\
\hline $\begin{array}{l}\text { 2. Measure (reduce } \\
\text { uncertainty regarding } \\
\text { amount of } C \text { stock) }\end{array}$ & & & MRV & MRV-inst & \\
\hline $\begin{array}{l}\text { 3. Set REL standard } \\
\text { (establish baseline/ } \\
\text { additionality) }\end{array}$ & & & LAAMA & NAMA & GAMA \\
\hline 4. Determine leakage & & & & NAMA & \\
\hline $\begin{array}{l}\text { 5. Eligibility filter (define } \\
\text { eligibility of emission } \\
\text { reduction claim) }\end{array}$ & & & & & REDD+ safeguards \\
\hline $\begin{array}{l}\text { 6. Negotiate price or } \\
\text { investment regime }\end{array}$ & & & & & Fund-based \\
\hline $\begin{array}{l}\text { 7. Impose tax and/or co- } \\
\text { invest public funds }\end{array}$ & & & & & \\
\hline
\end{tabular}

\section{Figure 2.4. REDD+ value chain}

Notes: MRV = Monitoring, Reporting and Verification; LAAMA = Locally Appropriate Adaptation and Mitigation Actions; NAMA = Nationally Appropriate Mitigation Actions; GAMA = Globally Appropriate Mitigation Actions 
their own activities, but must also respect others' rights. However, how agreements will be reached and what aspects need to be considered remain important questions. The current global framework and Vietnam's legal frameworks, although providing clear and detailed guidance on the rights to modify carbon stocks, are still underdeveloped.

\subsubsection{Legal provisions for household and community management of forests and the connection to poverty reduction}

Currently, 23\% of Vietnam's communes are classified as poor. This is equivalent to $50 \%$ of the total natural area, $66 \%$ of which is forest land. Until the 1960s, community-level management of forests and natural resources was common in the remote uplands. However, in the 1960s, centralised state control of forests was introduced and agriculture cooperatives replaced existing communities. As a result, local norms and rules have disappeared from some areas. Beginning in 1991-1993, the strong state control of forests was rescinded, and households were designated to replace SFEs as the managers of natural forests (Sikor and Apel 1998). The Forest Protection Development Law of 1994 demonstrates the national government's willingness to support community forestry and its intention to address two major problems. The first problem was the failure of exogenous models of community forestry in areas where the process of collectivisation dismantled indigenous norms and systems of organisation and undermined local authority, thus restricting villagers' capacity to manage forests effectively (Gilmour 1998). The second problem was that the termination of extraction quotas for almost all SFEs encouraged illegal logging, thus potentially undermining the revenue base for community forestry regimes (Sunderlin and Huynh 2005). Furthermore, the national reforestation programme, which involved restriction of marginalised communities' access to forests and turned them into hired labourers in the forestry sector, put these communities into further poverty. Community forestry has the potential to increase use of forest resources at the village level and, through benefit sharing, to increase the community's share of that larger amount.
The 2003 Land Law and the Forest Protection and Development Law improved the situation by allowing the allocation of land (including forest land) to communities, and not only to households; this change in the law represents a shift in the legal basis for community forestry in Vietnam.

\subsubsection{Participation in decision-making processes}

The government has acknowledged, through the National Forestry Development Strategy, the Forest Protection and Development Law and other related policies, that the success of the forestry sector depends on the participation of all stakeholders. Article 20 of the Forest Protection and Development Law stipulates the following requirements for the publication of forest protection and development plans:

Within 30 days after approval by the relevant State agencies, forest protection and development planning and plans must be published according to the following stipulations:

- The People's Committees at all levels shall publish forest protection and development planning and plans of their respective localities;

- Forest protection and development planning and plans shall be published at the People's Committees' offices throughout their effective period.

Moreover, the Ordinance for Grassroots Democracy sets out mechanisms for stakeholder participation and consultation.

However, as revealed through our interviews, the design of these mechanisms does not encourage genuine stakeholder participation. Social organisations, including local and international NGOs and non-state sector associations, are invited to take part in policymaking but their participation is limited to dialogue rather than actual decision-making (Le 2010). In practice, there is no transparency in local authorities' operations and participation is almost nonexistent. A recent study by Boissiere et al. (2009) showed that local people are willing to participate 
in the monitoring and control of forests and in the selection of local species for reforestation programmes, but they lack access to the necessary information to be able to participate meaningfully.

Furthermore, $90 \%$ of our key informants agreed that most planning and participation processes related to forestry in Vietnam are sectoral, and hence are without cross-sectoral collaboration or integration of interests. Wider consultation, such as with the private, mining, industrial, commercial and trade sectors, is poor or non-existent. Most consultation on national policies concentrates only on seeking information and feedback on traditional stakeholders. This viewpoint is supported by studies by Bui et al. (2004), Sunderland (2005), Sunderlin and Huynh (2005), Thomas et al. (2008) and Pham et al. (2009), all of which observed weak involvement of the poor in the development of environmental policy, and topdown policy design, with low participation of local people in policy implementation.

Although several PES schemes are operating in Vietnam, most were developed with little involvement by or consultation with the poor. Even where intermediaries appeared to support disadvantaged groups, these intermediaries either did not employ appropriate participation tools or carried out the consultations poorly because of time constraints (Pham et al. 2010) and the limited capacity of local people to use their approaches (Thomas et al. 2008). A transition from top-down land use plans to participatory, problem solving-oriented land use plans could potentially enhance local decision-making in poor communities vis-à-vis other stakeholders. Operational shifts are needed to improve resource management programmes, including governance reform, decentralisation of planning and improvement of revenue-sharing mechanisms, as well as the adoption of pluralistic approaches to decision-making.

Furthermore, although the current SocioEconomic Development Strategy (SEDS) and Socio-Economic Development Plan (SEDP) do acknowledge the need to involve CSOs and local communities in climate change policy implementation and supervision (see Chapter 3 for further details), these plans do not set out the measures needed to ensure such involvement. Neither do the plans mention or describe any strategies to ensure the disclosure of environmental information or the role of public participation in environmental management and monitoring. So far, CSOs and local communities have had minimal involvement in or influence over the climate change agenda. A major criticism of the NTP is that it is very top-down in its design and lacks tools for involving local communities.

\section{Gender}

Gender and forest management are closely related in the context of Vietnam (Dinh 2005). However, most available studies show that women have minimal participation in the forestry sector, and there is no evidence of effective collaboration between local authorities and women in the communities. Women have not been encouraged to participate in sustainable forest management, in part because of the lack of a proper policy mechanism to ensure livelihoods and people's capacity to meet daily needs, especially in relation to land use rights and benefit-sharing schemes (Hoang 2006).

Other problems are the shortage of staff trained in ways to integrate gender into forestry activities and the fact that women are rarely appointed to leadership positions (Hoang 2006). Women in ethnic minority groups in the Central Highlands show a serious lack of awareness of options provided by the land allocation policy (e.g Land Law 2003 and Forest Protection and Development Law 2004). Indeed, most local people in general have little understanding of their rights and responsibilities associated with forest protection contracts with management boards or SFEs.

Despite its importance, the issue of representation has received little attention either in research or in policy-making processes. Most research on gender and forestry (e.g. Duc 2005, Hoang 2006) assumes that Vietnamese women comprise a homogeneous group and therefore tends to make general recommendations without recognising that even a single community may include three or four ethnic groups, each of which has its own cultural values, beliefs, rights and access to the pertinent resources. A particular concern is poor women's limited access to markets for NTFPs, especially as returns to labour increase, technologies become more sophisticated and processing facilities become more centralised (Neumann and Hirsch 2000). 


\section{Political and economic context of deforestation and forest degradation in Vietnam}

$\mathrm{T}$ This chapter analyses REDD+ from a political economy perspective, including an overview of macroeconomics, the political system and reforms during recent decades. We begin with a brief overview of the country's political system. We then explain the general decision-making processes linked with decision-making bodies, including political parties, parliament, ministries and communes, and examine the system's strengths as well as problems that may arise from it. We then discuss economic development and its impact, particularly in relation to hydropower development and woodprocessing industries. In particular, this chapter focuses on the cause-effect linkages between changes in the political economy, deforestation and forest degradation processes and REDD+related decisions.

\subsection{Historical overview of Vietnam's political system}

Vietnam is one of the very few countries in the world that has retained a socialist political regime while having implemented reforms to create a more market-oriented economy. The historical pathway of the changes is set out in Figure 3.1 (Fforde 2000). Historical records examining the changes in the political economy are scarce, with Dutt et al. (2004) being one of the very few attempts. As discussed in previous chapters, however, there is a widening gap between the government's stated aims and the actual policy choices and outcomes (Abonyi 2002).
Before 1986. Until 1945, private ownership was the norm in Vietnam. However, during 19581960, the State appropriated most private land. Until the 1970s these lands were allocated this land to cooperative farming units and state enterprises. The 1980 Constitution stipulated that the state had ownership of all land in the whole country. Land allocation was regulated and implemented through the central administrative mechanism rather than the market (Nguyen and Kammeier 2002) (see Chapter 2 for further detail).

1954-1985. During this period, (North) Vietnam instituted a centrally planned economy, through which resources were directly allocated into national development priorities to eradicate capitalist economic forms and to set up a system based on state-owned enterprises and collectives. This system of central planning was adopted in the South after reunification (Nguyen and Kammeier 2002). However, during this period, the state enterprises were run inefficiently (Nguyen and Kammeier 2002).

1986-1989. In 1986, Vietnam adopted a new policy, commonly known as Doi Moi ('Reform'), which aimed to overcome obstacles to social and economic development caused by subsidies and central planning. The country shifted from a command economy with centralised planning to a more decentralised transitional economy, in which allocation of resources is determined by a mix of market mechanisms and central state control. Before 1986, non-state domestic investment 


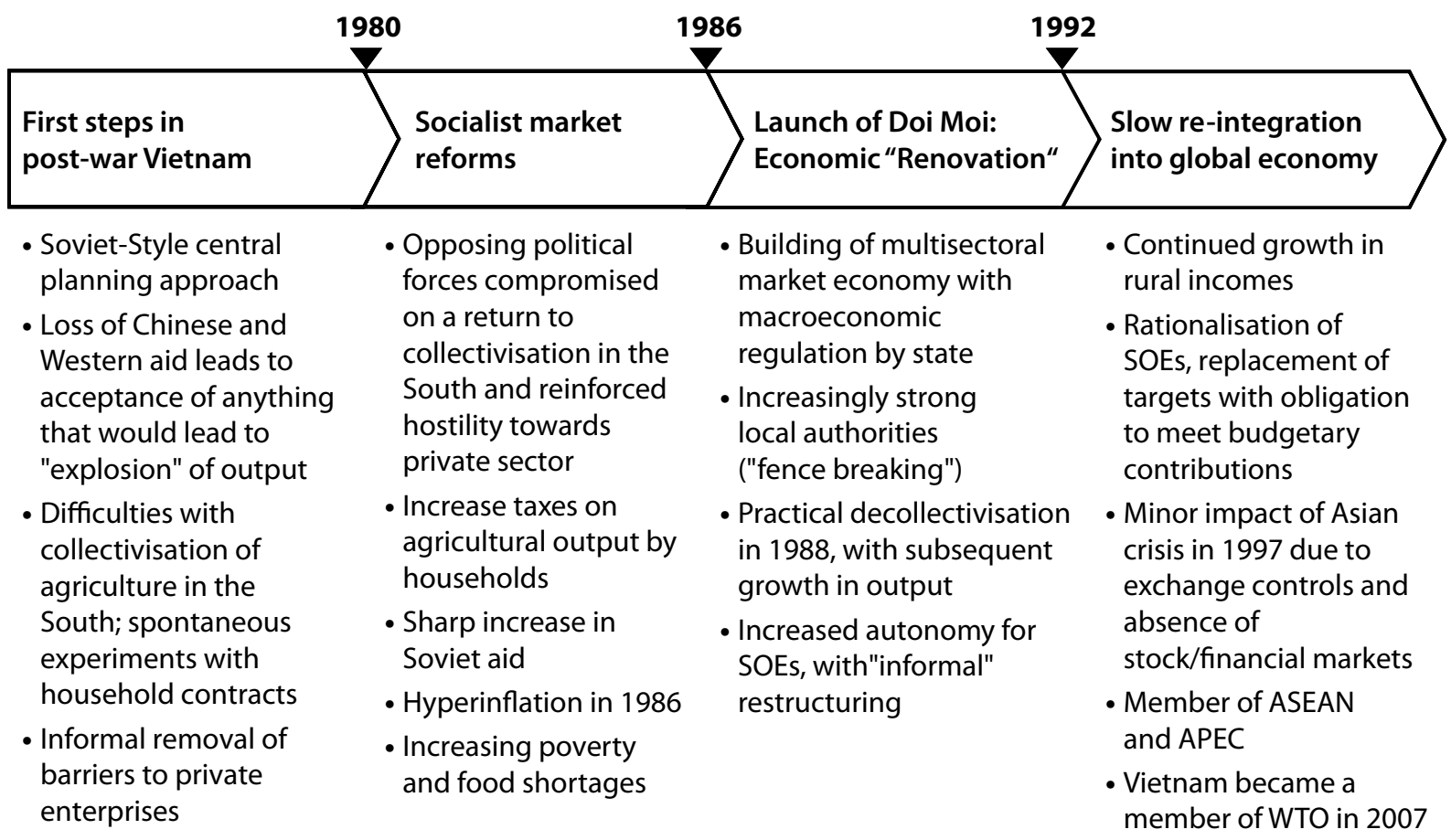

\section{Figure 3.1. Overview of economic and political developments since the Vietnam War (Adapted from} Dutt et al. 2004)

accounted only for $2 \%$ of GDP or $15.5 \%$ of the total investment whereas state investment dominated the total investment and accounted for $10.9 \%$ of GDP (World Bank 1990). By 1997, the non-state sector (including local and foreign sources) accounted for $64 \%$ of total investment while the contribution from the state-owned sector had been reduced to only $36 \%$ of the total (GSO 2000).

1989-onwards. From 1989 to 1995, Vietnam's economy experienced an annual growth rate of $8 \%$ (UN 2007). The country and its economy became increasingly outward-oriented, driven by investment and exports. Exports contributed more than $65 \%$ of the country's GDP in 2008, with the USA, the EU, Japan and Australia as its biggest export markets. Vietnam is now shifting from its status as an aid recipient towards becoming a middle-income country (Forsberg 2011).

The year 1996 was marked by the release of the Budget Law, which created a framework for provinces to increase their own revenue base, replacing their previous heavy reliance on grantsin-aid and transfer payments from the central government. Provincial governments were allowed to set rates and collect fees (or user charges) for the public services that they provide (Nguyen and Kammeier 2002).

Between 1988 and 1993, Vietnam stabilised its macroeconomic conditions by applying the classic tools of interest rates, domestic credit, fiscal policy and exchange rate management. Dollar and Ljunggren (1997) emphasised that this adjustment was made without any significant international financial aid, from either the International Monetary Fund (IMF) or anyone else. However, the country encountered problems in dealing with overspending in the public sector, which had been financed by a combination of Soviet aid and money printing. Dutt et al. (2004) argued that with external debt in 2002 already at $42 \%$ of GDP, Vietnam did not have much room for fiscal policy; indeed, the country still has limited tax collection ability. SOEs contribute much more than the private sector in taxes and tax collection is difficult.

Doi Moi is seen as the most significant driver in the development history of Vietnam (Fforde 2000, 2004, Nguyen and Kammeier 2002, Chu and Dickie 2006, Forsberg 2011). This policy made 
it possible for Vietnam to overcome its economic crisis, control inflation, stabilise macroeconomic conditions, boost foreign and private investment in the national economy and achieve the highest and most sustainable economic growth since the war ended in 1975 (Fforde 2000). This policy also shifted the country from collectivisation to a household responsibility system, which created great incentives for farmers. As a result, agricultural production has increased tremendously since 1990 , and the country is now the third largest rice exporter in the world after Thailand and the United States (UN 2007); furthermore, its average annual economic growth rate has consistently been above $7 \%$ for the past two decades. The contribution of agriculture to GDP is shown in Figure 3.2; as shown, the basis of the economy is shifting from agriculture to industry and services. However, according to the World Bank (2010), rural households make up more than $72 \%$ of the total population (Figure 3.3).

In addition, Vietnam's poverty rate has declined in recent decades, falling from $70 \%$ of the population in the mid-1980s to $58 \%$ in $1993,37 \%$ in 1998 and $29 \%$ in 2002 . The current GDP per capita is USD1240 and the household poverty rate stood at $12.3 \%$ of the population in 2009 (Forsberg 2011, Markussen and Tarp 2011).

Vietnam has integrated its economy into the international economy, gradually creating a secure legal environment for business, including by joining ASEAN and the ASEAN Free Trade Area (AFTA) in 1995, the Greater Mekong Subregion (GMS) Economic Cooperation Program in 1992, the Asia-Pacific Economic Cooperation (APEC) in 1998 and the World Trade Organization (WTO) in 2007. In addition, the government has made significant progress in liberalising foreign trade and promoting foreign direct investment (FDI). The impact of these reforms has been significant. For example, the total value of the country's exports increased by more than $16 \%$ a year during 2000 2009 (CIEM 2010, GSO 2010).

Despite these remarkable achievements, some authors have warned that the political regime - which has continued as a control system rather than one based on efficiency and service delivery - will encounter several challenges (Nguyen and Kammeier 2002, Forsberg 2011).
The dominant role of the government in all sectors and decision-making processes inhibits incentives for sectoral reform. Furthermore, civil organisations have limited accountability. In addition, the understanding of marketisation in Vietnam differs from the usual; that is, it refers to privatisation under state control with public investment resources, state budget, soft credit and development funds extracted to maintain and develop giant state corporations (Forsberg 2011). The border between public and private ownership of public resources and market access is blurred. As a result, state budget and public resources are being used unproductively, and state investment in social development has been limited (MOLISA 2010). Moreover, an uncertain regulatory environment, due mainly to different interpretations of regulations by local administrations and subsections of the bureaucracy, discourages foreign direct investment (FDI), which is a problem because Vietnam is a capital-scarce country (Dixon 2000). Despite aggregate economic growth and improvements in average income, rural populations and low-income earners still have limited access to basic social services and are further disadvantaged by the unequal distribution of growth and development funds among regions and social groups (Forsberg 2011).

Some scholars have claimed that policymakers actually viewed Doi Moi as a way to improve the socialist model, not to abandon it (Dutt $e t$ al. 2004). As institutional changes take a long time (Swallow et al. 2007), Doi Moi and subsequent reforms should be seen as a long-term process as the government finds a balance between a market economy and a socialist political system.

A particularly slow aspect of reform is persuading all segments within society to support the reform effort. In particular, SOEs that operate inefficiently and at a financial loss, thus having a great negative impact on the economy as a whole, need to be abolished; the government cannot afford to continue subsidising these industries, making structural changes critical (Doan et al. 2005).

According to most of our key informants, the important questions concern not whether the political regime should be changed, but how to increase the effectiveness of the state machinery, how to train people to work in the new conditions, 

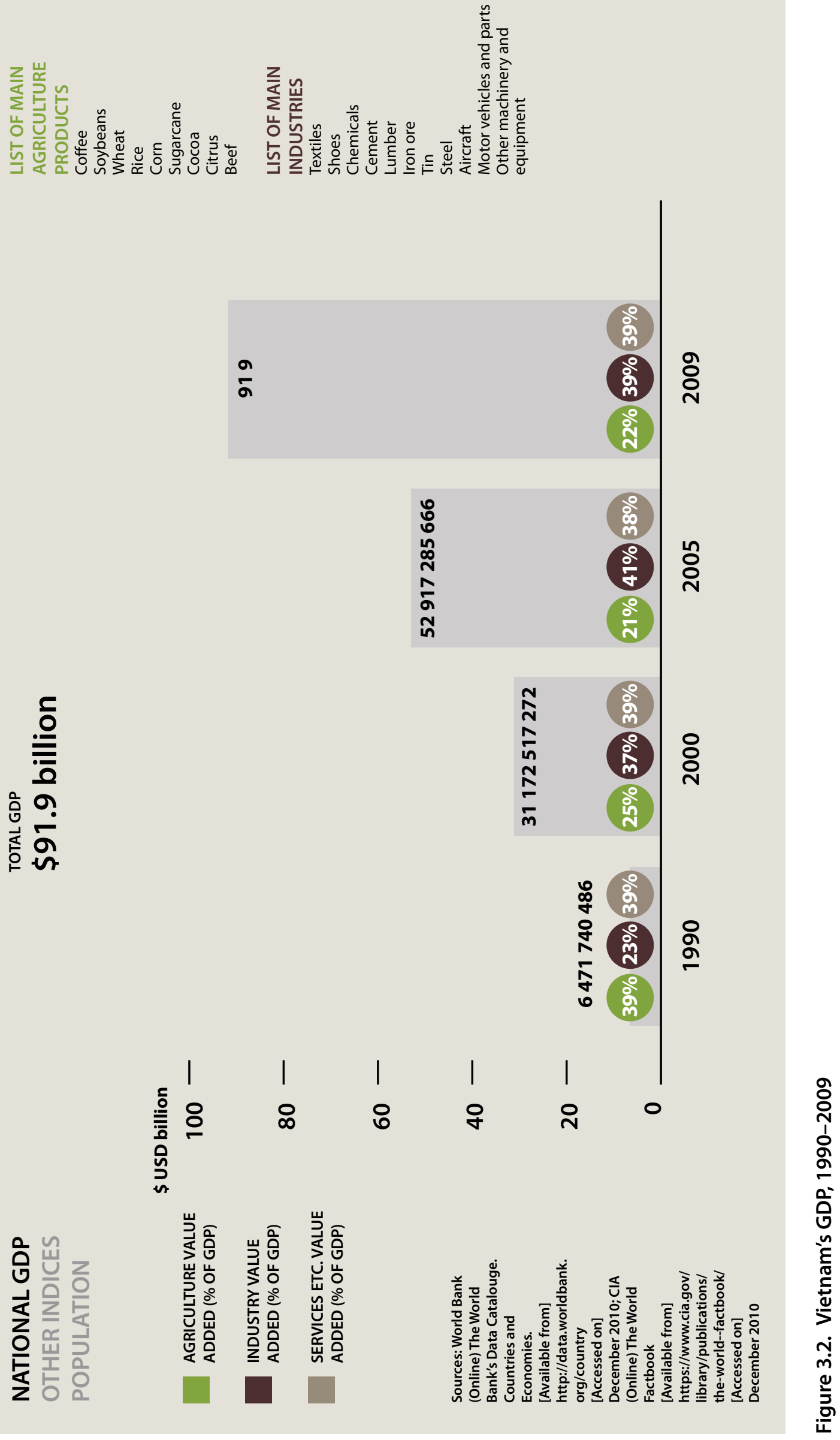

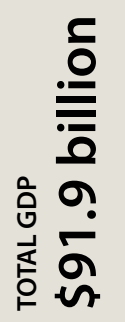



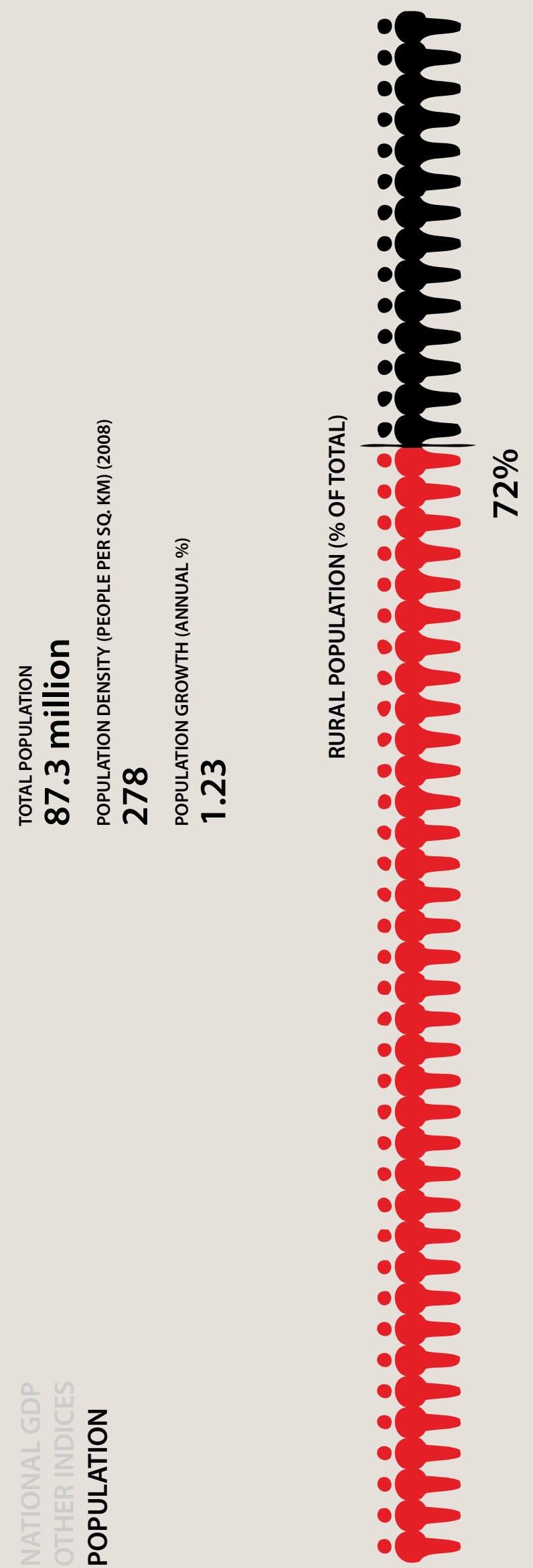
and what are the objectives, the methods and the extent of state intervention. Of course, in addressing such issues, it is important not to overlook the fact that if the current institutional framework does not evolve in step with economic development, Vietnam may not have a juridical framework capable of mediating economic, social and political disputes, which could ultimately lead to socio-political instability (Quan 2003, Dutt et al. 2004).

\subsection{Decision-making processes and operation of government organisations}

Policymaking in Vietnam is a 'multi-level, multi-player' process involving central agencies, line ministries, provinces, communities and the Communist Party. Formulating implementable policies requires building consensus for policy change at all these levels and institutions. This takes time, resources, negotiations and bargaining, and requires a sufficient period before stabilising (Abonyi 2002, Pham et al. 2008). Consequently, efforts to reduce deforestation and forest degradation and to design a REDD+ mechanism must involve a range of factors and relationships beyond the scope of the forestry sector and REDD+ itself, if the resulting conditions are to be feasible. Given this environment, a modest beginning (e.g. pilot projects) appears to be the most appropriate.

For REDD+ to be successful, related organisations must be effective and efficient. At the macro level, the MPI coordinates and allocates the budget and prepares sectoral plans for the nation. MoFi establishes financial norms related to any transactions. Technical ministries (e.g. MARD and MONRE) provide technical guidelines for each sector but come under the supervision of MPI and MoFi (Figure 3.4.).

The fact that many environmental programmes are governed under a multitude of different ministries and agencies leads to overlapping objectives and project components, as well as cost ineffectiveness, including increased transaction costs, makes it difficult for local authorities to coordinate the programmes (Pham et al. 2008).

The complexity of the horizontal and vertical connections in the administrative system creates
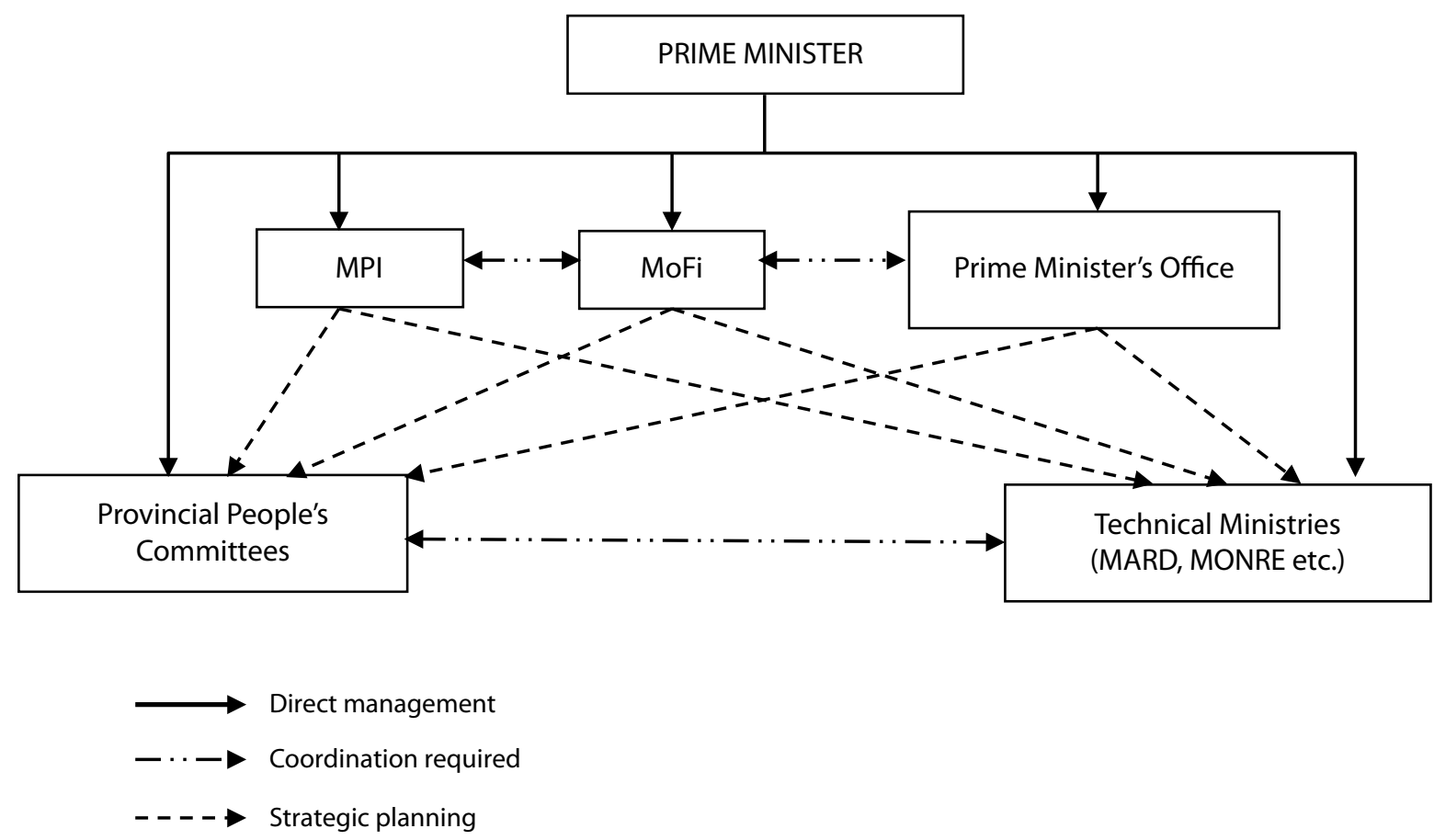

Figure 3.4. Government planning system for environmental activities in Vietnam 
many obstacles for environmental issues in general and REDD+ in particular. MONRE and MARD perform only technical functions, while $\mathrm{MoFi}$ and the MPI set the strategic directions through budget allocations. Top-down planning means that programmes are selected on the basis of how much funding is available rather than on technical priorities (Pham et al. 2008). Moreover, development continues to be defined simplistically as economic growth with a focus on heavy economic infrastructure (Forsberg 2011). The system restricts implementing agencies' independence and commitment when planning their own work. Moreover, because the MPI's priorities change from year to year, it is difficult for government agencies and the private sector to secure a long-term commitment to finance REDD+.

At the central level, policy must receive unanimous support; however, decision-making remains opaque to the public and institutional capacity for policy implementation and legal enforcement is lacking. The close ties between the bureaucracy and state corporate groups means decision-making is vulnerable to influence from vested interests and the public sector responds primarily to the needs of vested interests (Forsberg 2007, Vu 2009). A major concern, therefore, is how to sustain resources in the state budget so as to ensure that the necessary resources are available for state industrialisation priorities while state financial responsibility for social services is transferred to households (Forsberg 2011).

At the local level, Vietnam has three administrative tiers: province, district and commune levels. The local government at each level is headed by 'People's Committees' (PCs). Local government plays a crucial role in determining security over property rights. Most obviously, the state manages the issuance of Land Use Right Certificates (LURCs). While the process of issuing LURCs to millions of land users progressed with impressive speed and without obvious signs of widespread abuse by local authorities in the 1990s (Do and Iyer 2008), the process is now widely perceived as seriously compromised by corruption (World Bank 2009, Markussen and Tarp 2011).

Local governments also control all formal lending institutions operating in rural areas by screening applicants for loans from the most important state banks (e.g. Vietnam Social Policy Bank, which extends non-collateralised loans to poorer families, and the Vietnam Bank for Agriculture and Rural Development, which lends to rural households with security in LURCs (Markussen and Tarp 2011).

Local government leaders in Vietnam have generally been accountable more to higher levels of government than to local populations. Although Markussen and Tarp (2011) claimed that downward accountability has been strengthened in recent years through the adoption of the 'Ordinance on Grassroots Democracy', Fritzen (2006) found that improvements in local empowerment in Vietnam have been marginal, and suggested that effective local institutions have not yet emerged. Moreover, some local officials are not interested in being 'decentralised' because they are afraid of losing government subsidies and regular funding (Pham et al. 2008). This finding is similar to Leonard's (2004) argument that decentralisation does not always lead to greater governmental efficiency as the type of politics that prevails is a key determinant of efficiency.

\subsection{National strategy for socio- economic development}

The Vietnamese government has recently drafted the Socio-Economic Development Strategy (SEDS) for 2011-2020, which is one of the central documents in setting the national development pathway in the next 10 years. This document is built upon the previous National Strategy for Socio-Economic Development for 2001-2010, and aims to bring the country out of underdevelopment and to lay the foundations to be fully industrialised by 2020. To this end the strategy focusses on human resource development through enhancement of the scientific and technological capacities. Other priorities include the further development of the socialist-oriented market economy through establishment of basic institutions and safeguards for smooth and efficient operation. The strategy also mentions infrastructure construction and strenghtening defence and security.

The previous strategy (2001-2010) put great emphasis on ensuring that infrastructure would 
be able to meet the demands of socio-economic development, national defence and security. The Socio-Economic Development Plan (SEDP) for 2005-2010 envisaged Vietnam as 'an industrialised country by 2020', with aims to change its status from that of low-income country and increase GDP per capita (about USD 622 in 2005) to USD 1050 - USD 1100 by 2010 .

Moreover, the 2005-2010 SEDP aimed to enhance the leading role of the state economic sector, so that it would govern key economic domains, with state enterprises to be renewed and developed in order to promote efficiency in production and commerce. Furthermore, the strategy envisaged the 'vigorous and sustainable' development of the collective economic sector, the individual and small-owner economic sector, the private capitalist economic sector, the state capitalist economic sector and the foreign investment economic sector.

In the current strategy for 2011-2020, the government highlights the importance of stable macroeconomic management and a stable political climate. The clear 'sustainability' focus of the strategy reflects the government's growing recognition that economic growth at any cost is no longer viable. In particular, as Vietnam has been recognised as highly vulnerable to climate change, the strategy acknowledges that it is crucial to mainstream climate change into the country's planning processes. The strategy encourages the private sector to develop supporting industries and grants it protection from red tape and unfair competition by state enterprises; although the state enterprises will continue to play an important role in the economy, they will be subject to market discipline. Priorities in the government's draft strategy are to promote poverty reduction and a socialist democracy as drivers to achieve rapid and sustainable development, to improve teaching in universities and vocational schools, and to mobilise a systematic attack on corruption without compromising the nation's environmental integrity.

\subsubsection{Hydropower development}

In Chapter 1, we mentioned that hydropower plant development is a major driver of deforestation and forest degradation. In this section, we revisit this issue and provide some background. As economic development is progressing rapidly, the country needs to address its increasing demand for energy. Vietnam's Electricity Law, which came into effect on 1 July 2005 , is the first law to govern activity in the country's electricity sector. The Electricity Law was passed in accordance with Vietnam's Strategy for Electricity Development, which set ambitious targets for electricity output up to the year 2020 . The law aims to stimulate development and diversify forms of investment in the electricity sector. However, the highest priority is accorded to developing hydropower resources rather than thermal power, gas, nuclear energy, electricity imports or alternative energy (Nguyen 2008).

In the electricity and energy security decisionmaking process, Vietnam Electricity (EVN) under the Ministry of Industry plays a dominant role. According to interviewees, there was limited consultation prior to the adoption of the national strategy, which meant no opportunity for participation for other actors (e.g. civil society, NGOs, research community, domestic media), which might have advocated for a more environmentally friendly approach to energy security. The potential environmental impacts of major hydropower projects are usually assessed and reviewed by specialised agencies such as those under the Ministry of Natural Resources and Environment (MONRE) only during the feasibility assessment stage (Nguyen 2008). Sustainable development requires tradeoffs between economic infrastructure and environmental protection, between food security and energy security, and between multilateral cooperation and national sovereignty (Nguyen 2008). However, because of the national priority on economic development, such trade-offs are not given serious consideration in the politics and power relations of the decision-making process with regard to the construction of hydropower dams. More importantly, the beneficiaries of hydropower projects, including corporations, industries and more generally urban residents, are usually much more politically and economically powerful than those adversely affected by hydropower projects, many of whom are poor ethnic minorities in rural areas (Nguyen 2008). 
Table 3.1. Plantation and export of coffee and rubber in Vietnam, 1995-2009

\begin{tabular}{lrrrrr}
\hline & 1995 & 2000 & 2005 & 2008 & 2009 \\
\hline Coffee (ha) & 186400 & 561900 & 497400 & 530900 & 537000 \\
Coffee export (tonnes) & 248100 & 733900 & 912700 & 1061000 & 1183500 \\
Rubber (ha) & 278400 & 412000 & 482700 & 631500 & 674200 \\
Rubber export (tonnes) & 138100 & 273400 & 554100 & 659000 & 731400 \\
\hline
\end{tabular}

Source: General Statistics Office (2009)

In sum, rapid economic growth continues to be a higher priority than environmental protection. Underlying national strategies is the sense that a classic political question facing powerful groups when and how particular interests should suffer to preserve the overall game - has been increasingly hard for the Vietnamese polity to address (Fforde 2008).

\subsubsection{Coffee and rubber development}

Reforms in the agriculture sector contributed greatly to the increase in exports, with Vietnam becoming one of the world's leading exporters of rice, coffee, rubber and black pepper. Rubber ranks third among Vietnam's agricultural exports in terms of value, accounting for $2.9 \%$ of the total value of exports (Nguyen et al. 2008). The rubber industry exhibits long-term potential for growth and is likely to attract further investment. To sustain its position in the international market, Vietnam needs to produce high-yield rubber seedlings, capable of tolerating changeable climate conditions; apply advances in farming technologies; reduce production costs; and increase economic efficiency. At the same time, it needs to develop the less economically productive regions such as the Central Highlands and the Northwest. For this it also needs improved infrastructure, including transportation networks and irrigation schemes, although this entails reducing forest areas to make way for plantations and infrastructure.

From 1995 to 2009, the area of rubber plantations grew at an average of $7 \%$ a year. During the same period, the amount of rubber exported increased 500\% (Table 3.1). With Decision No. 750/QDTTg, dated 3 June 2009, the government set the target of stabilising the total area of rubber at 800000 ha by 2020 . Achieving this target will require the planting of an additional $220000 \mathrm{ha}$, requiring the conversion of 308000 ha $^{9}$ of forest land, poor-quality farmland or unused land that is appropriate for rubber trees.

Since 1995, Vietnam has become a well-known coffee exporter. For some years, coffee exports generated big profits for producers, as global prices were high. This encouraged producers to rapidly plant more coffee; as a result, from 1995 to 2009, the area of coffee plantations increased by nearly $300 \%$, while the export volume increased by nearly $500 \%$ (Table 3.1). In 2009, Vietnam exported coffee to 88 nations and ranked as the second largest exporter in the world.

These leading sectors in the economy continue to put great pressure on forest land. The policy of trade liberalisation created greater incentives for foreign and domestic companies to expand their operations inside and outside the country, including in fields related to forest products. The government recognises the need to boost the economic contribution and efficiency of the forestry sector, which is currently seen to be underperforming in economic terms (Doan et al. 2005). However, joining AFTA and the WTO exposed the country to fierce international competition in the forest products trade. To improve competitiveness, the government worked hard to liberalise trade regulations. However, becoming competitive has been particularly difficult in the timber-processing sector, which depends mainly on imported sources. To reduce costs and increase profits, firms seek locally

9 It is calculated that planting 1 ha of rubber trees requires clearing 1.4 ha of natural forest, because roads need to be built to $\log$ the forest. 
- sourced timber - which naturally leads to deforestation.

\subsubsection{Wood-processing industry}

Timber and forest products have experienced rapid growth in terms of value, which demonstrates the sector's great contribution to the national economy. Vietnam is the fourth largest exporter of wood products and its timber industry furniture manufacturing in particular - is the fifth largest foreign exchange-earning sector in the country (ProForest 2009). The export value of this industry increased on average by $28 \%$ a year during 2001-2009 (GSO 2009, CIEM 2010). In 2008, for example, Vietnam exported furniture to 120 countries, with a total value of USD 2.8 billion (Forest Trends 2010). Vietnam also exports about 2 million tonnes of woodchips with a value of about USD 3.5 billion (Paper Index Times 2009). The forest-processing industry grew by $400 \%$ between 2005 and 2009 . The three main destinations for Vietnam's wood-product exports are the USA, the EU and Japan, which together account for nearly $80 \%$ of the sector's total export value (Table 3.2).

Vietnam is one of the most important suppliers of wood products for the European market. Because of a tariff-free policy, this market is very attractive for wood products from Asia. The export value of Vietnam's wood products to the EU has seen large increases, with an annual growth rate in value of 26\% during 2006-2008.

While the export value of timber products from Vietnam to US, EU and Japan increased from 2006-2008, this figure reduced slightly in 2009. This decline is explained by numerous reasons. First, the country is negatively affected by the global financial crisis and only started to recover since the end of 2009 (Nguyen and Dinh 2011). In fact, the country has witnessed a sign of reduction in timber production since the end of 2008 due to global financial crisis (Pham and Nguyen 2009). Second, although exports declined, Vietnam still had to import 70-80\% of its raw material at higher prices (Vietnam Customs Department 2010). At the same time transportation and oil prices increased. As a result, Vietnam lost its competitive advantage in marketing its timber products ( $\mathrm{Vu}$ 2011).
Thirdly, while Nguyen and Tran (2011) argued that recent amendments to the Lacey Act (2008) and the EU Timber Regulation (2010) requiring timber operators to establish a "due diligence" system which will minimise the risk of handling illegal timber had substantial impact on the wood processing industry in Vietnam, several interviewees disagreed that the decline of timber exports to the US and the EU in 2009 was because of these regulations as they only started to see their impact in 2010. According to these interviewees, the decline was mainly due to the global financial crisis only.

The national economy has experienced a consistently high growth rate of $7 \%$ a year during recent years. This figure is forecast to increase, rather than decline, over time (de Jong et al. 2006). According to the National Forest Strategy for 2006-2020, the country aims to become fully industrialised by 2020, with increasing demand for timber and NTFPs (Table 3.3).

The significant contribution of the woodprocessing industry to the national economy and future growth in demand for timber mean that ensuring sufficient raw materials for this competitive sector has become a government priority. The timber industry currently depends on imports for $80 \%$ of its timber supply because of prohibitions on logging and the low quality and productivity of existing plantations (Doan $\mathrm{et} \mathrm{al}$. 2005, GSO 2009, Forest Trends 2010). In 2008, the roundwood equivalent volume (RWE) of imported plantation wood was four times greater than the amount supplied to the timber sector from plantations in Vietnam (ProForest 2009). Domestic production during 2001-2009 increased by only $5.9 \%$, whereas imports increased by $18 \%$ in the same period (see Table 3.4).

To address the problem, the Vietnam Forestry Development Strategy 2006-2020 aims to reduce dependence on international imported timbers (from $80 \%$ to $20 \%$ ) by 2020 by expanding the area of plantations, developing domestic forest reserves to replace imports, certifying $30 \%$ of national production forests and developing and upgrading the export processing industry. However, as ProForest (2009) noted, this goal is ambitious for several reasons. First, maintaining 
Table 3.2. Export value of timber products from Vietnam to major markets, 2006-2009

\begin{tabular}{lcccccc}
\hline \multirow{2}{*}{ Market } & \multicolumn{2}{c}{2006} & \multicolumn{2}{c}{2008} & \multicolumn{2}{c}{2009} \\
\cline { 2 - 7 } & $\begin{array}{c}\text { Value } \\
\text { (USD million) }\end{array}$ & $\begin{array}{c}\text { Share } \\
(\%)\end{array}$ & $\begin{array}{c}\text { Value } \\
\text { (USD million) }\end{array}$ & $\begin{array}{c}\text { Share } \\
(\%)\end{array}$ & $\begin{array}{c}\text { Value } \\
\text { (USD million) }\end{array}$ & $\begin{array}{c}\text { Share } \\
(\%)\end{array}$ \\
\hline EU & 500 & 26.32 & 792 & 28.00 & 419 & 20.72 \\
Japan & 268 & 15.05 & 372 & 13.14 & 293 & 14.50 \\
USA & 745 & 39.22 & 1049 & 36.30 & 874 & 43.28 \\
Others & 364.3 & 19.4 & 445.5 & 22.50 & 434.3 & 21.50 \\
\hline
\end{tabular}

Source: TCTK, imports and exports 2006-2009, www.vietfores.org

Table 3.3. Forecasts for industrial consumption of Vietnam's timber products

\begin{tabular}{|c|c|c|c|c|c|}
\hline \multicolumn{6}{|c|}{ Forecasts for consumption of Vietnam's sawn log and wood-based panelling $\left(1000 \mathrm{~m}^{3}\right)$} \\
\hline Product & 2003 & 2010 & 2015 & 2020 & Annual growth (\%) \\
\hline Sawn logs & 2211.0 & 3589.9 & 5009.5 & 6991.5 & 7 \\
\hline MDF & 40.1 & 79.6 & 117.4 & 164.4 & $7-8$ \\
\hline Particle board & 80.1 & 147.6 & 215.5 & 312.5 & $8-9$ \\
\hline $\begin{array}{l}\text { Wood-based } \\
\text { panelling }\end{array}$ & 11.0 & 18.3 & 26.1 & 37.2 & $7-9$ \\
\hline \multicolumn{6}{|c|}{ Forecasts for consumption of Vietnam's paper (1000 tonnes) } \\
\hline Product & 2003 & 2010 & 2015 & 2020 & Annual growth (\%) \\
\hline Newspaper & 54.8 & 92.8 & 133.4 & 192.0 & $8-9$ \\
\hline Writing paper & 159.9 & 295.2 & 451.0 & 690.6 & $9-11$ \\
\hline Cardboard & 680.1 & 1240.9 & 1880.9 & 2856.4 & $9-11$ \\
\hline Others & 75.8 & 138.3 & 209.6 & 318.4 & $9-11$ \\
\hline Total & 970.6 & 1767.2 & 2647.9 & 4057.4 & $9-11$ \\
\hline \multicolumn{6}{|c|}{ Forecasts for demand for Vietnam's timber and forest products } \\
\hline & & 2003 & 2010 & 2015 & 2020 \\
\hline $\begin{array}{l}\text { Timber: domes } \\
\text { and export (10 }\end{array}$ & nsumption & 7420 & 14004 & 18620 & 22160 \\
\hline $\begin{array}{l}\text { Large timber } \\
\text { industries }\end{array}$ & rindustrial & 4561 & 8030 & 10266 & 11993 \\
\hline $\begin{array}{l}\text { Small wood us } \\
\text { particle board } \\
\text { panelling }\end{array}$ & $\begin{array}{l}\text { producing } \\
\text { ood-based }\end{array}$ & 1649 & 2464 & 2992 & 1682 \\
\hline Pulpwood & & 1150 & 3388 & 5272 & 8283 \\
\hline Pitwood & & 60 & 120 & 160 & 200 \\
\hline $\begin{array}{l}\text { Total export v } \\
\text { products and }\end{array}$ & $\begin{array}{l}\text { f timber } \\
\text { (million USD) }\end{array}$ & 721 & 2400 & 3200 & 4000 \\
\hline Timber produc & & 567 & 2100 & 2600 & 3200 \\
\hline NTFPs & & 154 & 300 & 600 & 800 \\
\hline
\end{tabular}

Source: MARD (2006) 
Table 3.4. Production and export value of forest products from Vietnam, 2001-2009

\begin{tabular}{|c|c|c|c|c|c|c|c|}
\hline & 2001 & 2005 & 2006 & 2007 & 2008 & 2009 & $\begin{array}{c}\text { Average } \\
\text { increase } \\
(\%)\end{array}$ \\
\hline $\begin{array}{l}\text { Logging volume } \\
\left(1000 \mathrm{~m}^{3}\right)\end{array}$ & 2397 & 2996 & 3129 & 3462 & 3562 & 3767 & 6.0 \\
\hline $\begin{array}{l}\text { Forest } \\
\text { production value } \\
\text { (USD million) }\end{array}$ & 540.17 & 644.83 & 751.60 & 868.00 & 880.14 & 540.17 & 5.9 \\
\hline $\begin{array}{l}\text { Export value } \\
\text { of timber and } \\
\text { timber products } \\
\text { (USD million) }\end{array}$ & 344 & 1561 & 1943 & 2385 & 2829 & 2550 & 28.0 \\
\hline $\begin{array}{l}\text { Import value } \\
\text { of timber and } \\
\text { timber products } \\
\text { (USD million) }\end{array}$ & 234 & 640 & 760 & 1022 & 1010 & 888 & 18.0 \\
\hline
\end{tabular}

Source: General Statistics Office 2009

and/or expanding plantation areas requires stability in land use planning. Yet, as pointed out in Chapter 1, (unplanned) conversion of land to other purposes (e.g. agricultural expansion and infrastructure development) threatens to undermine this plan. Second, the domestic woodprocessing industry is constrained by the highly competitive woodchip sector, the high cost of transportation between plantations and factories, bureaucracy and the poor quality, fragmentation and local unpopularity of much of the current plantations (Lang 2002, de Jong et al. 2006, ProForest 2009). Third, as Markopoulos (2009) pointed out, linkages and cooperation between enterprises are limited and supportive credit and investment policies are lacking; furthermore, domestic production means a high level of dependence on imported wood and accessories and there is increasing demand for legality or sustainability assurances in the main export markets. Fourth, plantations produce only smalldiameter logs, which are mostly consumed by the woodchip industry (ProForest 2009), whereas the furniture sector requires large-diameter timber. As a result, Vietnam is likely to remain dependent on imports from other countries, entailing a high risk of sourcing products from unknown and possibly illegal sources in countries such as Lao PDR and Cambodia (GSO 2009, ProForest 2009, Forest Trends 2010).
Forest plantations are generally not perceived as a viable business, mainly because there is limited understanding about timber and forest products and how to generate revenue and benefits from forest plantations. In addition, the oversupply of timber to the pulp and paper industries has led to low prices (Le 1998, To and Vu 2000). Currently, forestry agencies and private enterprises are the only stakeholders investing in forest plantations (Do 1998).

Furthermore, a large number of intermediaries involved in timber trading can pose high transaction costs and smallholders are forced to accept low prices; income therefore becomes negligible, making it impossible to accumulate sufficient capital to continue reforestation (Ngo 1996,Pham et al. 2010). ProForest (2009) also emphasised that the government must acknowledge that the growth in exports was attributable to factors that no longer have much impact, namely incentives that promoted trade with the USA, as well as a shift in the USA's supply of wooden bedroom furniture from China to Vietnam in response to the imposition of anti-dumping duties by the USA during 2000 and 2007. At the same time, competition with manufacturers in other (particularly East Asian) countries is likely to intensify in the markets to which Vietnam exports wooden furniture. 
This reduces the opportunities for Vietnam to increase its share in the current market and might have significant implications for the woodprocessing sector.

With the decline in logging due to the disappearance of old-growth forests and recent government restrictions, some people have turned their attention to NTFPs because of the high demand for cross-border trade with China and the possible increase in incomes for those collecting and selling these products (Sunderlin and Huynh 2005). However, this trend has led to overexploitation and restricted supply (McElwee 2001). Merckx (2011) claims that good governance is crucial to maintaining existing forests and reducing forest degradation and loss and that it is necessary to avoid rapid land use change, illegal logging and consumption of cheap illegal timber, as these undermine efforts to improve forest practices and governance.

At the same, demand for assurance about the legality of timber is growing in many of the markets to which Vietnamese products are exported, as shown by the Lacey Act in the USA and the EU FLEGT Action Plan, as well as a range of private and public sector purchasing policies related to the verification of the legality of timber sources (ProForest 2009). In 2009, Vietnam had only one Forest Stewardship Council (FSC)certified (plantation) forest of 9904 ha but about 170 FSC chain-of-custody certificates. This small total area is mainly due to the scarcity and high cost of imported certified timber (Markopoulos 2009). Vietnam is at present negotiating with the EU on VPAs (Voluntary Partnership Agreements) under the EU FLEGT Action Plan. Vietnam is in a slightly different position from other countries that have signed VPAs in that it is a processing country, rather than a producing country.

The number of enterprises in the wood-processing industry grew by $23.5 \%$ a year in $2005-2007$, and the industry was a major employer of women and rural labour (Markopoulos 2009). However, the wood-processing sector is labour intensive and has been classified as high risk in terms of violations of labour laws (Global Compact and VCCI 2010); although sectors such as garment and shoe manufacturing have been subject to intensive case studies and research attention, this aspect has been underestimated and overlooked in the forestry sector.

In the past, FDI and domestic private sector investment in the plantation economy have been limited. However, this may change with the new Law on Forest Protection and Development, which provides a more conducive environment for leasing of production forests to forest farmers, domestic economic organisations, overseas Vietnamese and foreign economic organisations, as part of the strategy to supply raw materials to the pulp and timber industries and reduce the pressure on natural forest. Wood processing is an attractive FDI target, and has advantages with respect to technology transfer and research and development. FDI capital provides additional resources for growth, boosts employment of labourers, enables technology transfer, helps to enhance technical and management capacity, and enhances the efficiency, productivity and quality of goods and services. However, it is recognised that Vietnam's market economy has not yet developed to the extent where it has a buoyant market for science and technology.

FDI remains relatively low in the agricultural sector in Vietnam, particularly in forestry (Doan et al. 2005), and the potential for future development of the plantation economy is uncertain for several reasons; that is, development potential is often site-specific and linked to those areas with good existing infrastructure, including access to processing facilities (Doan et al. 2005). Little information on the impact of FDI in forest management in Vietnam is available. 


\section{The REDD+ policy environment}

$\mathrm{T}$ This chapter discusses the processes behind the formation of the REDD+ policy in Vietnam. Because of the influence of international agreements and conventions on policymaking in Vietnam, as mentioned in Chapter 2, the first section presents some of these agreements and describes Vietnam's engagement in them. The subsequent sections examine REDD+related policy processes and the actors involved.

\subsection{Global policies related to climate change}

Vietnam has shown great commitment to mitigating climate change, as demonstrated through its participation in international initiatives. The country is a signatory to the UNFCCC (1994) and the Kyoto Protocol (2002). Vietnam also meets all three requirements for participation in the Clean Development Mechanism (CDM): (1) voluntary participation in the CDM; (2) designation of a national agency for CDM; and (3) approval of the Kyoto Protocol. Vietnam is now implementing energyand forestry-related CDM projects. This section describes Vietnam's involvement in CDM and other international initiatives.

\subsubsection{AR-CDM projects and stakeholders}

As the Designated National Authority (DNA) for the CDM, MONRE coordinates the implementation of CDM activities. The CDM National Executive and Consultative Board (CNECB) advises and directs the DNA in managing and evaluating CDM projects.
The CNECB is chaired by the Director of International Cooperation within MONRE and has 14 members, including representatives of nine ministries.

Vietnam offers incentives for enterprises involved in CDM projects, as provided by Decision 130/2007/QĐ-TTg, including reduced tax; low land use levies or land rent; fixed assets depreciation; state investment credit; price subsidies on products from CDM projects in priority domains; and financial support in formulating projects. This decision also states that Certified Emission Reductions (CERs) are owned by investors who invest in and implement CDM projects, which are administered by the Vietnam Environmental Protection Fund.

According to the Energy and Environment Consultancy Joint Stock Company (2010), Vietnam is currently ranked eighth in the world in terms of the number of CDM projects registered. The government recognises the possible role of the nation in facilitating the world's transition to a lower-carbon development pathway and emphasises its commitment towards a green economy in numerous legal documents such as the National Target Program on Climate Change Mitigation and Adaptation, the National Climate Change Strategy and National SocioEconomic Development Plan. However, most of the CDM projects are hydropower projects (accounting for $74.7 \%$ of total projects registered for Vietnam). According to informants from MONRE, among the 49 project designs approved in 2010, only one is an afforestation-reforestation 
(AR-CDM) pilot project registered with UNFCCC and managed by the Forest Protection and Development Fund. Other projects are managed by private companies or corporations, and two are managed by provincial departments of resources and environment in collaboration with private companies (MARD expert, personal communication).

Pham et al. (2008) offered several reasons for the shortage of AR-CDM projects. First, the transaction costs are high, because of the technical requirements for establishing and monitoring the process; in addition, commitment among local people is low, because of their limited understanding of the DNA and the absence of upfront payments by either buyers or donors. Second, no effective, efficient and equitable benefit-sharing mechanism is in place in Vietnam in relation to AR-CDM to ensure the sustainability of the projects. Third, the project is not having a pro-poor impact because of inequitable land use allocation (Pham et al. 2008, 2009). These points are consistent with the Energy and Environment Consultancy Joint Stock Company (2010) study, which cites technology, finance and limited capacity as three major obstacles for CDM in Vietnam.

\subsubsection{Participation in international initiatives}

Vietnam is an active participant in several international REDD+-related initiatives, including the World Bank's Forest Carbon Partnership Facility (FCPF) and the United Nations Collaborative Programme on Reducing Emissions from Deforestation and Forest Degradation in Developing Countries (UN-REDD). Vietnam began participating in Phase 1 of UN-REDD in August 2009, with the aim of building capacity at both central and local levels and accelerating regional collaboration in preparation for REDD+. This phase received grants totalling USD 4.32 million. UN-REDD planned to submit the proposal for Phase 2 to the donor for approval before the end of 2011. The country has also received special bilateral technical assistance from the governments of Australia, Germany, Finland, Japan and the USA, and from the International Union for the Conservation of Nature (IUCN), the World Agroforestry Centre (ICRAF), Winrock
International and the Netherlands Development Organisation (SNV).

Vietnam's participation in the FCPF involves submission of a Readiness Plan Idea Note (R-PIN) followed by the development of a more advanced Readiness Preparation Proposal (R-PP), which documents progress in the development of a national REDD+ strategy. Vietnam was among the first countries to gain approval for its R-PIN in July 2008; the R-PP was submitted in October 2010 and is currently under review. Vietnam's plan has been praised for the high level of national ownership and for the links drawn to its extensive experience with PES schemes (UN-REDD 2009, World Bank 2011).

\subsection{REDD+ policy actors, events and processes in Vietnam}

\subsubsection{The REDD+ national policy environment}

On 5 December 2011, the government approved Decision No. 2139 on the National Climate Change Strategy, which is the first overarching document to make a cross-sectoral and comprehensive assessment of Vietnam's response to climate change. This strategy also acknowledges the role of REDD + in climate change mitigation and sustainable forest management and demonstrates the government's strong political commitment to REDD+. The government requires that all sectoral strategies, including the National REDD+ Programme, be based on and aligned with this overarching document. This means that previous documents, such as the Action Plan Framework for Adaptation and Mitigation of Climate Change in the Agriculture and Rural Development Sectors 2008-2020 created by MARD (Decision No. 2730/QĐ-BNN-KHCN, 5 September 2008), need to be revised.

At the time of writing, Vietnam was drafting the National REDD+ Policy (NRP) for 2011-2020, with plans to have it submitted and approved in early 2012. The plan identifies two main periods. During 2011-2015, the focus will be on capacity building and institutional development for relevant organisations and individuals at central and local levels (about 40 provinces with natural forest area over $25000 \mathrm{ha}$ ) as well as 
pilot REDD+ activities in pilot provinces. Actual implementation will take place during 20162020. At national level, payments will be made for reducing emissions, enhancing forest carbon stock, conserving the carbon pool and practising sustainable management of forest resources on a national scale with proper measurement. It is expected that by 2020 , livelihoods of local people implementing REDD+ will have been improved.

Vietnam's major policies related to climate change in general and REDD+ in particular are presented in Figure 4.1.

The Vietnamese government introduced the National Target Programme (NTP) (Decision 158/2008/QĐ-TTg, 2 December 2008) to evaluate the potential impact of climate change, to develop feasible mitigation action plans and to ensure sustainable development of the country, developing towards a low-carbon economy and participating in international efforts to mitigate climate change. To facilitate the implementation of the NTP, the government established the National Executive Board, Programme Chairing Committee and Programme Office, with the involvement of government departments and related agencies (including MARD, the Ministry of Planning and Investment, ministries and ministry-level government agencies), PPCs, CSOs, NGOs and enterprises. The NTP sets out key tasks and measures for climate change mitigation up to the year 2015. Although the NTP does not include emission reduction targets in its measures, MONRE is calculating specific targets.

\subsubsection{Government agencies responsible for REDD+}

Institutional arrangement for REDD+ implementation is presented in Figure 4.2.

To ensure coordination between MONRE and MARD in implementing climate change and the REDD+ programme, the Prime Minister of Vietnam issued guideline No. 282/VPCOQHQT (13 January 2011) setting out the division of responsibilities between the two ministries and their individual and joint duties in implementing REDD+ and strategies. This decision stated that MARD would take the lead in developing the National REDD+ Programme, strengthen institutional and organisational capacities, establish a National REDD+ Steering Committee, secure support from the international community and strengthen collaboration among line ministries, economic sectors and local authorities. MONRE was assigned to take the lead in preparing a proposal for establishment of an intersectoral climate change negotiation delegation, in close collaboration with MARD and related agencies, to be submitted to the Prime Minister for consideration and approval. MONRE, in collaboration with other ministries, is also responsible for developing a proposal on National Appropriate Mitigation Actions (NAMA) for Vietnam to request international support, providing line ministries, the economic sector and local authorities with guidance in designing an appropriate roadmap to integrate low carbon emission development activities into socio-economic development strategies and plans, starting from 2011; selecting sectors, programmes and projects that have potential for low-carbon development consistent with UNFCCC provisions and the Kyoto Protocol with the aim of gaining support from multiand bilateral development partners; and developing appropriate mechanisms and incentive policies to encourage the transfer and application of advanced, environmentally friendly and low carbon emission technologies across sectors and fields.

The government, with Decision 39/QD-BNNTCCB (7 January 2011), also established a National REDD+ Steering Committee to implement REDD+ in Vietnam, chaired by the Minister of MARD with members coming from the MPI, MoFi and MONRE, among others. From MARD, VNFOREST acts as the focal point and the Director of Science, Technology and International Cooperation serves as director of the National REDD+ Programme. The National REDD + Steering Committee has been established to identify and propose relevant policies and approaches on issues relating to forest carbon and implementation of REDD+ initiatives in Vietnam to the Minister of MARD and the National Steering Committee for the National Target Programme on Climate Change, and coordinates with relevant line ministries, local authorities and organisations to implement REDD+ in Vietnam. It also directs the formulation and implementation of the National REDD+ Programme, relevant strategies and action plans, 


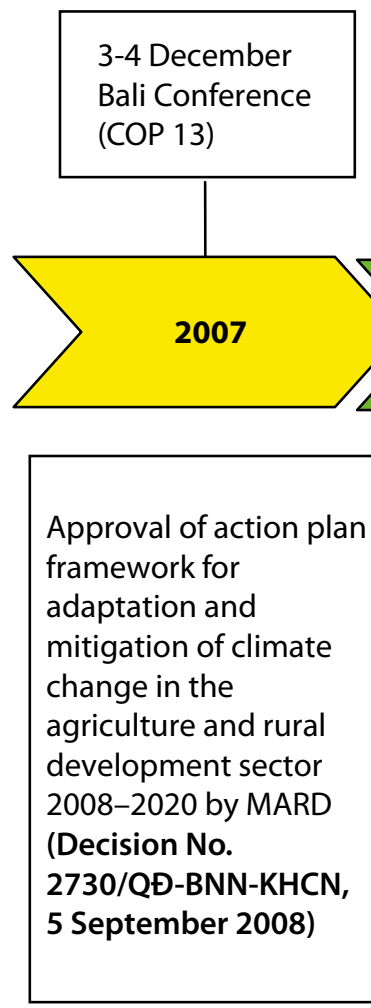

Approval of National Action Plan for adaptation and mitigation of climate change (Decision 185/2008/QĐ-TTg, 2 December 2008) by MONRE

10 April: Approval of Decision 380/QĐ-TTg on piloting payments for forest environmental services
February: Vietnam sends COPS secretary expression of interest and proposed methodologies and roadmap for REDD+ implementation in Vietnam
1 January: Price of water increased according to Decision 380
Establishment of five subtechnical groups: local implementation, BDS, MRV governance, private sector engagement

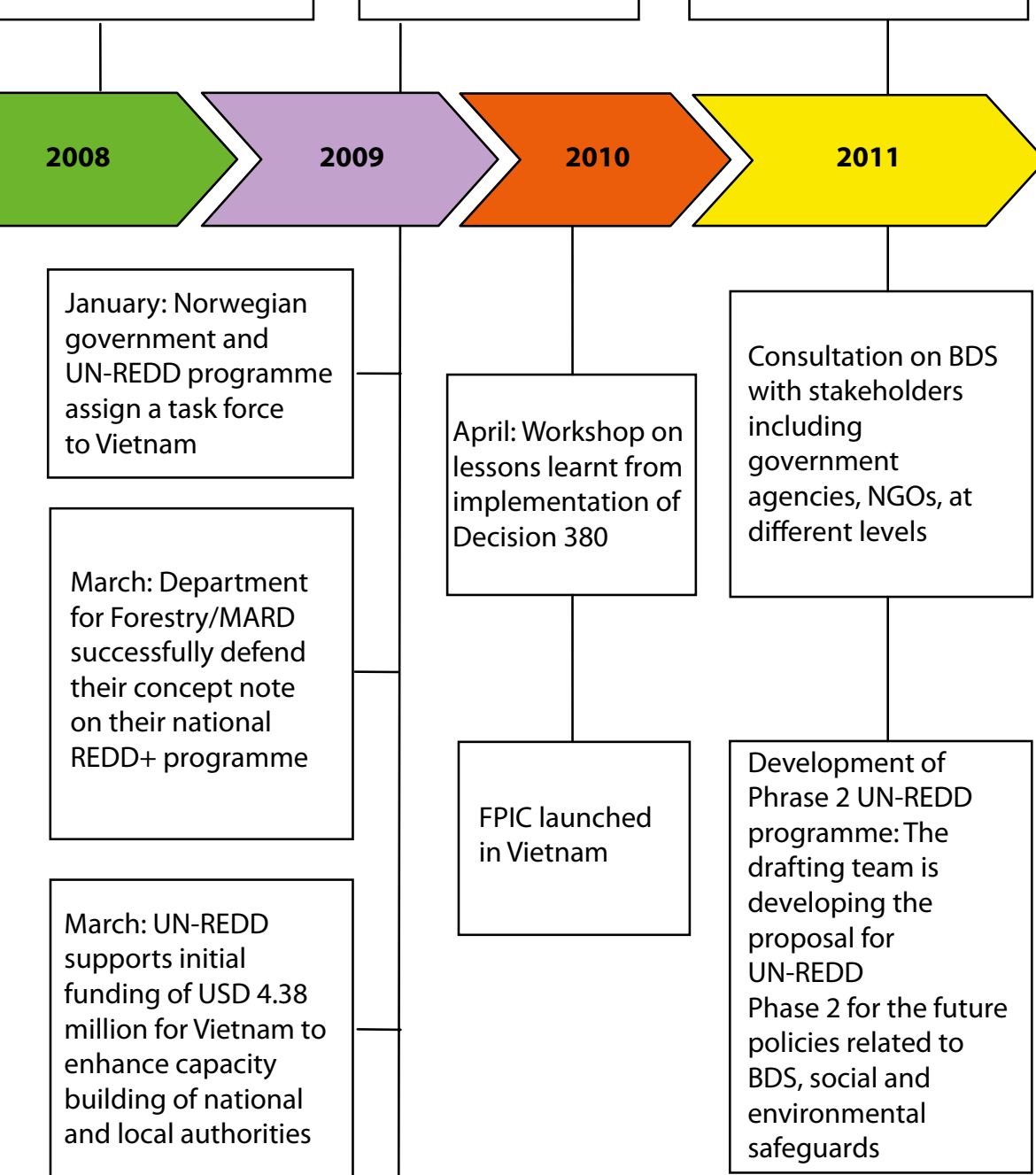

August: Regional Forum on Forest Carbon Partnership

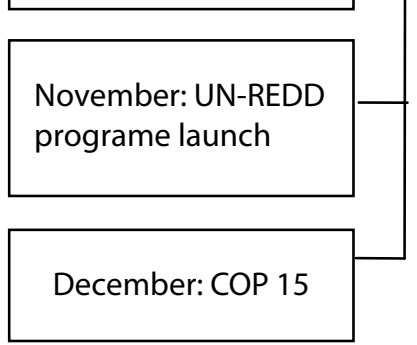

Development of Phrase 2 UN-REDD programme: The drafting team is Phase 2 for the future policies related to safeguards

\section{Figure 4.1. Timeline of Vietnam's main policies related to climate change and REDD+}




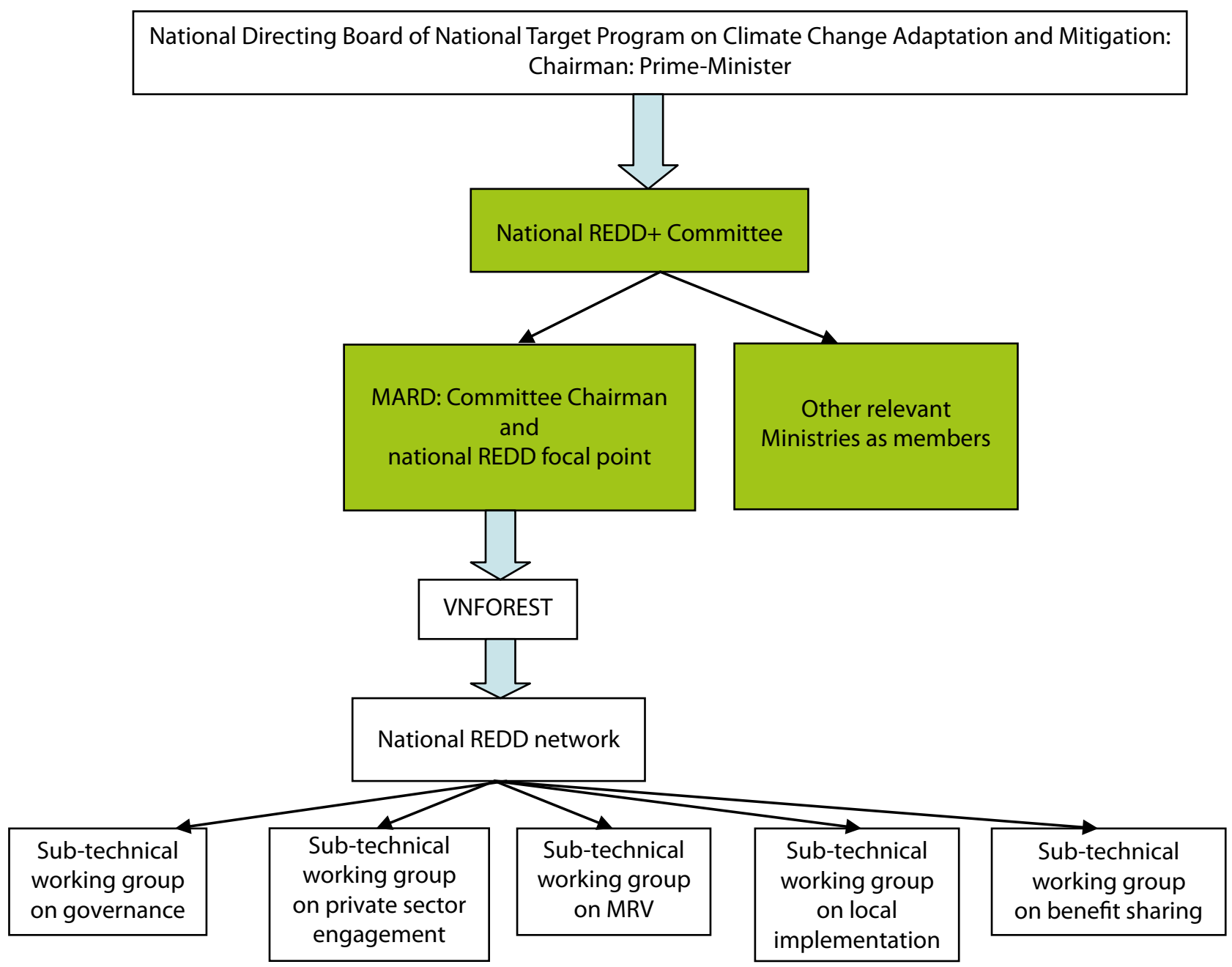

Figure 4.2. Institutional arrangement for REDD+ implementation in Vietnam

coordinates international cooperation activities to mobilise technical and financial resources for implementation of REDD+, and implements other REDD+-related tasks as designated by the Minister of MARD. In addition, a national REDD+ network was established in 2009 to provide an open forum for stakeholders including government agencies, multilateral and bilateral development partners, domestic and international NGOs and bilateral projects. The National REDD+ Office was also established in 2010 with the aim of coordinating REDD+ activities in Vietnam.

The complexity of the vertical and horizontal collaboration required among stakeholders poses a challenge for REDD+ implementation. In particular, the National REDD+ Office must work to synthesise the efforts of the multiple stakeholders involved. However, according to most interviewees, there is a lack of coordination because the National REDD+ Office has limited capacity and resources. It should also be noted that the private sector currently has little or no presence in the current structure. Much of the recent discussion has been devoted to this topic but it remains unclear as to how it will actually be translated into practice. Furthermore, although most interviewees agree that the MPI and MoFi have critically important roles in REDD+, their participation has been passive or their role has been overlooked in many important meetings.

\subsubsection{Implementation of REDD+ in Vietnam}

The Vietnamese government has emphasised that the founding principles for the REDD+ programme are that the nation's participation is voluntary, the programme is tailored to the specific 
Table 4.1. Institutional arrangements for the National REDD+ Programme

\begin{tabular}{llcl}
\hline Subtechnical working group & Launch date & $\begin{array}{l}\text { No. of meetings at } \\
\text { the time of writing } \\
\text { this report }\end{array}$ & Chaired by \\
\hline Forest and governance & 21 November 2011 & 1 & VNFOREST and FFI \\
Local implementation & 20 August 2010 & 7 & SNV and VNFOREST \\
MRV & 21 April 2010 & 10 & FAO and VNFOREST \\
Benefit-sharing mechanism & 28 April 2011 & 4 & VNFOREST and CERDA \\
Private sector engagement & 20 September 2011 & 1 & Forest Trends and VNFOREST \\
\hline
\end{tabular}

local conditions and that national sovereignty is not compromised. As REDD+ is regarded as a multidisciplinary and regional programme, it requires the active participation of a wide range of stakeholders. Policy reforms to improve coordination and collaboration and provide an effective and transparent mechanism should be on the agenda.

REDD+ has been mainstreamed in three major forestry policies in Vietnam: the National Forest Development Strategy 2006-2020; the National Forest Development and Protection Plan; and the Vietnam National REDD+ Strategy. ${ }^{10}$ The latter two were to be submitted to the Prime Minister for approval towards the end of 2011. The common aim of these policies is to modernise the forestry sector so that it can contribute to environmental protection and poverty reduction. REDD+ activities incorporated into the strategies are expected to provide financial incentives for environmental protection and to ensure co-benefits, such as poverty reduction, when combined with other PES schemes (GoV 2011). The REDD+ network covers a range of thematic areas, based on which five technical working groups were established to support the formulation of a National REDD+ Programme (Table 4.1).

The current institutional arrangements tell a unique story about REDD+ in Vietnam. First, the National REDD+ Programme is strongly supported by international donor organisations; all five working groups are co-chaired by international organisations. Second, the government perceives REDD+ as potentially contributing to poverty reduction and sustainable development and

10 The official name of the national REDD+ strategy is the 'National REDD+ Programme' in Vietnam (GoV 2011). therefore prioritised the launch of the working group on the benefit-sharing mechanism, making it the first working group after MRV. The later launch of the private sector engagement group shows that, despite recognition of the role of the private sector, determining ways to support and involve this powerful group remains a challenge not only at the stage of policymaking but also during REDD+ implementation. Although the Forest and Governance subtechnical working group received support from the government and stakeholders at the beginning of the REDD+ readiness phrase, it was not launched until November 2011. According to stakeholders interviewed, challenges in defining the concept of governance, the complexity of mainstreaming this concept into the other four subtechnical groups and the agreement over which international organisations would chair this working group are the main causes for this delay.

Our interviews suggest that the line between UNREDD and the National REDD+ Programme is blurred. UN-REDD aims to support the National REDD+ Programme and the government wants to use the UN-REDD programme as a blueprint. The problem of which comes first is evident in all processes and has been cited as the reason for reduced commitment and willingness among many stakeholders. In addition, although the five technical working groups are active and have already generated valuable outputs that could contribute to the National REDD+ Programme, these outputs have not been taken up by the government. This can be attributed in part to the fact that only a small number of government employees are participating in and committed to this network and in part to the unclear reporting mechanism from the working groups to higher levels. At the same time, information sharing among the five groups is limited. 
Table 4.2. Perceived advantages and disadvantages of financial options for REDD+

\begin{tabular}{|c|c|c|}
\hline Option & Advantages & Disadvantages \\
\hline $\begin{array}{l}\text { Option 1: Operate using existing } \\
\text { institution: Forest Protection and } \\
\text { Development Fund }\end{array}$ & $\begin{array}{l}\text { Reduced transaction costs of } \\
\text { establishing a new system } \\
\text { Avoids difficulties in operating a } \\
\text { new system arising from lack of } \\
\text { human resources } \\
\text { National, provincial and local } \\
\text { authorities and local people are } \\
\text { familiar with the procedures }\end{array}$ & $\begin{array}{l}\text { Fund Management Council lacks } \\
\text { the participation and support of } \\
\text { two important subjects: the buyer } \\
\text { and the seller. } \\
\text { The Forest Protection and } \\
\text { Development Fund is a state } \\
\text { financial institution, in which only } \\
\text { state agencies are involved, whereas } \\
\text { REDD+ requires the participation } \\
\text { of all stakeholders, including civil } \\
\text { society organisations }\end{array}$ \\
\hline Option 2: Establish a new system & $\begin{array}{l}\text { Complies with international } \\
\text { standards to ensure the revenue } \\
\text { and expenditure of REDD+ are } \\
\text { channelled towards REDD+ } \\
\text { activities only (i.e. the REDD+ Fund } \\
\text { should be independent of the } \\
\text { Forest Protection and Development } \\
\text { Fund) }\end{array}$ & $\begin{array}{l}\text { High costs are involved with } \\
\text { establishing a new system } \\
\text { State agencies do not have the } \\
\text { necessary capacity }\end{array}$ \\
\hline
\end{tabular}

The fact that REDD+ is seen in Decree 99 as part of the national PES programme has some implications for the future. First, being part of the national PES programme means that the REDD+ mechanism must be aligned with existing mechanisms. The current debate and options under consideration by the government concern whether to use the Forest Protection and Development Fund to manage REDD+ financial flows or to establish a totally new system that meets international requirements. Each option has its own advantages and disadvantages (Table 4.2) and is perceived differently by different stakeholders.

National and provincial stakeholders appear to prefer Option 1, whereas most international donors and organisations prefer Option 2. Aligning international organisations with the current national policy framework will continue to be a challenge for the National REDD+ Programme.

\subsection{Implications of REDD+ in Vietnam}

\subsubsection{REDD+ and indigenous people}

UN-REDD (2010) argues that a well-designed REDD+ programme can have significant benefits for indigenous communities. Instead of being forced out of preservation zones, these communities can take the role of forest protectors based on agreements with the government. Indigenous communities have accumulated knowledge and traditions for protecting the forest and could be offered payments and compensation for their efforts. However, despite national economic development growth, the 54 officially recognised ethnic groups within Vietnam do not receive equal benefits (Javier et al. 2008). In particular, the Kinh ethnic group still tends to have better access to information, options for development and benefits.

It is expected by interviewees that, for REDD+ to succeed, it must recognise and respect local peoples' rights and culture, as well as their participation. To date, NGO projects have made more progress than the government in terms of promoting community property rights. Nevertheless, while forest protection units managed by local authorities have worked very hard to implement state provisions, villages' and communities' rules and regulations regarding forest protection are respected and followed, although not always recognised, by local governments (Le 2009).

Vietnam's REDD+ objectives indicate a focus on areas that have experienced forest degradation and are at risk of deforestation. The stated 
priorities are reforestation, to ensure biodiversity conservation of the tropical forest, to increase forest carbon stocks and to implement sustainable forest management. Importantly, the focus areas are inhabited mostly by ethnic minority groups. The REDD+ programme therefore recognises the importance of involving ethnic minority groups, poor communities and women in REDD+, which includes prioritising their participation (Tebtebba 2010).

The FPIC trial in Lam Dong Province is evidence of the government's commitment to involving indigenous people in REDD+. However, ultimately, the REDD+ programme design will need to empower indigenous people by providing them with comprehensive information about both the opportunities and the constraints that REDD+ will potentially involve. The consultation process needs to be more effective, in terms of both the participatory methods used and the time devoted to discussion among community members (Nguyen et al. 2010).

\subsubsection{Benefit sharing in the context of PES and REDD+}

As discussed in Chapter 2, Decree 99 and the draft REDD+ strategy propose that local authorities, forest-dwelling communities, natural resource management boards and forest protection organisations should share the benefits from REDD+. However, experience from PES suggests that challenges will arise in applying benefit-sharing mechanisms, especially when payments are based on rights to forests. Sharing benefits derived from forests is always difficult. In some circumstances, conflicts arise between the government, with its land allocation efforts, and indigenous people, with their long tradition of using natural resources and forests. Transparency is an essential element for any REDD+ PES mechanism that seeks to bring real benefits to indigenous communities.

It is recognised that an MRV system ideally should include mechanisms to include households in carbon monitoring, especially those engaged in forest protection. However, government staff interviewed asserted that communities can only carry out simple measurements; experts are needed for precise and concise work.
Evidence that the government is focusing more on creating linkages between REDD+ and community forest management is a positive sign that the participation of communities is under consideration, but many challenges remain in ensuring that the poorest in the community can also share in the benefits (Le 2009).

\subsubsection{Proposed participation mechanism}

MARD recognises REDD+ as a multi-sectoral initiative requiring the active participation of all stakeholders. The establishment of the National Executive Board on Adapting to Climate Change, which is headed by the Prime Minister and includes representatives from MARD and MONRE, reflects the government's awareness of the need for ministries and sectors to work together. However, in reality, the division of responsibilities among ministries and sectors concerned with climate change adaptation activities is such that cooperation may not occur. Measures that could ensure effective and active participation of stakeholders in the design and implementation of REDD+ at local levels are mainly presented in the form of suggestions. At present, there is no indication that related activities run by local authorities have introduced the measures in practice. As a result, the effectiveness of participation mechanisms is very low (Le 2009).

\subsubsection{Linkages between PES and REDD+}

In analysing the national approach towards benefit sharing in Vietnam, Costenbader (2011) distinguished between PES and REDD+ and their related benefit-sharing mechanisms and suggested that REDD+ does not appear to readily integrate with PES for two reasons. First, PES buyers in Vietnam are entirely local (e.g. water utilities, industries or dam operators) and are legally obliged to pay, whereas buyers of REDD+ are mainly international donors or carbon buyers. Similarly, prices and monitoring procedures are determined locally and with a high level of discretion in the case of PES but under REDD+, prices are set by the global market or a fund, and monitoring is determined by international agreement. Second, PES funds may be pooled for various services (e.g. carbon, water, ecotourism), whereas REDD+ funds are kept isolated with safeguards in order to ensure accountability and help in the MRV of actions. 
However, Costenbader (2011) appears to have misunderstood the national PES policies. First, Article 4 of Decree 99 states that the types of forest environmental services stipulated include 'Forest carbon sequestration and retention, reduction of emissions of greenhouse gases through measures for preventing forest degradation and loss of forest area, and for forest sustainable development'. This means that in the Vietnamese context, the government does not perceive PES as part of REDD + but rather sees REDD+ as part of the PES policy. Given that Vietnam has reached the fourth stage of the forest transition curve (where reforestation is increasing forest cover), PES is perceived as a more appropriate instrument for protecting forests compared with REDD+. As a result, REDD+ is accepted as only one of the environmental forest services that need to be paid for under this policy. This view has been reinforced in many other studies, including UN-REDD and MARD (2010), as well as in the recently drafted National REDD+ Programme. Second, Article 6 of Decree 99 stipulates two payment methods for PES (which include REDD+ for both direct and indirect payments), as follows:

1. Direct payment:

(a) Direct payment occurs when users of forest environmental services pay directly to the suppliers of forest environmental services.

(b) Direct payment applies to cases where the users of forest environmental services are able and have sufficient conditions for making direct payment to the suppliers of forest environmental services without having to go through an intermediary organization. Direct payment is carried out based on the voluntary negotiated agreements between the users and suppliers of forest environmental services in line with the regulations in this Decree, where the payment level is not lower than the level regulated by the Government for the same forest environmental service.

2. Indirect payment:

(a) Indirect payment occurs when users of forest environmental services pay the suppliers of forest environmental services through the Vietnam Forest Protection and Development Fund or the provincial Forest Protection and Development Funds or agencies and organisations, decided by the Provincial People's Committee, acting in place of the provincial Forest Protection and Development Fund.

(b) Indirect payment is applied to cases where the users of forest environmental services are not able to and do not have sufficient conditions to make direct payment to the suppliers of forest environmental services but to make payment through an intermediary organization stipulated at Point a, Clause 2 of this Article. Indirect payment is subject to the intervention and support of the Government with prices of forest environmental services stipulated by the Government.

What Costenbader (2011) refers to, therefore, is indirect payments, where the state intervenes while the buyer (which could be either international or national) and sellers can negotiate direct payment; this is also the case with REDD+. Decree 99 also states that "The Government encourages the application of direct payment for all cases if suppliers and users of forest environmental services can reach agreement on the levels of payment.' The decree aims to ensure transparency, democracy and equity, to comply both with Vietnam regulations and with the international agreements and treaties that Vietnam has ratified.

Third, currently, the PES fund (i.e. the Forest Protection and Development Fund) is pooled from various sources (hydropower plant, ecotourism, water supply sources). Since REDD+ is considered part of PES, the latest draft of the National REDD+ Programme highlights the establishment of a REDD+ Fund directly under the Forest Protection and Development Fund, established and managed by MARD. In this sense, there is a strong linkage between REDD+ and PES in the Vietnamese context.

\subsection{Measurement, reporting and verification (MRV)}

According to the FCFP (2010) and McNally et al. (2009), remote sensing techniques have been used to monitor the forest cover in northern Vietnam since the 1970s. This work used 1:25000 aerial photos, with forest cover maps created at the 
same scale. By the end of 2007, the country used a ground receiving station that can both receive and process images. The government mandated the National Forest Inventory, Monitoring and Assessment Programme (NFIMAP) to take place every five years. This inventory, which was initiated in 1991, is presently in the fourth cycle (20062010) and all forested areas of Vietnam have been sampled. Each round of the NFIMAP has used different remote sensing equipment with later cycles using equipment with progressively better spatial and/or spectral resolution.

Many donors and international organisations have put significant effort and resources into forest monitoring in Vietnam (Tables 4.3 and 4.4). However, these projects support various Vietnamese governmental agencies and often do not come under the same ministry/department; hence, efficiency is sacrificed and redundancy and data hoarding occur.

The summary of work carried out to date indicates that, overall, monitoring activities in Vietnam remain scarce and short-term and lack continuity; there is no long-term, systematic and comprehensive programme (MONRE 2006). A critical lack is that there is no central repository of data that the government can maintain for use by all project developers; this is because of the lack of a monitoring network in combination with poor capacity and weak coordination and data-sharing among agencies (Doan 2009, FCPF 2010). The data on deforestation in Vietnam available from 1995 are relatively reliable but data on forest degradation and forest quality are poor (Doan 2009, FCPF 2010). Methods used for the forest land inventory are based on both field surveys and ground truthing for prioritised areas or data from a previous inventory as baseline data, rechecked using remote sensing techniques (Pham et al. 2009, Hoang et al. 2010).

In-depth analysis of the current MRV system in Vietnam by Hoang et al. (2010) highlighted two major challenges that need to be addressed for future REDD+ implementation: 1) inconsistencies in land use classification; and 2) inconsistencies in forest-related land use data and changes in forest cover.

\subsubsection{Inconsistencies in land use classification}

Two official land use classification systems are operating in Vietnam: that of the GDLA under MONRE, which focuses primarily on land use management and planning, and that of FIPI under MARD, which focuses on forest management. This situation creates inconsistencies between existing land use 'categories' and inconsistencies in the available forest data (Hoang et al. 2010). Such inconsistencies complicate efforts to determine the most appropriate land use 'legend' or classification for the country for REDD+ accounting and monitoring (Table 4.5).

Both systems include data on the total area under the three types of forest management as well as areas where natural forest is distinguished from plantation forest. However, the most significant difference between the two systems is the 'forest identity' of 'unused land' in the GDLA and 'bare land, mountain without forest', also referred to as 'forest land without forest' in the Forest Protection Department.

\subsubsection{Inconsistency in forest-related land use data and changes in forest cover}

The differences in the total area classified as forest in 2005 and 2007 were 4 million ha and 2.7 million ha, respectively, because of the difference in land categories employed by the two institutions. The cause of these differences is that areas classified as 'forest land without forest' under the MARD system are classified as 'unused land' plus land for forest regeneration under the GDLA system (Table 4.6). Indeed, natural forest appears to be the only category for which the two systems provide consistent figures.

The figures on changes in forest cover also differ between the two systems. The MARD data given in Table 4.6 show no change in the area of natural forest in 2005 and 2007, while GDLA data showed a decrease of $38,000 \mathrm{ha}$. It is unclear what data the estimations are based on and whether the same land areas have been given different land use characteristics or classifications in the two systems (Hoang et al. 2010). 
Table 4.3. Vietnam's four rounds of forest inventory

\begin{tabular}{llclc} 
Years & Sensor & Resolution & Data & Number of ground plots \\
\hline $1991-1995$ & Landsat TM & $30 \mathrm{~m}$ & Hard copy only & 4200 \\
$1996-2000$ & SPOT & $20 \mathrm{~m}$ & Digital & 4200 \\
$2001-2005$ & Landsat ETM & $30 \mathrm{~m}$ & Digital & 4200 \\
$2006-2010$ & SPOT 5 & $10 \mathrm{~m}$ & Digital & 2100 \\
\hline
\end{tabular}

Source: McNally et al. (2009)

Table 4.4. Stakeholders and their activities in MRV in Vietnam

\begin{tabular}{|c|c|}
\hline Actors & Activities \\
\hline \multicolumn{2}{|l|}{ International agencies } \\
\hline Forest Agency of Japan & $\begin{array}{l}\text { Testing the potential applications of the Japanese Advanced Land Observing } \\
\text { Satellite (ALOS)/PALSAR data to establish forest cover maps and to estimate forest } \\
\text { carbon stock in two provinces }\end{array}$ \\
\hline Finnish government & $\begin{array}{l}\text { Developing a more reliable forest inventory information platform } \\
\text { Establishing a more accurate forest stock baseline (FORMIS) } \\
\text { Supporting MARD in developing RELs }\end{array}$ \\
\hline $\begin{array}{l}\text { USAID Asia Regional } \\
\text { Biodiversity } \\
\text { Conservation Program } \\
\text { supports Winrock } \\
\text { International }\end{array}$ & $\begin{array}{l}\text { Developing a forest protection project (USD } 6 \text { million for 2005-2009), which } \\
\text { includes a project-based REDD+ initiative that uses Quickbird technology to } \\
\text { estimate the forest carbon modelling of an } 80000 \text { ha watershed forest in the Da } \\
\text { Nhim basin of Lam Dong Province }\end{array}$ \\
\hline JICA & $\begin{array}{l}\text { Developing digital maps (maps of 1990, 2000, } 2010 \text { including validation) and } \\
\text { digitisation/processing of NFI (cycles 1, 2, } 4 \text { including validation) } \\
\text { Conducting model land survey } \\
\text { Estimating RELs (using five points 1990-1995, 2000, 2005, 2010) and the costs and } \\
\text { benefits of AR-CDM and REDD+ } \\
\text { Providing information to potential investors } \\
\text { Compiling comprehensive and accurate forestry data: modification and validation } \\
\text { of forest maps } 1995 \text { and } 2005 \text { (partly done by NORDECO); field survey and } \\
\text { validation cycle of NFI cycle 4; estimation of RELs (based on three sets of time series } \\
\text { data and five sets of time series data) and compare their accuracy/cost-benefit }\end{array}$ \\
\hline SNV & $\begin{array}{l}\text { Proposing an approach that stratifies forest areas into different levels of growth or } \\
\text { degradation combined with ground surveys within each of these groups; based on } \\
\text { that, generating relationships between these categories of forest and their spectral } \\
\text { characteristics on satellite images, thus enabling detection of transition between } \\
\text { the categories and estimation of associated emissions }\end{array}$ \\
\hline
\end{tabular}

\section{National agencies ${ }^{\mathrm{a}}$}

Forest Inventory and Planning Institute (FIPI) under MARD
Manages a set of permanent sampling plots that are measured every five years. Different ecological zones are sampled in different years to make efficient use of labour; however, a particular zone will always be sampled in a single year, and sampling events for the zone will be five years apart. A permanent set of 4200 plots were sampled for the first three cycles of NFIMAP; however, with the higherresolution SPOT 5 imagery being used in the current cycle, FIPI decided to scale down the number of ground plots by half.

Focuses primarily on land management, including current land use and land use planning. GDLA conducts land use inventories every five years based on the National Land Registration System, ground surveys and annual land use statistics.
General Department of Land Administration (GDLA) under MONRE

a Central, provincial, district and commune units of General Department of Forestry (GDOF) at the MARD prepare annual monitoring reports on forest coverage, using FIPI data as a baseline. These reports are compiled by the Forest Protection Department at GDOF into annual national forest cover statistics (R-PINs). 
Table 4.5. Comparison of two land use classification systems operating in Vietnam

\begin{tabular}{ll}
\hline \multicolumn{2}{l}{ GDLA land use classification } \\
\hline 1 & Agriculture \\
1.1 & Agriculture production land \\
\hline 1.2 & Forestry land \\
1.2 .1 & Production forest \\
1.2 .2 & Protection forest \\
1.2 .3 & Special-uses forest \\
\hline 1.3 & Aquaculture land \\
1.4 & Salt production \\
1.5 & Other agriculture land \\
2 & Non-agriculture land \\
3 & Unused land \\
4 & Coastal wetland (observed) \\
\hline
\end{tabular}

\begin{tabular}{|c|c|c|}
\hline \multirow{3}{*}{$\begin{array}{l}\text { Forest land } \\
\text { in both } \\
\text { categories }\end{array}$} & \multicolumn{2}{|c|}{ FPD land use classification } \\
\hline & I & Forest \\
\hline & A & Natural forest \\
\hline & A1 & Forest (wood stock) \\
\hline \multirow{8}{*}{$\begin{array}{l}\text { FPD: Forest } \\
\text { land without } \\
\text { forest } \\
\text { GLDA: Unused } \\
\text { land }\end{array}$} & $\mathrm{A} 2$ & Bamboo forest \\
\hline & A3 & Mixed forest \\
\hline & A4 & Mangrove forest \\
\hline & A5 & Rock mountain forest \\
\hline & B & Planted forest \\
\hline & B1 & Planted forest (w/wood stock) \\
\hline & B2 & Planted forest (w/o wood stock) \\
\hline & B3 & Bamboo forest for production \\
\hline \multirow{8}{*}{$\begin{array}{l}\text { Other land } \\
\text { uses }\end{array}$} & B4 & Specialty tree \\
\hline & II & Bare land, mountain without forest \\
\hline & $\mathrm{C} 1$ & la (grass, cane) \\
\hline & $\mathrm{C} 2$ & Ib (scattered brush, tree, bamboo) \\
\hline & C3 & Ic (a lot of re-growth wood trees) \\
\hline & $\mathrm{C} 4$ & Rock mountain without forest \\
\hline & $\mathrm{C} 5$ & Sandbanks, swamps etc. \\
\hline & III & Other land \\
\hline
\end{tabular}

Table 4.6. Areas of forest-related land use categories according to GDLA and FPD data, 2005 and 2007

Unit: '000 ha

\begin{tabular}{|c|c|c|c|c|c|c|}
\hline \multirow[t]{2}{*}{ Category } & \multicolumn{3}{|c|}{2005} & \multicolumn{3}{|c|}{2007} \\
\hline & GDLA data & FPD data & Difference & GDLA data & FPD data & Difference \\
\hline Total forest area & 15024 & 19029 & -4004 & 15174 & 17847 & -2673 \\
\hline Natural forest & 10251 & 10283 & -312 & 10213 & 10284 & -71 \\
\hline Planted forest & 3339 & 2334 & 1006 & 3786 & 2553 & 1232 \\
\hline $\begin{array}{l}\text { Land for forest } \\
\text { regeneration }\end{array}$ & 1434 & - & 1434 & 1175 & - & 1175 \\
\hline $\begin{array}{l}\text { Forest land } \\
\text { without forest }\end{array}$ & - & 6412 & -6412 & - & 5010 & -5010 \\
\hline Unused land & 5066 & - & 5066 & 4732 & - & 4732 \\
\hline Other land & 13420 & 13991 & -571 & 13609 & 14660 & -1051 \\
\hline Total country area & 33510 & 33020 & 490 & 33515 & 32507 & 1008 \\
\hline
\end{tabular}

\subsubsection{Other limitations to MRV}

Another issue with MRV is that there is no system for measuring the impacts and outcomes of existing policies. Many interviewees noted that, despite the importance of the FLA policy, no monitoring mechanism has been established. As a result, about $70 \%$ of local people have not complied with the law in using the forest resources on their forest land. There is limited information indicating how much of this illegal logging 
activity occurs on a small scale, and how it might be contributing to poverty alleviation (Sunderlin and Huynh 2005). Sunderlin and Huynh (2005) highlight that the punishments of violations related to forest burning are not very stringent and most people consider forest burning a normal activity. Forest resources are overexploited; new forest plantations cannot keep up with the intensive illegal logging and destruction. Punishments for violations are too lenient and are incompatible with the respective legal provisions.

The system of controlling and monitoring the timber flow in Vietnam also exhibits several weaknesses. Domestically produced timber is produced from both natural forests and plantations with slightly different systems of control (see ProForest 2009 for further details). As a result, although the regulations and the allowed volume are clear, it is unknown just how much industrial roundwood is produced from Vietnam's forests each year and there is no available information on how much industrial roundwood is produced from plantations, or by smallholders or state and private enterprises (ProForest 2009).

\subsubsection{Carbon mapping}

In terms of carbon mapping, Vietnam is at a fairly basic stage. The national government has no spatially explicit information on carbon stocks. The only data on emissions from land cover change were derived from scaling-up the gross deforestation values using standard IPCC values to estimate tonnes of $\mathrm{CO}_{2}$ per ha of forest. These values are generalised across various types of landscape and forest, and so for any given area are very approximate. Researchers have attempted to measure the amounts of aboveground carbon stock and biomass but mainly for planted forest; very little research and evaluation is taking place for underground biomass and natural forest. JICA and $\mathrm{SNV}$ are leading agencies in mapping out land eligible for REDD+. In particular, SNV's work conducted by McNally et al. (2009) and Holland and McNally (2010) (see Figures 4.3 and 4.4.) make a great foundation for future work. The authors suggest that REDD+ activities should focus on those areas that have significant remaining stocks of forest carbon and are under threat from deforestation or degradation

FAO (2010) has also provided figures on carbon stocks (Figure 4.5), which show a slight increase in the carbon stock in the living forest biomass in Vietnam. 


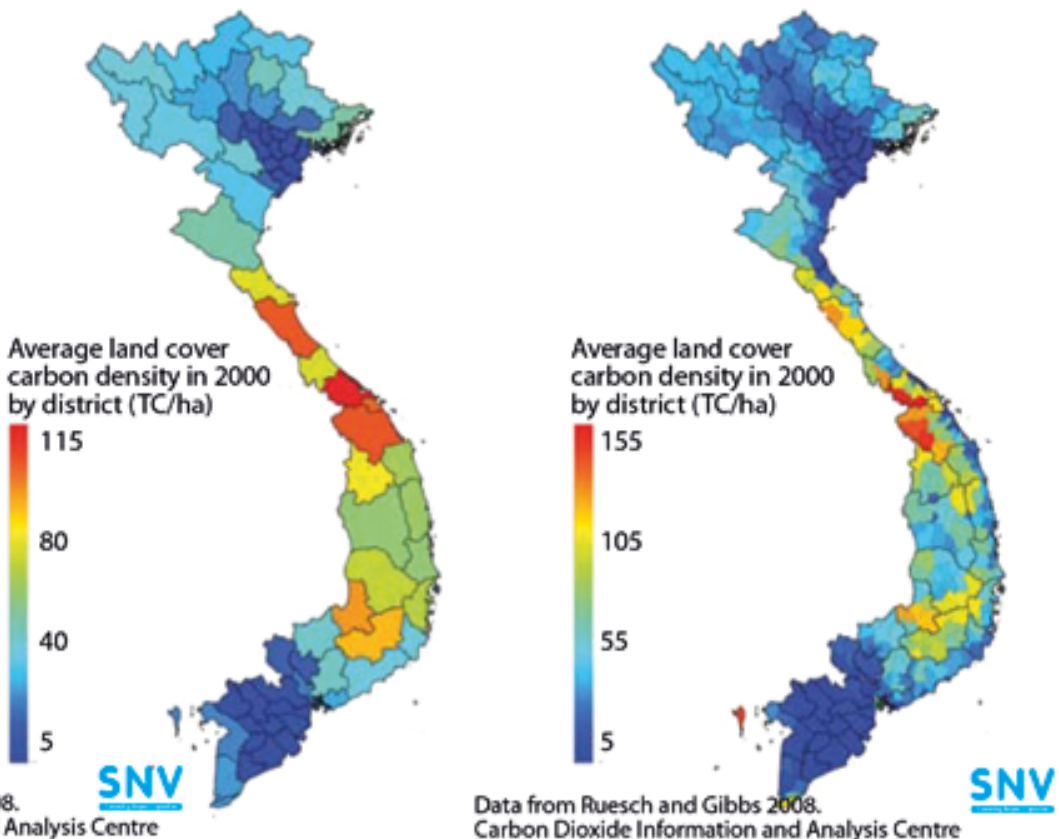

Data from Ruesch and Gibbs 2008 .

Carbon Dioxide Information and Analysis Centre

http://cdiac.ornl.gov/epubs/ndp/global_carbon/carbon_documentation.html http://cdiac.ornl.gov/epubs/ndp/global_carbon/carbon_documentation_html

\section{Figure 4.3. Average land cover carbon density in 2000 by province and district}
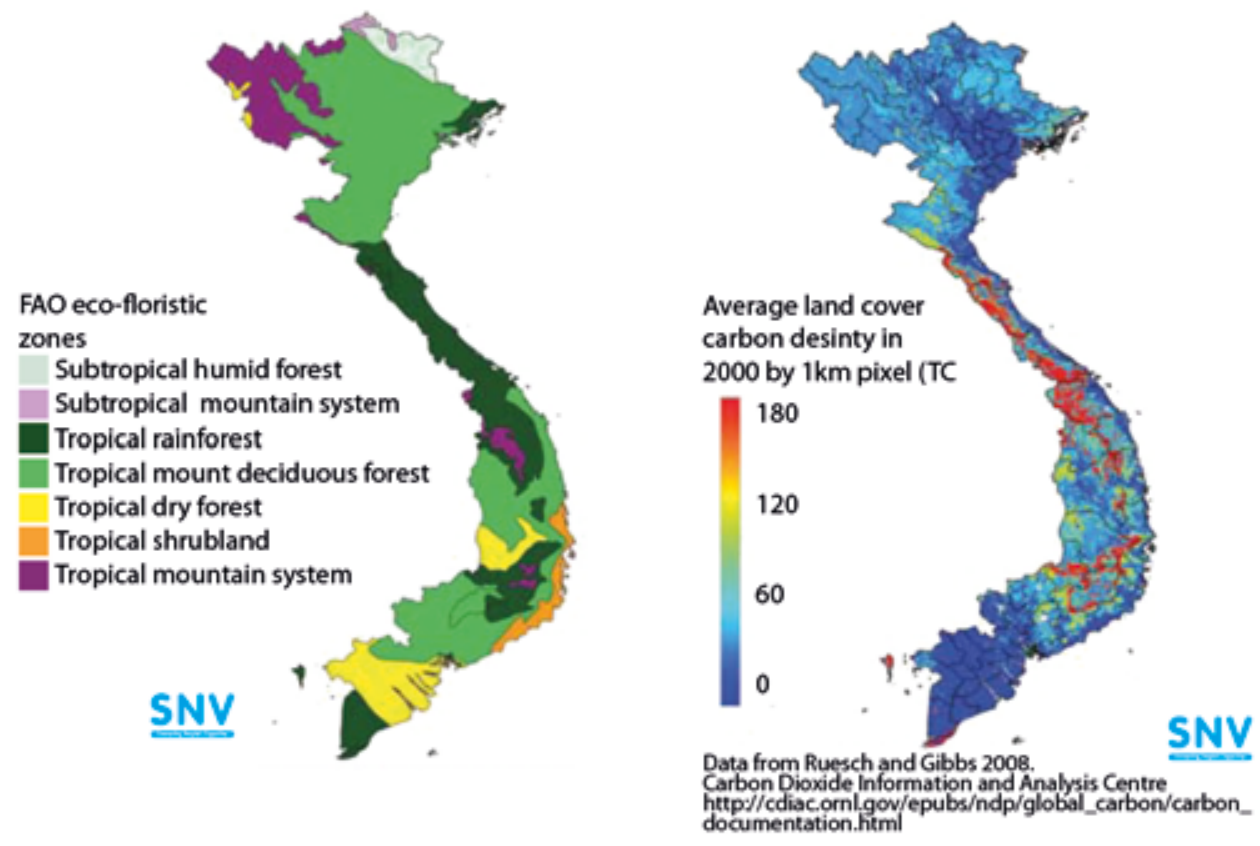

Figure 4.4. Land cover carbon density in Vietnam, 2000

Source: SNV 

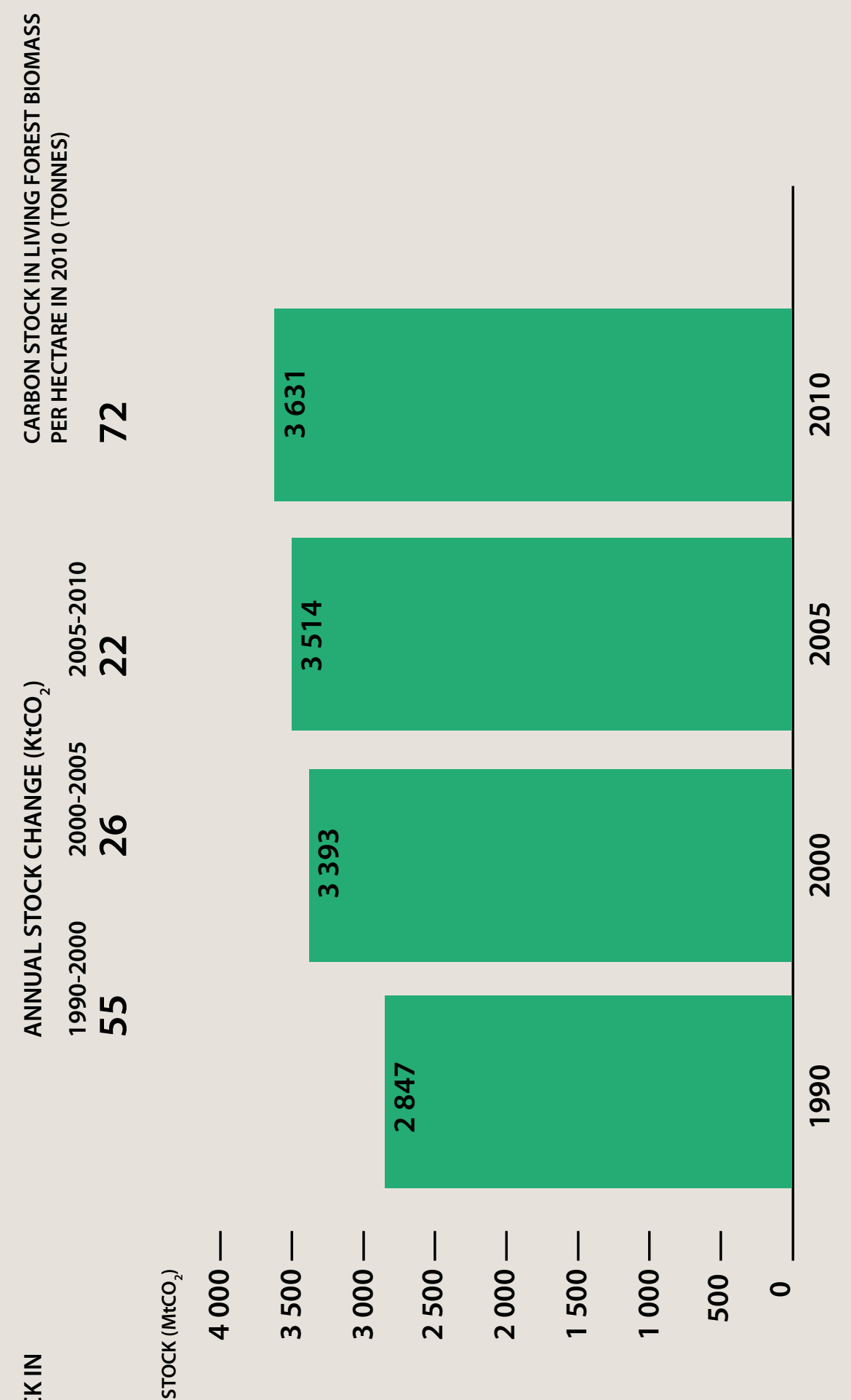

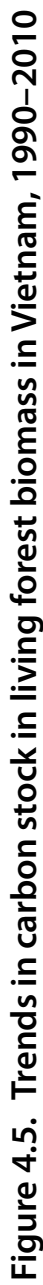

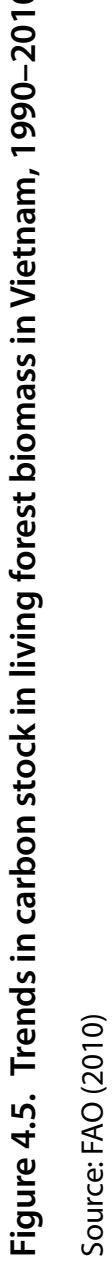




\section{The 3Es and REDD+ implementation in Vietnam}

$\mathrm{T}$ This chapter draws on the analyses and findings in previous chapters to make an overall assessment of the Vietnamese context in relation to REDD+ and offers suggestions for the future implementation of REDD+ in Vietnam. The following sections evaluate REDD+ in Vietnam using the ' $3 \mathrm{E}$ 's (effectiveness, efficiency, equity) as an analytical framework:

- Effectiveness: Can present policies in general, and policies on REDD+ in particular, reduce deforestation and forest degradation? In return, can REDD+ contribute to national efforts to reduce deforestation and forest degradation?

- Efficiency: Will REDD+ be implemented with the least cost possible?

- Equity: Will benefits and costs be shared equally among stakeholders and will the poor benefit from REDD+ policies?

Five major areas of REDD+ are assessed within this 3E framework: 1) deforestation and forest degradation policies; 2) measurement, reporting and verification (MRV); 3) institutional arrangements; 4) coordination and commitment; and 5) benefit-sharing mechanisms. The aim of this assessment is to gauge the government's readiness to respond to REDD+ and to propose essential interventions to support REDD+ implementation in Vietnam.

\subsection{Deforestation and forest degradation policies}

Chapter 1 identifies four direct drivers and three indirect drivers of deforestation and forest degradation. The direct drivers are 1) land conversion for agriculture; 2) land conversion for infrastructure; 3 ) logging (illegal and legal); and 4) fire. The indirect drivers are 1) the pressure of population growth and migration; 2) the state's weak forest management capacity; and 3) the limited funding available for forest protection. These drivers and their impacts vary from region to region, and change over time; this suggests that no 'one-size-fits-all' formula will function across the whole of Vietnam. Instead, the government needs to determine the main principles and general policy but allow individual programmes to be designed and implemented based on local drivers and socio-economic needs (e.g. infrastructure development, agriculture development, land conversion), while also meeting demand from international markets (e.g. increasing demand for seafood and wood products), as discussed in detail in Chapter 3.

The Vietnamese government has developed various policies and programmes targeting a reduction in deforestation and forest degradation; these include the national reforestation programme, Programme 661 (also known as 5MHRP); the land allocation programme; the National Forest Development Strategy; and Decision 380 and Degree 99, which aim to enhance payments for forest environmental services. These policies have contributed towards mitigation of deforestation and forest degradation, as reflected in the net increase in forest cover in Vietnam over time (see Chapter 2).

However, these initiatives have several shortcomings. First, although forest cover has 
increased during the past two decades, the quality of the forests has decreased. The area of degraded forest has increased and, even though new forest has been planted, forest density overall has declined. Carbon stocks are therefore lower (Meyfroidt and Lambin 2008). This outcome shows that simply increasing the forest area through reforestation is not sufficient to rehabilitate the different ecosystem functions and services of forests, especially with regard to carbon stocks (Meyfroidt and Lambin 2008). This poses a serious challenge both for biodiversity conservation and for the role of forests in providing services as carbon sinks to mitigate climate change.

Second, despite excellent policy objectives and intentions on paper, practical implementation has been characterised by numerous failures and weaknesses (Thomas et al. 2008). Many policy measures are compromised by limited funding for forest protection, weak local governance capacity, poor vertical and horizontal coordination, low involvement of the poor, women and indigenous groups, low economic returns, elite capture of land and benefits and corruption (see Chapters 1 and 2). Despite widespread awareness of these issues and concerted efforts by the government and donors to address them, effective solutions are yet to be found.

Third, many development policies have not been scrutinised in terms of their potential unintended effects. That is, a policy released to address one problem may in fact end up causing another problem. For example, in addressing the problem of unequal population distribution - a legacy of colonialism - the relocation policy led to increasing deforestation in resettlement areas.

Fourth, while several policies related to REDD+ have been released and are currently being piloted across the country (Chapter 4), REDD+ policy needs improvement in two main areas: 1) provisions on benefit sharing and PES; and 2) procedures for assessment, approval and provision of carbon rights. Improvement in these areas requires careful analysis of Vietnam's existing institutions, as well as the projected future demand and supply curve of international and national carbon markets. It is also important to acknowledge the fact that drivers of deforestation and degradation in Vietnam differ across space and time. The analysis in this study highlights that the main reasons for deforestation and forest degradation - land conversion and poor governance - are difficult to tackle.

The policy environment regarding forests and forestry in Vietnam can be characterised as fluid and dynamic. Policy development during the past decade has spanned a wide spectrum of divergent - and to some extent antagonistic concerns. Many of the changes in policy have come as conclusions drawn from field experience in both international and national programmes. International cooperation programmes have introduced participatory methods, village-level planning and environmental concerns on a large scale. Lately, innovative consultative methods have been developed and refined as part of the poverty eradication efforts (Sunderlin and Huynh 2005). It is now widely accepted that policies that withdraw productive assets from local - often poor - people, without offering viable replacements, cannot be sustainable, and run the risk of becoming increasingly unpopular.

Yet, despite the recognition of the strong link between poverty and deforestation, this issue has not been adequately addressed. Despite acceptance of the principle that planning should be participatory, the fundamental questions regarding the rights to the products from the forests are still controversial. Such questions pertain even to the new possibilities that have opened up. For example, as shown above, forest land allocation by itself does not always help lift the poor out of poverty.

In terms of efficiency, on the one hand, the government budget is not sufficient to cover all expenses related to policy and programme implementation. On the other hand, high transaction costs also reduce the efficiency of policy implementation; these transaction costs arise because of poor coordination and overlapping functions among ministries, lack of transparent financial monitoring and complex financial procedures. Moreover, the actual costs have not been calculated, which can potentially lead to misuse of the funds. In addition, the significant financial support for Vietnam's deforestation and forest degradation policies so far received from external donors (e.g. the World Bank, the 
Asian Development Bank [ADB], the Food and Agriculture Organization of the United Nations [FAO]) has not been used effectively. Much of the funding has been spent on administration fees and international consultant fees rather than on actual implementation activities. Future REDD+ schemes should assess these factors carefully during their design.

Moreover, balancing the supply and demand of timber and raw materials for the wood-processing industry - a government priority - will continue to be a challenge. On the one hand, there has been rapid growth in the wood-processing subsector involving both small and medium enterprises and industrial-scale enterprises. On the other hand, the production subsector (economic plantations) has been stagnant for many years. The forestry sector cannot meet the increasing demand for timber and other forest products for export and domestic consumption. For example, the fact that $80-90 \%$ of timber used for export products has to be imported puts these industries in a vulnerable situation. Meeting the demand for export and domestic consumption of timber and NTFPs is a challenging task for the sector, and has important implications for future research, education, training and extension (Doan et al. 2005).

The pressure that leading agricultural commodities such as rubber and coffee place on forest will also create great difficulties for the government in managing its environmental and economic development goals.

As explained in Chapter 4, two proposals for managing and channelling REDD+ funding are under discussion by stakeholders and government. The harmonisation of these two proposals in a way that addresses both national and international requirements will require gradual adjustment and should not rushed, particularly given that global negotiations have still not been concluded.

In terms of equity, as presented in Chapter 2, the current laws list eight major stakeholder groups that benefit from the use of forest land: stateowned forest companies; households; protection forest management boards; management boards of special-use forests; local communities; PCs; private companies; and the army. However, the forest area under the management of households is relatively small (Hoang et al. 2010, Nguyen et al. 2010), while state enterprises manage a large area of rich forests. This indicates that REDD+ payments will mainly benefit state agencies, whereas households and other actors will be able to access only a small proportion of the money.

One basic problem is the difficulty for local communities to meet all the requirements for gaining forest use rights: being legally established; having a formal organisational structure; having assets independent of those of other organisations and individuals, and being responsible for those assets; and being able to participate in legal relationships independently and in their own name (Hoang et al. 2008). There is no doubt that FLA and the recognition of land use rights through the 2004 Law on Forest Protection and Development are major achievements in Vietnam's forestry sector. However, ongoing challenges include land allocation in a more transparent and equitable manner and provision of better extension services to help local people understand their rights and duties (Nguyen et al. 2008). The study also shows that equity is perceived differently by different groups, which could prove an obstacle in designing and implementing REDD+ in an efficient and effective way.

Vietnam's current deforestation and forest degradation policies create a legal platform for REDD+ development, as they demonstrate the government's commitment and support in relation to leakage, benefit-sharing mechanisms, monitoring and good governance. The emergence of REDD+ also emphasises the need to reduce deforestation and forest degradation and can encourage government interest in embracing the new financial opportunities that forest protection and development may generate.

\subsection{Measurement, reporting and verification}

The subtechnical working group on MRV, which is chaired by FAO with active participation by government agencies and international NGOs, is drafting an MRV design for Vietnam's National REDD+ Programme. However, the level at which this system would be applicable is unclear. Monitoring has tended to be neglected in Vietnam, and instituting a more efficient and effective 
system, as required by REDD+, will be a challenge. Several issues need attention, as described in the following sections.

\subsubsection{Forestry data}

Consistency in the land classification system is critical for REDD+, because monitoring, reporting and assessment will be based on changes in forest cover over time and REDD+ benefit sharing depends on land use registration data.

\section{Central data management}

Vietnam currently has two databases on land classification and administration. The first database, maintained by the General Department of Land Management under MONRE, contains information related to land management, including land area and land use planning. The second database, managed by VNFOREST under MARD, defines forest and forest land categories and contains data on the extent of forest coverage, which are collected by FIPI. Two official land use classification 'legends' co-exist in Vietnam, mainly for management purposes; however, this may complicate efforts to determine the most appropriate land use 'legend' or classification system for the country for REDD+ purposes (Hoang et al. 2010).

Furthermore, the current data only reflects technical aspects, socio-economic factors relevant to REDD+ have been neglected. In addition, although data on deforestation in Vietnam is available, there is a serious shortage of data on forest degradation. This might lead to distortions in assessing REDD+ impacts on communities and on overall improvements in forestry. Existing data are inconsistent, creating great difficulties for the government in identifying indicators for emission reductions.

MARD and MONRE are planning to merge these two systems into a national database, which promises to be a time-consuming and costly process. The launch of REDD+ and its strict MRV requirements have accelerated this process and funding from donors has been channelled into this area.

\section{Local data collection}

The quality and accuracy of the data collected depend mainly on the organisations (MARD and FIPI) and local officials that conduct the surveys and report their findings. Although data collection is conducted periodically at the local level, the quality is often not assured. This is because, first, funding for fieldwork is limited. As a result, in many areas, researchers do not visit the field but base their reports on secondary data or their own estimates. Second, monitoring and evaluation of the performance of FLA and of postallocation forest leases and use are not undertaken regularly, leading to poor data on these key assessment criteria.

With significant support from donors and international organisations, basic carbon maps and different Reference Emission Levels for Vietnam have been proposed. However, such support has been directed into different government agencies and is sometimes overlapping, leading to weak synthesis of both resources and efforts.

\subsubsection{Mechanisms for reducing 'leakage'}

'Leakage' is a central issue for REDD+ implementation at both national and regional levels (Angelsen 2008). The main sources of leakage in Vietnam are: 1) regional/cross-boundary and national illegal logging; and 2) conversion of forest land to industrial tree plantations (Hoang et al. 2010).

Leakage issues remain the most difficult in terms of both data collection and political debate. It was envisaged by most interviewees that Vietnam would establish an intergovernmental forum to address the regional aspects of REDD+ readiness and implementation. The forum was deemed necessary particularly given the cross-border nature of the drivers of deforestation and forest degradation within the region and the consequent problems of displacement of activity (leakage) and incomplete mitigation strategies unless international aspects are recognised and addressed. The UN-REDD Programme aims to quantify displacement probability across country borders through compiling and analysing existing data as well as through regional dialogue. Vietnam also plans to establish a Mekong REDD Commission with the purpose of creating an inter-governmental partnership of Mekong River countries to avoid the risk of emissions displacement under REDD. A project concept note for the creation of a technical support body with this aim was drafted and submitted to the 2 nd Meeting of the 
Participants Committee of the FCPF in Panama in March 2009. MARD Minister visited Lao in October 2011 and both sides agreed to develop a comprehensive cooperation programme, including REDD+, FLEGT, capacity building, afforestation, and forest monitoring. The Ministry of Industry and Trade will take a lead in developing a bilateral trading agreement, including transparent procedures for timber export and import. A MARD minister visited Cambodia in early December 2011 and agreed to urgently develop an $\mathrm{MoU}$ for combating illegal logging and cross border transportation. Discussions have continued but an agreement has not yet been reached between the four potential members - Cambodia, Vietnam, Lao PDR and Thailand (Scheyvens 2010).

To address illegal logging, Vietnam and other countries in the region are coordinating efforts through the Forest Law Enforcement, Governance and Trade (FLEGT) scheme, but the focus is on 'trade' rather than broader issues of governance. Moreover, as this commitment is voluntary, no specific policy solutions have been formulated. Addressing illegal logging might also have adverse effects on the local people whose livelihood depends on it (Pham et al. forthcoming). Addressing the second source of leakage requires the government to conduct a trade-off analysis and harmonise its goals for economic development and environmental protection. Ultimately, Vietnam's capacity to reduce emissions mainly depends on the implementation of policies on natural resources management, economic development and REDD+. Furthermore, as Hoang et al. (2010) point out, although Vietnam is often held responsible for deforestation and degradation in its neighbours, Lao PDR and Cambodia, the reality is more complex than generally depicted and requires a comprehensive assessment.

During the late 1990s, many Vietnamese companies producing furniture, depended largely on timber harvested, probably illegally and unsustainably, from forests in Laos and Cambodia. A number of those companies opted to continue operating in Vietnam but switched to sources that were legal, demonstrably progressing towards sustainable management (ProForest 2009). Vietnam will still have to rely on imports to meet its raw material requirements, especially for the furniture industry, because domestic plantations mainly produce small-diameter logs, which are more suitable for woodchips. Vietnam's current major timber supplies originate from sources with a high risk of illegality, meaning that control of legality of imported timber is essential (ProForest 2009). Currently, the government is negotiating a VPA with the EU and is working on improving its legal framework to address this issue. This shows commitment from the government but might not ensure that the complexity of the problem is solved.

\subsubsection{Technical capacity}

Formal forestry education in Vietnam was established more than 60 years ago and the country has a large number of well-trained professional and technical staff. However, as a new field, REDD+ requires new technical skills, such as for measuring underground carbon stocks, defining emission baselines and assessing and approving carbon credits; the knowledge and skills of existing staff are limited in these areas. Even FIPI, which is one of the main agencies collecting forest data in the country, experiences difficulties in carrying out new tasks. In addition, Vietnamese organisations and agencies are not eligible or authorised to verify carbon certification. As a result, the country has to hire international organisations to do the job, which often absorbs most of the operating costs. However, with growing support from international donors and international research institutes, it is expected that the technical capacity of national agencies will be strengthened over time.

More important, however, is the capacity to adapt and be innovative. A bureaucratic structure such as that found within Vietnam's forestry institutions is very difficult to change - yet change is necessary for a new concept such as REDD+, which requires new approaches and a new way of thinking.

\subsubsection{MRV costs}

Measurement, reporting and verification are costly activities, accounting for $5-60 \%$ of total project expenses. Donors cover the bulk of these costs; however, this could become problematic in the future when national projects need to bear the costs themselves. A thorough cost-benefit analysis should be undertaken for all proposed REDD+ schemes to ensure they are economically viable before they are authorised. Involving local people in monitoring work can reduce the costs considerably - with the added advantage of increasing their commitment. International agencies (e.g. the World Agroforestry Centre) 
have developed toolkits for participatory carbon assessment and have undertaken pilot projects in several countries. However, the application of these toolkits is still limited, partly because of lack of funds but also because government staff do not believe that local people have sufficient capacity to carry out the related tasks, which require accuracy and technical skills.

It is important that REDD+ uses existing mechanisms for monitoring in order to reduce transaction costs and strengthens enforcement by making full use of existing government rules and personnel. Involving local communities in relevant and appropriate monitoring activities can also help to reduce transaction costs. In this context also, the core issue is 'the state of mind' rather than the costs themselves.

\subsection{Institutional arrangements, coordination and commitment}

The fact that Vietnam has a REDD+ coordinating agency - VNFOREST - and an established REDD+ Working Group, with domestic and international partners, clearly reflects the importance given to sovereignty in the implementation of REDD+ in Vietnam; it also shows Vietnam's commitment to implementing REDD+ and enhances trust among donors for REDD+ development in the country.

Despite such progress, however, current institutional arrangements reveal some limitations that might impede the success of new initiatives. First, managing the large sums provided by donors to implement and pilot REDD+ is a significant challenge for local governments. Without accountable and transparent financial procedures, there is a strong likelihood that the money will not be spent appropriately. In addition, the limited number of staff within MARD, which is the leading agency responsible for REDD+ in Vietnam, has delayed the process of implementation to some extent. Second, although the National REDD+ Programme acknowledges the importance of involving all stakeholders, some key parties are not being consulted and engaged in its development. The coordination between central and local levels follows the MARD hierarchy management model, with which local authorities and communities are familiar. Local authorities in provinces undertaking REDD+ pilot projects have received both financial and technical assistance from central ministries. These authorities have been consulted from the initial development of projects through to the final decision to implement initiatives. However, their limited understanding of the issues restricts their influence.

\subsection{Equity}

The government and donors have established different avenues for stakeholders to contribute their ideas to REDD+. At the national level, technical workshops and forums (REDD+ Network and FSSP) provide an arena for the government to share information and consult with stakeholders on REDD+ design. However, this mechanism has not promoted active participation among stakeholders because of the restricted time available for discussion and the minimal scope for these stakeholders to influence the debate.

At the local level, the government has issued a number of policies on decentralising management and decision-making power. For example, the Ordinance on Grassroots Democracy provides a legal mechanism for people to comment on draft policies and programmes. In theory, these policies should empower local authorities and people to take responsibility for land use planning. However, the top-down approach and the fact that local people are not aware of these policies or their rights render this meaningless. In addition, decisions are often made at the central level and consultations with local authorities and people are just a formality. Lack of information and understanding about REDD+ means that local authorities are dependent on specific directions from the central government and cannot address problems actively and independently.

A successful REDD+ scheme requires the active participation of all related stakeholders, including sellers, buyers and intermediaries. However, donors and government agencies tend to dominate most schemes, and representatives of the poorer providers of environmental services are often absent. This creates a bias in REDD+ design and potential elite capture of benefits within communities. Future REDD+ design will need to consider different channels for the poor, women and indigenous groups and their representatives, 
to participate in and monitor the schemes. In addition, although government policies on forest protection and development encourage private sector participation and engagement, the participation of the private sector in the implementation of REDD+ is limited. Some international companies are involved in developing REDD+ projects and providing technical assistance (mainly professional consulting firms), but the role of the domestic private sector is limited. Similarly, the role of CSOs is limited, mainly because of centralised governance and their limited capacity to influence the REDD+ arena. CSOs are usually invited to REDD+ meetings and their voices have been heard, but with minimal impact. Future structures should consider a formal role for these organisations, some of which have strong technical capacity and experience of working with vulnerable communities. CSOs can provide valuable input into REDD+ design as well as onthe-ground implementation. The current local civil society networks are already in place and, if strengthened, can provide an efficient link to government structures.

The issue of gender equity has so far received little serious attention. This can be traced to the fact, as revealed through the interviews, that there is a lack of recognition of gender equity in the current curriculum of natural resources, forestry and agroforestry education and training systems. Neither has the issue of intergenerational inequity been much discussed in relation to REDD+. A representative of a CSO interviewed claimed that a youth group has been actively engaged in the climate change arena and discussion on REDD+ in different forms (e.g. learning platform and initiatives, working groups, etc.), but that other social groups do not perceive youth groups as serious agents of change. The needs and concerns of young people - future leaders - both in urban and in rural areas - have not been analysed, even though this can be a potential driver of or solution to deforestation and degradation.

Lessons from implementation of the National Targeted Program 135 Phrase II (a five-year national poverty reduction programme, 20062010) indicate that the limited participation in national programmes arises for two main reasons. First, villagers are often simply informed about rather than involved in their own development.
Second, subnational governments may view 'participation' in planning only as a requirement for donor projects rather than as a useful tool; therefore, it does not continue when a donor project ends or is not transferred to other government projects (Jones et al. 2008). The government and donors should make sure that current requirements for participation and transparency are fulfilled and that local governments see them as necessary tools for achieving their own objectives rather than as rules imposed upon them. To achieve this, Jones et al. (2008) calls for more detailed guidance on 1) the stage at which local people should be involved in discussions; 2) the timing and manner in which they should be informed about the final plan; 3) the timing for when they should be informed about the approved plan; and 4) the number of people and level of male and female participation in planning meetings, as a way of ensuring comprehensive and gender-sensitive planning.

As mentioned, Vietnam's national economic growth did not equally benefit all 54 officially recognised ethnic groups in Vietnam; rather, the Kinh group has received preferential treatment (Jones et al. 2008). More recently, however, the rights of indigenous people have received increasing attention from the international community and the Vietnamese government. The government has signed numerous international treaties and instituted policies on indigenous rights. It has also formed a number of national institutions aimed at ensuring indigenous people's rights to use forest resources, such as the Committee for Ethnic Minorities and Mountainous Areas. However, the involvement of indigenous people in REDD+ remains limited because of language barriers, low education levels and limited negotiating ability for benefit sharing.

Establishing appropriate payments for REDD+ is essential. The current level of REDD+ payment is not based on an accurate assessment of the opportunity costs, but rather is decided by the available budget and donor estimates. In areas where people do not live in the forest or where forest resources are degraded - meaning opportunity costs are low - people are willing to accept this level of payment. However, in areas where people rely heavily on the forest or the opportunity costs are higher, REDD+ will be 
difficult to implement if it provides little incentive to reduce deforestation and forest degradation. Furthermore, forestry regulations are too often implemented in different ways in different provinces. Some provinces are more flexible and progressive than others and can set up trial sites for community forestry before the central government legally acknowledges this form of forest management. 


\section{Conclusions and recommendations}

$\mathrm{T}$ This report started by examining the forestry sector in Vietnam, deforestation rates and drivers of deforestation. Vietnam stands out as having achieved a net increase in forest cover in recent years, thus having entered Phase 4 of the forest transition. This increase is largely due to expansion of plantations as well as re-categorisation of existing forests and natural regeneration $(\mathrm{Vu}$ et al. 2011); it has also been driven by forest tenure reform, new technologies and market liberalisation (Sikor 2001). Vietnam is also notable for its concerted reform efforts. The opening of the economy has had far-reaching impacts. In particular in the context of REDD+, it has driven the production of export commodities such as coffee, rubber and wood products, which have led to increased deforestation. This effect has been somewhat balanced through reforms within the forestry sector, including FLA, the restructuring of SFEs and reforestation efforts.

Overall, however, although the forest area in Vietnam has increased, the quality of forests has declined. With regard to future REDD+ options, the carbon content of much of Vietnam's forests might be lower than that of natural forests, which continue to be under threat. Two basic causes of this threat stand out: (1) land conversion for agricultural crops and infrastructure development and (2) unsustainable logging. Both are driven by economic development and policies targeting such development, mainly through exports. Other policies affecting these factors are those that give preferential treatment to industries of national interest, such as the pulp and paper industry and hydropower plants, although these industries are, in reality, economically unsustainable.

The underlying causes of deforestation are poor governance, corruption and poor coordination among ministries. Forest governance has been decentralised to the lowest level and use rights over forest devolved to stakeholders outside the forest bureaucracy: private companies, communities, households and individuals. However, the final decision over forest allocation and use still rests with the government. FLA provides basic rights to use forest and reap its benefits. However, allocation has not been equitable, with better-off and betterinformed farmers gaining the better and larger pieces of land. State agencies continue to manage the largest area with households and individuals combined controlling less than $30 \%$.

This situation persists partly because of weak capacity, that is, not all stakeholders are sufficiently informed of their roles, rights and duties. It is also partly due to corruption wasting significant resources and leading to inefficient and ineffective efforts. If these issues are not addressed adequately, the new policies and international agreements on REDD+ might not be implemented effectively.

Vietnam has shown great interest in climate change mitigation and REDD+, and has been involved in all related international discussions. In general, current policies in Vietnam provide a good platform for REDD+ to develop, and REDD+ can potentially contribute significantly in implementing deforestation and forest 
degradation initiatives. However, these policies and programmes are still hampered by significant limitations, including low participation of poor environmental service providers and the private sector, inconsistent data, ineffective benefitsharing mechanisms, high transaction costs for REDD+ implementation and a centralised budget. Thanks to a high level of commitment from the government and increasing support from international and national agencies, these limitations can be transformed into valuable lessons to guide future implementation. The REDD+ pathway is paved with challenges but capacity building for all stakeholders and refining of REDD+-related policies will help enable effective, efficient and equitable REDD+ implementation in Vietnam. Good governance and effective monitoring systems also require better information sharing and coordination among government agencies and among stakeholders. More specifically, in order to implement REDD+, some issues need to be resolved. The government needs to take greater ownership of REDD+ programmes. Although the Vietnamese government is committed and has developed multiple policies, most programmes are implemented only because of international support.

All stakeholders, including both those in other sectors and members of the public, need to be informed and develop skills for implementing REDD+. Currently, REDD+ is only discussed by scientists and forestry officials. Officials from other sectors might be aware of the issue but few are directly involved. At lower levels and even less at the community level, REDD+ is practically unknown. Thus, there is a need to improve extension services by increasing funding and personnel, restructuring the system and improving coordination, and in the process empowering local people. A goal of REDD+ is to benefit forestdependent communities. In Vietnam, it is to be integrated into the framework for PES. This implies that in the long term, domestic users of the environmental services are expected to pay for that use, which would ensure sustainability of the scheme. However, also necessary are the careful crafting of policies, proper implementation mechanisms, appropriate participation options and more transparent and equitable benefit-sharing mechanisms. In this regard, more attention must be given to integrating local knowledge and traditions into these programmes.

However, some practical lessons from PES reveal aspects that should be reconsidered in REDD+ design. First, PES is not voluntary. Environmental services buyers are forced to pay, which reduces their willingness and compliance. Second, the $\mathrm{K}$ coefficient in the PES formula is difficult to quantify so $\mathrm{K}$ is set equal to 1 , and everyone is paid at the same rate. This leads to inequity among communities where efforts made for forest protection differ.

Furthermore, informal systems should be accepted and used to support formal systems. In cases where formal and informal systems come into conflict, the government must take an appropriate mediating role. Importantly, there is no 'one-size-fits-all' approach to REDD+ at the community level; rather, the implementation of individual programmes must consider local needs and customs.

Forest tenure reform will be an asset in future REDD+ programmes. However, further reforms are needed to overcome the problem of high transaction costs for monitoring the fragmented holdings; many holdings are simply too small to make a difference for climate change on the one hand and income for owners on the other hand. One option is to improve cooperation among individuals or even communities and villages. This approach would incur high initial transaction costs and complexity in involving many individual villages, but a cooperative established among multiple villages could then be examined as a potential structure for coordinating and monitoring REDD+, as well as functioning as a financial conduit. Such cooperatives would have legal status and therefore be able to negotiate, contact buyers, sign contracts and receive payments on behalf of the community.

REDD+ in Vietnam needs to be placed within an integrated land use plan to be managed both at the macro level by the state and at the micro level by local communities. Implicit is the need to improve monitoring mechanisms and integrate community 
monitoring within the overall monitoring system. Another option to improve monitoring is to invite the participation of a third or independent party.

Finally, Vietnam has the same needs as many other potential REDD+ countries, with issues arising that remain unsolved but are a prerequisite for REDD+ implementation: better law enforcement, coordination, communication, information dissemination, transparency and accountability. 


\section{References}

Abonyi, G. 2002 Toward a Political Economy Approach to Policy-based Lending, ERD Working paper series No. 14 Economics and Research Department, Asian Development Bank.

Angelsen, A. (ed.) 2008 Moving ahead with REDD: issues, options and implications. CIFOR, Bogor, Indonesia.

Apel, U. 2000 Forest protection regulations as a precondition for natural regeneration in the Song Da watershed, Northwest Vietnam. European Commission, Hanoi, Vietnam.

Artemiev, I. 2003 State forestry enterprise reform in Vietnam. Unlocking the potential for commercial wood growing. Technical Note EASRD. Rural Development and Natural Resources East Asia and Pacific Region, World Bank, Hanoi, Vietnam.

Asian Development Bank 2001 Poverty Alleviation in Credit, Forestry and Sedentarization Programs. Sedentarization and Poverty Reduction Project. Hanoi, Vietnam: Asian Development Bank.

Asian Development Bank (ADB) 2000 Study on the policy and institutional framework for forest resources management. Asian Development Bank. TA No. 3255 - VIE. Agriconsulting S.P.A., Rome, Italy, and Hanoi, Vietnam.

Australian Agency for International Development (AusAID) 2000 Vietnam land administration. Working paper No 4. Australian Agency for International Development. Avaiable at: http://www.ausaid.gov.au/publications/pdf/ vietnam_wp4.pdf [2 February 2012].
Bleaney, A., Vickers, B. and Peskett, L. 2009 What could REDD look like in Vietnam? Avaiable at: http://redd-net.org/files/ What couldREDDlooklikeinvietnam.pdf [7 August 2011].

Boissiere, M., Sheil, D., Basuki, I., Wan, M. and Le, H. 2009 Can engaging local people's interests reduce forest degradation in Central Vietnam? Biodiversity and Conservation 18: 2743-2757.

Brockhaus, M.; Di Gregorio, M.; WertzKanounnikoff, S. 2010 - Country Profile, unpublished project document, Center for International Forestry Research, Bogor, Indonesia.

Bui, D.T., Dang, T.H. and Nguyen, Q.C. 2004 Rewarding upland farmers for environmental services: experience, constraints and potential in Vietnam. World Agroforestry Centre, Bogor, Indonesia.

Carew-Reid, J., Poynton, S., Chu., T.T., Dubois Q., Halle, M., Larsen,T., Le, D.T., Le, T.C., Nguyen, M.T., O'Rouke, D. and Vu, X.N.H. 1999 A Study on Aid to The Environment Sector in Vietnam. Ministry of Planning and Development and United Nations Development Programme. Hanoi, Vietnam.

Castrén, T. 1999 Timber trade and wood flow study, Vietnam. Regional Environmental Technical Assistance 5771. Poverty Reduction and Environmental Management in Remote Greater Mekong Subregion (GMS) Watersheds (Project Phase 1). Asian Development Bank, Manila, Philippines. 
Central Institute for Economic Management (CIEM) 2010 Policy analysis for the evaluation of Vietnam's 2-year WTO accession. Ministry of Planning and Investment, Hanoi, Vietnam.

Centre for Natural Resources and Environmental Studies (CITES) Scientific Authority of Vietnam 2008 Report on the review of Vietnam's wildlife trade policy. Centre for Natural Resources and Environmental Studies, Vietnam National University, Hanoi, Vietnam.

Chinh, C. 2010 Corruption in land field: the octopus. An Ninh Thu Do, 28 November 2007.

Chu, T.T.H., and Dickie, P.M. 2006 Economic transition in Viet Nam: Doi Moi to WTO. PPTP Studies Series 1/2006. Public Policy Training Program. Asian Development Bank, Hanoi, Vietnam.

Consultative Institute for Socio-Economic Development of Rural and Mountainous Areas (CISDOMA) 2009 Development of a new sustainable forest management planning methodology. Avaiable at: http://www. vietnamforestry.org.vn/LinkedFiles/NFP/ CIDOMA/a-iii-\%20The\%20methodologyVn\%20with\%20summary-En.pdf [2 February 2012].

Costenbader, J. 2011 REDD+ benefit sharing: a comparative assessment of three national policy approaches. UN-REDD and Forest Carbon Partnership Facility. Avaiable at: http://reddpluspartnership.org/29783-02f9 f945a76791c4c62a665cbf864296d.pdf [2 February 2012].

de Jong, W., Do, D.S. and Trieu, V.H. 2006 Forest rehabilitation in Vietnam: histories, realities and future. CIFOR, Bogor, Indonesia.

Delang, O.C. 2005 The market for medicinal plants in Sapa and Hanoi, Vietnam. Economic Botany 59: 377-385.

Department of Forest Protection (DoFP) 2010 Data of changes in the forest of Vietnam from 2002 to 2009. Avaiable at: http://www. kiemlam.org.vn/Desktop.aspx/News/So-lieudien-bien-rung-hang-nam/ [7 August 2011].

Deringer, F.B. 2007 Infrastructure development in Vietnam. Avaiable at: http://www.freshfields. com/publications/pdfs/2007/july23/19219. pdf [2 February 2012].
Dinh, D.T. 2005 Forestry, poverty reduction and rural livelihoods in Vietnam. Ministry of Agriculture and Rural Development. Hanoi, Vietnam.

Dixon, C. 2000 State versus Capital: The Regulation of the Vietnamese Foreign Sector. Singapore Journal of Tropical Geography 21(3): 279-294.

Do, D.S. and Le, Q.T. 2001 Forest policy trends in Vietnam. Policy Trend Report 2001: 69-73.

Do, Q.T., and Iyer, L. 2008 Land titling and rural transition in Vietnam. Economic Development and Cultural Change 56(3): 531-79.

Doan, D. 1998 Forestland allocation and incentives for forest plantations. A paper at the National Workshop on "Chu Rung va Loi Ich Trong Kinh Doanh Trong Rung" (Forest Owners and Benefits in Forest Plantations). Ministry of Agriculture and Rural Development. Hanoi, Vietnam.

Doan, D. 2009 Assessment of options for reducing emission from land uses in Vietnam: forest and forestry land. Interim report to the World Agroforestry Centre in Vietnam. Hanoi, Vietnam.

Doan, D., Shanks, E. and Nguyen, T.B. 2005 Situation analysis, needs assessment and recommendations of forestry research, education, training and extension (RETE) for the National Forestry Strategy 2006 to 2020. Helvetas International and Ministry of Agriculture and Rural Development. Hanoi, Vietnam.

Dollar, D. and Ljunggren, B. 1997 'Vietnam', in Going Global. Padma Desai, ed.Cambridge, Mass.: MIT Press, pp. 439-71.

Donovan, D., Rambo, T.A., Fox, J., Le, T.C. and Tran, D.V. (eds.). 1997 Development trends in Vietnam's northern mountain region. Volume 2: Case studies and lessons from Asia, 51-63. National Political Publishing House, Hanoi, Vietnam.

Duc, T. 2005 Poverty reduction and rural livelihoods in Vietnam. Forest Sector Support Programme and Partnership, Ministry of Agriculture and Rural Development. Hanoi, Vietnam.

Dutt, P., Avrane, H, Solimene M, Nothelfer, D. 2004 Vietnam's transition to a market economy: Assessment and recommendations: Key lessons from East Germany, Russia 
and China Economics and Management in Developing Countries, The Business School for the World (INSEAD), Rajah Avenue, Singapore.

EASRD 2005 State forest enterprise reform in Vietnam. Avaiable at: http://siteresources. worldbank.org/INTVIETNAM/Resources/ vn_sfe_report_en.pdf [2 February 2012].

Energy and Environment Consultancy Joint Stock Company (VNEEC) 2010 Report assessment of CDM potential in Viet Nam and database. Embassy of Denmark in Hanoi, Vietnam.

FAO 2010 Global Forest Resources Assessment 2010 - Vietnam Country Report. Available at: www.fao.org/docrep/013/al664E/al664e. pdf [10 February 2012].

Farley \& Williams 2009 Infrastructure development in Vietnam. Available at: http://www.wfw.com/website/wfwwebsite. nsf/Publications/Publication553. html/\$File/WFW\%20Infrasstructure $\% 20$ Development\%20in\%20Vietnam\%20update. pdf [2 February 2012].

Fforde, A. 2000 The Political Economy of "PostTransition" Vietnam. Shorenstein APARC Southeast Asia Forum. Available at: http:// fsi.stanford.edu/ events/the_political_ economy_of_posttransition_vietnam [12 December 2011].

Fforde, A. 2004 Vietnam: what needs to be done?. $\mathrm{n}$ J. Rolfe (Ed.). The Asia-Pacific: A Region in Transition (pp. 285-299): Honolulu: AsiaPacific Center for Security Studies. Avaiable at: http://www.apcss.org/ Publications/Edited\% 20Volumes/RegionalFinal\% 20chapters/ Chapter17Fforde.pdf [12 December 2011].

Fforde, A. 2008 Economic transformation: some implications of Vietnam's economic growth pattern Or Reflections on the economics of Vietnamese capitalism and possible political implications. Paper presented at Conference "Remaking the Vietnamese State: Implications for Viet Nam \& Beyond”. August 2008, City University of Hong Kong. Avaiable at; http://www.aduki.com.au/Economics $\% 20$ in $\% 20$ command $\% 20$ for $\% 20$ website.pdf [12 December 2011].

Forest Carbon Partnership Facility (FCPF) 2010 Vietnam R-PP. Available at: www. forestcarbonpartnership. org/.../3e.\%20PC_ review_R-PP_... [12 May 2011].
Forest Sector Management Information System (FORMIS) 2005 Viet Nam forest sector indicators and 2005 baseline data report. Forest Sector Support Programme, Ministry of Agriculture and Rural Development. Hanoi, Vietnam.

Forest Trends 2010 Timber Markets and Trade Between Laos and Vietnam: A Commodity Chain Analysis of Vietnamese-Driven Timber Flows. US.

Forsberg, L.T. 2007 Defining Strong Ownership: Institutional Determinants and Stakeholder Interests in Vietnamese Development Planning. Doctoral Thesis, Stockholm:Almqvist \& Wiksell International Publisher.

Forsberg, L.T. 2011 The Political economy of Health Care Reform in Vietnam. Oxford - Princeton Global Leaders Fellow Woodrow Wilson School of Public and International Affairs Princeton University, Oxford University. Available at: http://www. princeton. edu/ $\sim$ pcglobal/conferences/GLF/ forsberg_glf.pdf [15 December 2011].

Fritzen, A.S. 2006 Probing system limits: decentralisation and local political accountability in Vietnam. The Asia Pacific Journal of Public Administration 28(1): 1-23.

General Statistical Office (GSO) 2000 Statistical Yearbooks 1975-2000. General Statistical Office (GSO). Ha noi, Vietnam. Vietnamese Language.

Global Compact and Vietnam Chamber of Commerce and Industry (VCCI) 2010 A review of the social and environmental conditions of industries $\mathrm{n}$ Vietnam against the global compact principles. Available at: http:// www.globalcompactvietnam.org/upload/ attach/GCNV\%20Research\%201.pdf

Government Statistics Office (GSO) 2009 The year book of 2008. General Statistical Office (GSO), Hanoi, Vietnam.

Government Statistics Office (GSO) 2010 The year books of 2008, 2009, 2010.General Statistical Office (GSO), Hanoi, Vietnam.

Hawkins, S., To, X.P., Pham, X.P., Pham, T.T., Nguyen, D.T., Chu, V.C., Brown, S., Dart. P., Robertson, S. Vu, N. and McNally, R. 2010 Roots in the water: legal frameworks for mangrove PES in Vietnam. Katoomba Group's 
Legal Initiative Country Study Series. Forest Trends, Washington, DC.

Helvetas Vietnam 2002 Vietnam experience \& possible contribution to SDC development goal: Sustainable livelihoods \& poverty reduction in the uplands. Helvetas Vietnam. Hanoi, Vietnam.

Hirsch, P., Bach, T.S., Nguyen, N.H.V., Do, T.H., Nguyen, Q.H., Tran, N.N., Nguyen, V.T. and $\mathrm{Vu}$, Q.T. 1992 Social and environmental implications of resource development in Vietnam: the case of Hoa Binh Reservoir. RIAP Occasional Paper No. 17. University of Sydney, Sydney, Australia.

Hoai, N. 2010 Forest protection - one person protects the forests, thousands people destroyed the forest. Ministry of Agriculture and Rural Development. Hanoi, Vietnam. Avaiable at: http://dof.mard.gov.vn [7 August 2011].

Hoang, M.H., Pham, T.T., Do, T.H. and Thomas, D. 2010 An assessment of options for reducing emissions from all land uses in Vietnam ready for REDD. World Agroforestry Centre (ICRAF), Hanoi, Vietnam.

Hoang, T.D. 2006 Gender issues in the forestry sector in Vietnam. Ministry of Agriculture and Rural Development Hanoi, Vietnam.

Hobley, M., Ram, S. and Bergman. A. 1998 From Protection to Protection through Production: A process for forest planning and management in Ha Giang and Yen Bai provinces. Draft report.

Holland, T. \& McNally, R. 2010 REDD Working Papers: REDD and sustainable development - perspective from Viet Nam. International Institute for Environment and Development (IIED). London.

Huynh, T.B. 1998 Human Migration and Resource Utilization. WWF Indochina Program. Vietnam.

International Center for Environmental Management (ICEM) 2003 Vietnam national report on protected areas and development. Review of protected areas and development in the lower Mekong River region. ICEM, Indooroopilly, Queensland, Australia.

Javier, H., Le, D.T., Mireille, R., François, R., Pham, T.H. 2008 Analysis of the P135-II Baseline Survey. Support to the Improvement and Implementation of the National Targeted Programs on Poverty Reduction. Component:
Support to the SEDEMA/135 Program Implementing agency, State Committee of Ethnic Minority Affairs (CEMA), PROJECT VIE/02/001.

Jones, R., Nguyen, T.T.H. and Tran, T.A. 2008

Keynote paper: supporting the mid-term review of the National Targeted Programme 135 second Phase (P135II). Study on Planning and Resource Allocation in P135II, Don Taylor \& Associates, Duval County, US.

Lai, T.Q. and Vij, S. 2010 Reducing conflict through co-management: lessons learned from Tram Chim National Park, Vietnam. The Center for People and Forests (RECOFTC). Hanoi, Vietnam.

Lang, C. 2002 The Pulp Invasion: The international pulp and paper industry in the Mekong Region. World Rainforest Movement. Uruguay.

Le, D.N. 1998 Forest owners: increasing benefits for forest owners, perspectives from private forest plantation enterprises. Paper presented at the National Workshop on "Chu Rung va Loi Ich Trong Kinh Doanh Trong Rung" (Forest Owners and Benefits in Forest Plantations)Ministry of Agriculture and Rural Development. Hanoi, Vietnam.

Le, K.C. 2010 Process of analysis, construction, implementation. M\&E National Forest Program. Ministry of Agriculture and Rural Development Hanoi, Vietnam.

Le, K.C. 2010 Vietnam national forest programme process evaluation report ( $2 \mathrm{nd}$ draft). Available at: http://vietnamforestry.org.vn/ NewsFolder/ NFP\%20Assessment\% 20Report_EN.pdf [2 February 2012].

Le, T.C. 2003 Uplands of Vietnam. In: Jianchu, X. and Mikesell, S. (eds.) Landscapes of diversity: indigenous knowledge, sustainable livelihoods and resource governance in montane mainland Southeast Asia. Proceedings of the III Symposium on MMSEA 25-28 August 2002, Lijiang, P.R. China, 113-119. Yunnan Science and Technology Press, Kunming, China.

Le, T.C., Dang, T.T., and Tran, Y. 1993 EIA of Bai Bang Pulp and Paper factory. EIA Unit, National Research Programme on Environment. Hanoi, Vietnam.

Le, T.H. 2009 Vietnam's forest is decreasing. Available at: http://www. taybacuniversity. edu.vn/fhg/index. php?view=article\&id=255\%3Arung- 
viet-nam-xua-va-nay\&option=com content\&Itemid=101. [5 January 2012].

Leonard, K.D. 2004 The Political Economy of International Development and Pro-Poor LivestockPolicies: A Comparative Assessment. Working Paper No. 12. ILRI. Pro-poor Livestock Policy Initiative (PPLPI)

Markopoulos, M. 2009 Changing international markets for wood products: how is Viet Nam Responding? Forest Governance Officer, Asia Regional Office (ARO), China and the Global Forest Products Trade: Trade of Legal and Sustainable Wood in China. Beijing, China, 21-22 April 2009.

Markussen, T., and Tarp, F. 2011 Political Connections and Investment in Rural Vietnam. Working Paper No. 2011/37, UNU World Institute for Development Economics Research (UNU-WIDER). Katajanokanlaituri 6 B, 00160 Helsinki, Finland.

McElwee, P. 2001 Fuelwood Harvesting and Use in Cam Xuyen District, Ha Tinh Province. Forest Science Institute of Vietnam, NonTimber Forest Products Research Center. Hanoi, Vietnam

McNally, R., Sage, N. and Holland, T. 2009 Understanding REDD Implications for lao PDR, Nepal and Vietnam. Netherlands Development Organisation (SNV). Vietnam.

Merckx, V. 2011 Addressing illegal logging and trade: FLEGT linkages with REDD+. Oslo REDD Exchange, 23 June 2011. European Forest Institute - FLEGT/REDD Unit.

Meyfroidt, P. and Lambin, E.F. 2008 Forest transition in Vietnam and its environmental impacts. Global Change Biology 14: 1319-1336. doi: 10.1111/j.13652486.2008.01575.x.

Ministry of Agriculture and Rural Development (MARD) 2007a Feasibility report. Project on forest development to improve the livelihood in Tay Nguyen. MARD. Hanoi, Vietnam.

Ministry of Agriculture and Rural Development (MARD) 2007b Project of forest allocation and lease for the period of 2007-2010. [Attached to Decision No. 2740 /QĐ- BNNKL.] MARD. Hanoi, Vietnam. Ministry of Agriculture and Rural Development (MARD). 2007c Project 'Support to the people in the high land in sustainable farming on the steep land areas' for the period of 2008-2021. [Attached to Decision No 2945/
QĐ-BNN-KL, 5 October 2007.] MARD. Hanoi, Vietnam.

Ministry of Agriculture and Rural Development (MARD) 2007d Vietnam forest development strategy, 2006-2010, Vietnam. MARD, Hanoi, Vietnam.

Ministry of Agriculture and Rural Development (MARD) 2009 Action plan of agricultural and rural sector to adapt to and mitigate the impact of climate change. MARD, Hanoi, Vietnam.

Ministry of Agriculture and Rural Development (MARD) 2010 The outcomes of the implementation of project on 'Growing 5 million ha of forest in 2009 and plan, task of 2010'. MARD, Hanoi, Vietnam.

Ministry of Labor and Social Affairs (MOLISA) 2010 The Social Security Strategy for 2010 - 2020, $6^{\text {th }}$ Draft, Hanoi October 2010. 6th Draft of the Social Security Strategy for 2010-2020. Ministry of Labor and Social Affairs, Hanoi October 2010.

Ministry of Natural Resources and Environment (MONRE) 2006 Report on environmental status of Vietnam. MONRE, Hanoi, Vietnam.

Ministry of Natural Resources and Environment (MONRE) 2008 The fourth country report on Vietnam's implementation of the biodiversity convention. Report to the Biodiversity Convention Secretariat. MONRE, Hanoi, Vietnam.

Morrison, E. and Dubois, O. 1998 Sustainable livelihoods in upland Vietnam: land allocation and beyond. IIED Forestry and Land Use Series No 14. International Institute for Environment and Development. London. Müller, D., Epprecht, M. and Sunderlin, D.W. 2006 Where are the poor and where are the trees? Targeting of poverty reduction and forest conservation in Vietnam, Working Paper No. 34. CIFOR, Bogor, Indonesia.

Neumann, R.P. and Hirsch, E. 2000 Commercialisation of non-timber forest products: review and analysis of research. CIFOR, Bogor, Indonesia.

Ngo, T.M.H. 1996 A cost-benefit analysis of smallholder investments in reforestation. National Economic University. Project 1 VIE 62.9. Swedish International Development Cooperation Agency (SIDA). Hanoi, Vietnam. Nguyen, D.T và Đinh, T.M. 2011 Kinh tế Việt Nam trong bối cảnh kinh tế thế giới hiện nay 
- một số phân tích và khuyến nghị chính sách

(Vietnam economy in current world: Analysis and policy recommendations), National University, Hanoi, Vietnam.

Nguyen, N.B. 2010 Report of sustainable forest management and development achievement, shortcomings and solutions. Presented at the Annual Forest Partnership (FSSP) meeting,, Hanoi, Vietnam, 2 February 2011.

Nguyen, N.L. 2001 Report on study on community forestry and community forestry policy in the northwest areas. Ministry of Agriculture and Rural Development and GTZ, Hanoi, Vietnam.

Nguyen, Q. and Kammeier, D.H. 2002 Changes in the political economy of Vietnam and their impacts on the built environment of Hanoi. Cities 19 (6): 373-388.

Nguyen, Q.T. 2005 Re-inventing forestry agencies: institutional restructuring of forestry agencies in Viet Nam since 1994. Available at: http:// www.fao.org/docrep/010/ai412e/AI412E05. htm [2 February 2012].

Nguyen, Q.T. 2008 The household economy and decentralization of forest management in Vietnam. In: Lessons from forest decentralization, Money, Justice and the Quest for Good Governance in Asia-Pacific, (Eds) Colfer PJC, Dahal GR and Capistrano D. page 185-277, Earthscan London, UK.

Nguyen, Q.T, Nguyen, B.N. and Nguyen, N.T 2008 Forest tenure reform in Vietnam: case studies from the northern upland and central highlands regions. The Center for People and Forests (RECOFTC) and the Rights and Resources Initiative (RRI). Hanoi, Vietnam.

Nguyen, Q.T., Sikor, T., Vickers, B. and Enters, T. 2010 Vietnam: why REDD+ needs local people. Briefing note. RECOFTC Bangkok, Thailand.

Nguyen, T.H., Phan, K.L., Nguyen, D.T., Luu, P.I., Farjon, A.T., Averyanov, L. and Regalado, J. 2004 Vietnam conifers: conservation status review 2004. Fauna \& Flora International, Vietnam Program, Hanoi, Vietnam.

Nguyen, T.Q và Tran, H.N. 2011 How Vietnam is prepared to meet legal requirements of timber export markets, Tropenbos International Vietnam, Hue City, Vietnam.

Nguyen, V.D.S. 2008 The Political Economy of Hydropower Dam Construction in Vietnam. Available at: http://www.stimson. org/essays/the-political-economy-ofhydropower-dam-construction-in-vietnam/ [10 December 2011].

Nguyen, V.S. and Gilmour, D. 1999 Forest rehabilitation policy and practice in Vietnam. International Union for Conservation of Nature (IUCN), Hanoi, Vietnam.

Ogle A.J., Blakeney, K.J. and Hoang L. 1999 Evaluation of state forest enterprises. Final report. Asian Development Bank (ADB) Forestry Sector Project, Hanoi, Vietnam. Paper Index Times 2009 Vietnam's plantation resources: an important supply source for pulpmills in Japan and China: WRQ. Available at: http://news.paperindex. com/Business_Economy/Vietnamrsquos_ Plantation_Resources_an_Important_Supply_ Source_for_Pulpmills_in_Japan_and_China_ WRQ/ [9 July 2011].

Pham, D. T. 1999 Bao cao Nghien cuu ve Thuc trang Kinh te Xa hoi cua Mot xa Vung cao va Mot xa Vung thap tai Mien nui phia Bac. (A Comparative Study of the Socio-economic Situations of a Lowland Commune and an Upland Commune in the Northern Mountains.) Hanoi Agricultural University. Hanoi, Vietnam.

Pham, M.C. 2009 Vietnam's experience towards REDD readiness and country initiatives. Available at: http://www. rainforestcoalition.org/TinyMceFiles/2009presentations/Bonn $\% 20$ August $\% 2015 \% 20$ 2009\%20Vietnam\%20Presentation.pdf [2 February 2012]

Pham, Q.D. và Nguyen, Q.C. 2009 Dấu hiệu phục hồi cho ngành gỗ. Thời báo Kinh tế Sài gòn Online (Wood Recovery/Sai Gon Times). Available at: http://www.thesaigontimes. vn/ Home/vanhoa/tanvan/25057/ [20 February 2012].

Pham, T.T., Campbell, B.M., Garnett, S., Aslin, H. and Hoang, M.H. 2010 Importance and impacts of intermediary boundary organisations in facilitating payment for environmental services in Vietnam. Environmental Conservation 37: 64-72.

Pham, T.T., Campbell, M.B. and Garnett, S. 2009 Lessons for pro-poor payment for environmental services: an analysis of the payment for environmental services projects in Vietnam. Asian Pacific Journal of Public Administration 31: 117-135. 
Pham, T.T., Garnett, S. and Aslin, H. 2011

Organisational and institutional opportunities for, and constraints to, involvement of poor households in payments for environmental services in Vietnam. Journal of Asian Pacific Public Administration and Development, 33(1): 57-76.

Poffenberger, M. and Nguyen H.P. 1998

The national forest sector. Part 1. In: Poffenberger, M. (ed.) Stewards of Vietnam's Upland Forests. Research Network Report Number 10. Asian Forestry Network. www. communityforestryinternational.org.

ProForest 2009 Joint FLEGT Vietnam scoping study - main report prepared for the European Forest Institute (EFI) final report. Joensuu, Finland.

Raintree, J.B., Le, T.P. and Nguyen, V.D. 1999 Report on a diagnostic survey of conservation problems and development opportunities in Khang Ninh Commune in the buffer zone of Ba Be National Park. Project on Sustainable Utilization of Non-Timber Forest Products. Forest Science Institute of Vietnam, Hanoi, Vietnam.

Rambo T, Le TC. 1996 Rural Development Issues in the Upland Agroecosystems of Vinh Phu Province. In Red Book, Green Hills, The impact of Economic Reform on Restoration Ecology in the Midlands of Northern Vietnam. (co-editors: Le TC, Rambo, T, Fahrney K, Tran DV, Romm, J, Dang TS. East-West Center, Honolulu. 127pp.

RECOFTC 2011 Vietnam's forestry reforms. http://www.recoftc.org/site/Vietnam-sForestry-Reforms [8 July 2011].

RECOFTC and ASFN 2010 The Role of Social Forestry in Climate Change Mitigation and Adaptation in the ASEAN Region, RECOFTC, ASFN, and SDC Bangkok, Thailand.

RECOFTC, ASFN and SDC 2011 The role of social forestry in climate change mitigation and adaptation in the ASEAN Region. Assessment 2010. ASFN, SDC and RECOFTC, Bangkok, Thailand.

Sai Gon Times 2009 Improper infrastructure poses biggest threat to forests, biodiversity. Available at: http://english.thesaigontimes.vn/Home/ business/other/4951/ [4 February 2012].

Scheyvens, H. 2010 Developing national ReDDplus systems: Progress challenges and ways forward Indonesia and Viet nam country studies, Institute for Global Environmental Strategies (IGES), Kanagawa, Japan

Sikor, T. 1998 Forest policy reform: from state to household forestry. In: Poffenberger, M. (ed.) Stewards of Vietnam's Upland Forests. Research Network Report Number 10. Asian Forestry Network, 118-138.

Sikor, T. 2001 The allocation of forestry land in Vietnam: did it cause the expansion of forests in the northwest? Forest Policy and Economics 2: 1-11.

Sikor, T. and Apel, U. 1998 The possibilities for community forestry in Vietnam. Asia Forest Network Working Paper Series. Asia Forest Network, Santa Barbara, CA, USA.

Sunderlin, W.D. and Huynh, T.B 2005 Poverty alleviation and forests in Vietnam, CIFOR, Bogor, Indonesia.

Swallow, B., Leimona, B., Yatich, T., Velarde, S.J. and Puttaswamaiah, S. 2007 The conditions for effective mechanisms of compensation and rewards for environmental services: CES scoping study. Issue Paper No. 3. ICRAF Working Paper No. 38. World Agroforestry Centre, Nairobi, Kenya.

Swallow, B., Nguyen, T.L.H., Nguyen, V.H., Thai, P.T., Dao, N.N., Hoang, M.H., Pham, T.T. 2008 Understanding the Voice of the Poor- Participatory Poverty Analysis with Environment Focus, United Nation Development Program and Ministry of Natural Resources and Environment of Vietnam, Hanoi.

Swan, S. 2008 A rapid review of the enabling environment and existing examples of collaborative special-use forest management in Vietnam. WWF, Hanoi, Vietnam.

Tebtebba 2010 Indigenous people, forest \& REDD plus, state of forests, policy environment and ways forward. Tebtebba,Baguio City, Philippines.

Thomas, D., Hoang, M.H., Pham, T.T., Dang, N.A., Bui, D.T., Nguyen, L.H. and Estévez, P.R. 2008 Synthesize and analyze existing information on poverty environment linkages and identify priority knowledge gaps and define a work plan for the main study. United Nation Development Program and Ministry of Natural Resources and Environment of Vietnam, Hanoi, Vietnam. 
To, D.M. and Vu, H.T. 2000 Tong quan ve Chu rung va Loi ich cua Chu rung trong Kinh doanh Rung trong o Vietnam. (Overview of Benefi ts of Forest Owners and Forest Plantations in Vietnam.) Vu chinh sach $\mathrm{NN}$ va PTNT. Vietnam: MARD.

TRAFFIC 2008 What's driving the wildlife trade? A review of expert opinion on economic and social drivers of the wildlife trade and trade control efforts in Cambodia, Indonesia, Lao PDR and Vietnam. East Asia and Pacific Region Sustainable Development Discussion Papers. East Asia and Pacific Region Sustainable Development Department, World Bank, Washington, DC.

Tran, N.T. 2000 Forest Land Allocation:

A Prerequisite for Community Forest Management. Paper presented at the Workshop on "Sustainable Rural Development in the Southeast Asian Mountainous Region." Hanoi, Vietnam: EC, SIDA, GTZ.

United Nations Collaborative Programme on Reducing Emissions from Deforestation and Forest Degradation in Developing Countries (UN-REDD) 2008 Document of UN-REDD Vietnam. Outlines of general program. UNREDD, Hanoi, Vietnam.

United Nations Collaborative Programme on Reducing Emissions from Deforestation and Forest Degradation in Developing Countries (UN-REDD) 2009 Detailed program outline of UN-REDD program. Government of Vietnam, UN-REDD, Hanoi, Vietnam.

United Nations Collaborative Programme on Reducing Emissions from Deforestation and Forest Degradation in Developing Countries (UN-REDD) and Ministry of Agriculture and Rural Development (MARD) 2010 Design of a REDD-compliant benefit distribution system. UN-REDD and MARD, Hanoi, Vietnam.

United Nations Economic and Social Commission for Asia and the Pacific (UNESCAP) 2003 The environment-poverty nexus revisited: linkages and policy options. Economic and Social Survey of Asia and Pacific 2003.

Un, K. 2007 Department of Political Science Northern Illinois University. Vietnam at the Crossroads: the Modern Political Economym, Available at: http://www.niu. edu/cseas/outreach/pdfs/vietnamxroads.pdf [10 October 2011].
USAID 2011 REDD+ and carbon rights: lessons from the field property rights and resource governance project (PRRGP). Working paper. USAID, US.

van Noordwijk, M., Agus, F., Dewi, S., Ekadinata, A., Tata, H.L., Suyanto, S., Galudra, G. and Pradhan, U.P. 2010 Opportunities for reducing emissions from all land uses in Indonesia: policy analysis and case studies. World Agroforestry Centre, SEA Regional Office, Bogor, Indonesia.

Vietnam Custom Department. 2010 Report on imported and exported timbers, Government of Vietnam, Hanoi, Vietnam.

VNFOREST 2011 Viet Nam forestry: Introduction of forests and forest sector of Viet Nam. Available at: http://vietnamforestry. org.vn/mediastore/fsspco/2011/07/11/ ForestryOfVietNam_2011_EN_Version15.pdf [2 February 2012].

Vo, Q. 2002 Environmental overview of Vietnam uplands in the last ten years: Current status and arising issues. In Sustainable development in Vietnam upland areas: A Look at the Last 10 years and arising issues, Le Trong Cuc, Chu Huu Quy (eds), Hanoi: Agricultural Publishing House.

Vu, H.T. 2001 Analysis and assessment of the implementation of forest management policy and institution at 5 provinces under the Vietnam Sweden Mountainous Rural Development Programme. Mountainous Rural Development Programme and Ministry for Agriculture and Rural Development, Hanoi, Vietnam.

Vu, QV. 2009 'Vietnam's Economic Crisis: Policy Follies and the Role of State-Owned Conglomerates', Southeast Asian Affairs 2009, Singapore: ISEAS, pp. 389-417.

Vu, T. 2011 Để ngành chế biến gỗ phát triển bền vững. Báo điện tử chính phủ nước Cộng hòa Xã hội chủ nghĩa Việt Nam (Towards sustainable timber processing). Available at: http:// baodientu.chinhphu.vn/Home/De-nganh-chebien-go-phat-trien-ben-vung/20113/67995.vgp. [25 February 2012].

Vu, T.P., Vu, T.D., Pham, M.C., Vu, T.M.L., Nguyen, V.X. and Vo, D.H. 2011 Report on Vietnam profile development for measurement and monitoring for REDD implementation. CIFOR, Bogor, Indonesia. 
Wertz-Kanounnikoff, S. and Kongphan-Apirak, M. 2008 Drivers of land-use change and deforestation in Southeast Asia and the role of 'payments for environmental services (PES)' schemes. Background paper for the IIEDWRI-CIFOR project 'Compensation and incentives for the maintenance of ecosystem services: a review of current knowledge and the implications for the Norwegian Climate Forestry Initiative'. CIFOR, Bogor, Indonesia.

World Bank 1990 Vietnam Stabilization and Structural Reforms. An Economic Report. Hanoi: World Bank.

World Bank 2003 State forest enterprise reform in Vietnam: unlocking the potential for commercial wood growing. World Bank, Washington, DC.

World Bank 2009 Vietnam Development Report 2010: Modern Institutions. Hanoi: The World Bank in Vietnam.

\section{Laws and regulations cited}

Circular No. 34/2009/TT-BNNPTNT dated 10 June 2009 of the Ministry of Agriculture and Rural Development on criteria for forest identification and classification.

Decision No. 39 of the Minister of MARD dated 7 January 2011 on establishment of National REDD+ Steering Committee.

Decision No. 39/QĐ-BNN-TCCB dated 7 January 2011 issued by the Ministry of Agriculture and Rural Development on establishment of the Steering Committee for implementation of the 'Reducing emissions from deforestation and forest degradation, and the role of conservation, sustainable management of forests and enhancement of forest carbon stocks in developing countries (REDD+)' in Vietnam.

Decision No. 100/2007/QD-TTg on revision and amendment of some articles of Decision 661/QD-TTg dated 29 July 1998 on objectives, tasks, policies, and implementation arrangements of the 5 Million Hectare Reforestation Programme, on 6 July 2007.

Decision No. 147/2007/QD-TTg dated 10 September 2007 on a number of policies for development of production forests in the 2007-2015 period.
Decision No. 158/2008/QĐ-TTg dated 2 December 2008 issued by the Prime Minister on approval of the National Target Program for responding to climate change.

Decision No. 178/2001/QĐ-TTg dated 12 November 2001 issued by the Prime Minister on the beneficial rights and obligations of households and individuals allocated, leased and contracted forest and forest land.

Decision No. 327 CT of 15 September 1992 on policies for the use of bare land, denuded hills, forests, alluvial flats and water bodies.

Decision No. 380/QD-TTg dated 10 April 2008 by the Prime Minister on piloting payment for environmental forestry services.

Decision No. 661/QD-TTg dated 29 July 1998 issued by the Prime Minister on objectives, tasks, policies and organization for the establishment of the Five Million Hectare Reforestation Programme.

Decision No. 750/QD-TTg dated 3 June 2009, approving the planning on development of rubber trees up to 2015 , with a vision toward 2020.

Decision No. 2730/QD-BNNKHCN dated 5 September 2008 issued by the Ministry of Agriculture and Rural Development to approve 'Action Plan Framework on climate change adaptation and mitigation of the agriculture and rural development sector in period 2008-2020'.

Decree No. 02/1994/NĐ-CP dated 15 January 1994 issued by the Government of Vietnam on enforcing provisions on forest land allocation to organisations, households.

Decree No. 04/2010/QĐ-TTg dated 25 January 2010 issued by the Government of Vietnam on the functions and responsibilities and organisational structure of General Department of Forestry (VNFOREST) under the Ministry of Agriculture and Rural Development.

Decree No. 17/HĐBT dated 17 January 1992 issued by the Ministerial Council guiding the implementation of the Forest Protection and Development Law.

Decree No. 23/2006/NĐ-CP dated 3 March 2006 issued by the Government on the compliance of the Law on Forest Development and Protection. 
Decree No. 50/2010/NĐ-CP dated 14 May 2010 issued by the Government of Vietnam on detailed provisions and guidelines on the implementation of several articles of the Law on Tax on Natural Resources.

Decree No. 60/2008/NĐ-CP dated 9 May 2008 issued by the Government of Vietnam on the provision of the functions, tasks, power and organizational structure of CEMA.

Decree No. 99/2010/NĐ-CP dated 24 September 2010 issued by the Government on PES policy.

Decree No. 163/1999/NĐ-CP dated 16

November 1999 issued by the Government of Vietnam on forest land allocation and lease to organisations, households.

Law No. 01/2002/QH11 dated 16 December 2002 of the National Assembly of Vietnam on Law on National Budget.

Law No. 13/2003/QH11 dated 10 December 2003 of the National Assembly of Vietnam on Land Law 2003.

Law No. 16/2003/QH11 dated 26 November 2003 of the National Assembly of Vietnam on Construction Law.
Law No. 26/2004/QH11 dated 24 June 2004 of the National Assembly of Vietnam on Law on Complaint and Petition.

Law No. 29/2004/QH11 dated 14 December 2004 of the National Assembly of Vietnam on Law on Forest Protection and Development.

Law No. 45/2009/QH12 dated 4 December 2009 of the National Assembly of Vietnam on Law on Taxation of Natural Resources.

Letter No. 282/VPCO-QHQT dated 13 January 2011 issued by The Government Office: Official report from COP16 và CMP6 in Cancun (Mexico).

Ordinance No. 34/2007/PL-UBTVQH dated 20 April 2007 of the National Assembly of Vietnam on grassroots democracy at commune, ward levels.

Ordinance No. 38/2001/PL-UBTVQH10 dated 28 August 2001 of the National Assembly of Vietnam on fees.

Resolution No. 30a/2008/NQ-CP dated 27 December 2008 of the Government of Vietnam on the support programme for poverty reduction in 61 poor districts. 


CIFOR Occasional Papers contain research results that are significant to tropical forestry. The content is peer reviewed internally and externally.

Since 2009, CIFOR has implemented the Global Comparative Study of REDD+ in 9 countries: Bolivia, Brazil, Peru, Cameroon, DRC, Tanzania, Indonesia, Nepal and Vietnam. Partial analysis is undertaken in PNG, Mozambique and Burkina Faso. In analysing national REDD+ policy arenas and emerging strategies, researchers have developed five areas of work for each country. These include a country profile, media analysis, policy network analysis, policy content analysis and a fifth area of specific policy studies, to be determined by emerging research results.

This report discusses the political, economic and social opportunities and constraints that will influence the design and implementation of REDD+ in Vietnam. In particular, four major direct drivers (land conversion for agriculture; infrastructure development; logging (illegal and legal); forest fire) and three indirect drivers (pressure of population growth and migration; the state's weak forest management capacity; the limited funding available for forest protection) of deforestation and degradation in Vietnam are discussed, along with their implications for REDD+. These drivers and their impacts vary from region to region, and change over time - no 'one-size-fitsall' formula will function across the whole of Vietnam. The report also examines the lessons learnt from various forestry and economic development policies and programmes and suggests how a future REDD+ mechanism can overcome the major challenges, which include limited funding for forest protection, weak local governance capacity, poor vertical and horizontal coordination, low involvement of the poor, women and indigenous groups, low economic returns, elite capture of land and benefits, and corruption. The report suggests that if REDD+ is to succeed, it must be participatory, that is, all players are given fair and ample opportunity to be part of the programme (particularly those with the least resources or the greatest economic disenfranchisement); transparent, that is, all players can trace how the programme is administered, including the distribution of benefits; and well-monitored, to ensure that the programme is conducted such that it meets its overarching objectives and guidelines. The success of REDD+ will also require that it take a pro-poor and pro-gender equity approach. 